\title{
PERFIL BIOGRÁFICO DEL CANONISTA JUAN JOSEF ALFRANCA Y CASTELLOTE (1754-1817), RECTOR DEL COLEGIO DE BOLONIA
}

\author{
POR \\ Antonio Astorgano Abajo \\ Instituto «Xavier María de Munibe» de Estudios del Siglo XVIII en el País Vasco
}

\begin{abstract}
RESUMEN
Juan José Alfranca y Castellote (Zaragoza, 8.III.54 - ¿Cuevas de Cañart? [Teruel], 1817), de origen infanzón, doctor en Cánones por las universidades de Zaragoza y Bolonia, fue sucesivamente, colegial y rector del Colegio de San Clemente de Españoles de Bolonia (1780-1788), alcalde del crimen de la Audiencia de Sevilla, oidor y uno de los fundadores de la Real Audiencia de Extremadura (1791) y canónigo doctoral y gobernador eclesiástico de la diócesis de Teruel durante la ocupación francesa (1812).

En el presente trabajo se ponen de relieve las etapas de su trayectoria vital, así como los rasgos de su personalidad, caracterizada por su rectitud y profundos conocimientos jurídicos, y por su actitud reformista e ilustrada, como puso de manifiesto en el Interrogatorio del Partido de Llerena (1791).
\end{abstract}

PALABRAS ClAVE: Juan José Alfranca y Castellote, Llerena, Audiencia de Cáceres, Obispado de Teruel, Colegio de San Clemente de Bolonia.

\section{BIOGRAPHICAL PROFILE OF THE CANONIST \\ JUAN JOSE ALFRANCA Y CASTELLOTE 1754-1817), RECTOR OF THE COLLEGE OF BOLOGNA}

\author{
ABSTRACT \\ Juan Jose Alfranca y Castellote (Zaragoza, 8.III.1754 - Cuevas de Cañart \\ [Teruel], 1817) of nobleman origin, doctor in canon laws by the universities of
}


Zaragoza and Bolonia, wassuccesfully, schoolboy and rector of Saint Clement school for Spaniards in Bolonia $(1780,1788)$, Mayor of crime in the courthouse of Seville, listener and one of the foundersof the Royal Courthouse of Extremadura (1791), and doctoral canon and then ecclesiastical governor of the Teruel diocese during the French invasion (1812). In this essay, the stages of his vital road are highlighted, as well as the features of his personality which are characterized by his uprightness and deep law knowledge and by his reformist and well educated atitude, as he made clear in the cross-examination to the Llerena Perty (1791).

KEY WORDS: Juan Jose Alfranca y Castellote, Llerena, Caceres Courthouse, Teruel Bishopric, School of Saint Clement of Bolonia.

Recibido/Received 05-03-2008

Aceptado/Accepted 30-04-2008

En numerosas ocasiones nos hemos topado con la figura del aragonés Juan José Alfranca, en especial cuando estudiábamos la colaboración de su estrictamente contemporáneo Juan Meléndez Valdés con la Sociedad Económica Aragonesa, y sus relaciones con el jesuita Vicente Requeno y con el inquisidor Nicolás Rodríguez Laso, cuyo hermano Simón Rodríguez Laso, fue el sucesor de Alfranca en el Colegio de San Clemente de Bolonia (1788)1. Después hemos leído el amplio y concienzudo informe y el entusiasmo con que llevó a acabo la «visita» del Partido de Llerena (1791), sin duda el mejor elaborado de los «Partidos», cuando fue nombrado para instaurar la recién creada Real Audiencia de Extremadura.

Por las actas de la Real Sociedad Económica Aragonesa de Amigos del País, nos consta que Arias Mon, oidor de la Real Audiencia de Zaragoza y director de la Real Sociedad Económica Aragonesa de Amigos del País, y Alfranca, rector del Colegio de Españoles de Bolonia, se conocían, al menos desde 1786, pues fue intermediario entre el ex-jesuita Vicente Requeno y la Aragonesa.

\footnotetext{
${ }^{1}$ Algunos trabajos nuestros sobre estos personajes son: «Juan Meléndez Valdés en la Real Sociedad Económica Aragonesa», Revista de Estudios Extremeños, Tomo LI, número I, Enero-Abril, 1995 , pp. 103-175; «Las referencias aragonesas del Discurso de apertura de la Real Audiencia de Extremadura», Revista de Estudios Extremeños, Tomo LIII, número I, Enero-Abril, 1997, pp. 75-155; «El abate Vicente Requeno y Vives (1743-1811) en la Real Sociedad Económica Aragonesa (1798-1801)», Rolde. Revista de cultura aragonesa, $\mathrm{n} .{ }^{\circ}$ 85-86 (julio-diciembre de 1998), Año vigésimosegundo, Zaragoza, 1998, pp. 56-73; «La personalidad del ilustrado Don Nicolás Rodríguez Laso (1747-1820), inquisidor de Barcelona y Valencia», Revista de la Inquisición de la Universidad Complutense, n. ${ }^{\circ} 8$ (año 1999), pp. 119-190; «El Fiscal Inquisidor don Nicolás Rodríguez Laso en Barcelona (1783-1794)», Boletín de la Real Academia de Buenas Letras de Barcelona, vol. XLVII, 1999-2000, pp. 197-276; «El París del verano de 1788 a través del Diario del inquisidor Rodríguez Laso», Trienio. Revista de Ilustración y Liberalismo. n. ${ }^{\circ}$ 40, Madrid, 2002, pp. 5-42. Nicolás RoDRíGUEZ LASO, Diario del viage a Francia e Italia (1788), Zaragoza, Institución Fernando el Católico / Real Sociedad Económica Aragonesa de Amigos del País, 2006. Edición, prólogo y notas de Antonio Astorgano Abajo.

Hispania Sacra, LXI

123, enero-junio 2009, 279-352, ISSN: 0018-215-X
} 
Hasta ahora no hemos encontrado perfilada la figura del oidor Alfranca, quizá el mejor jurista de los diez magistrados, fundadores de la Audiencia de Extremadura. Eran un regente, cuatro oidores encargados de los asuntos civiles, cuatro alcaldes del crimen y un fiscal único para lo civil y lo criminal. Como muestra del desconocimiento sobre Alfranca, valga lo que escribe Salvador Rodríguez Becerra, editor moderno del Interrogatorio de Llerena. Nos esboza un acertado retrato del Alfranca, oidor-visitador, pero confiesa que de sus antecedentes biográficos sólo puede anotar los que se derivan de los datos internos del propio informe del Interrogatorio. Estos, al no estar contextualizados, evidentemente, pueden llevar a errores:

«El oidor, del que tenemos pocos datos salvo los que se desprenden de su propio informe, pues no hemos tenido acceso a la Relación de méritos que presentaban los funcionarios aspirantes a cargos de relevancia, muy probablemente había ejercido cargos de justicia y/o gobierno en algunos otros territorios de la corona posiblemente en Nápoles...».

Estamos seguros de que si en el Interrogatorio, cuyo informe se entregó al Real Acuerdo el 17 de diciembre de 1791, se hubiese aludido al paso de Alfranca por la Audiencia de Sevilla, hoy contaríamos con un magnífico estudio sobre los dos años en que Alfranca fue fiscal del crimen en esa ciudad (1789-1790), lugar de residencia de Rodríguez Becerra. Tendríamos un magnífico eslabón para tejer la biografía del canonista aragonés, que de eso se trata. Con esta finalidad redactamos el presente trabajo, basándonos fundamentalmente en los datos de Antonio Pérez Martín (1979) y en el estudio del P. Miguel Batllori (1981); en los archivos citados en las fuentes.

FAmilia de Alfranca, infancia y estudios DE Alfranca en España (1754-1774)

En primer lugar, para que no quede duda sobre su origen y profundas raíces aragonesas, insertamos el acta de bautismo:

«En ocho de marzo de 1754, el doctor don Manuel Panillo, vicario, bautizó en la Iglesia de Santa María Magdalena solemnemente a Juan, José, Vicente, Fidel, Benito, nacido el mismo día, hijo de don Salvador Alfranca, natural de Zaragoza, y de doña Josepha Castellote, natural de las Cuevas [de Cañart] ${ }^{2}$, cónyuges. Padrino: don Joaquín Langa» ${ }^{3}$.

\footnotetext{
2 Cuevas de Cañart, aldea cercana a la villa de Castellote, a 23 kms. de Teruel.

${ }^{3}$ Archivo Diocesano de Zaragoza (ADZ), Libro de Bautizos de la Parroquia de la Magdalena desde el año 1724 al de 1761 , Tomo 6..$^{\circ}$, fol. $264 \mathrm{v}$.
} 
Nació en la Calle Mayor de Zaragoza, pues en las Listas de cumplimiento Pascual de 1753 (Parroquia de Santa María Magdalena) en dicha calle aparece el matrimonio formado por don Salvador Alfranca y doña Josepha Castellote, con otras tres personas, presumiblemente criados. Sólo le hemos registrado un único hermano varón, Salvador Mariano, dos años menor, nacido el 18 de julio de $1756^{4}$ y fallecido al mes siguiente, el 16 de agosto $^{5}$.

En los años sucesivos desaparece la familia Alfranca de las Listas, porque se había trasladado a la vecina Parroquia de San Nicolás de Bari, en cuyo Libro de los confesados y comulgados podemos seguir la estructura y evolución de la familia Alfranca, residente en la casa número 159 de la calle Gavín (todavía existente). La primera vez que la familia aparece en esta calle es en la lista de cumplimiento pascual de 1759: «Calle Gavín. Casa Alfranca. Don Salvador, amo; Doña Josefa Castellote, su mujer, don Joaquín Langa, Juan Soldevilla, maestro, Manuel Correas, criado, Manuel López, Pedro Navas, criado» ${ }^{6}$. En esa casa morirá el padre en 1787 y la madre diez años después (1797).

Era una casa de las mejores del barrio, según el catastro de $1766^{7}$. Pagaba una elevada renta de 56 libras anuales. En la parroquia no había ninguna casa arrendada por un particular que pagase de renta más que la que habitaba D. Salvador Alfranca.

El padre, don Salvador Joseph de Alfranca y Aramburu, fue abogado hasta el final de su vida y, durante muchos años, catedrático de Prima de Cánones de la Universidad de Zaragoza ${ }^{8}$.

${ }^{4}$ ADZ, Libro de Bautizos de la Paroquia de la Magdalena desde el año 1724 al de 1761, Tomo 6., fol. 289v.

5 ADZ, Libro de Difuntos de la Parroquia de la Magdalena desde el año 1724 al de 1761, Tomo 5., fol. 168 .

${ }^{6}$ ADZ, Parroquia de San Nicolás de Bari. Libro de confesados y comulgados (desde 1738), f. 71v.

7 «Calle de Gavín, acera izquierda entrando por la calle del Sepulcro. Casa 50. Casa de mosén Jerónimo Porroche, beneficiado de la Villa de Quinto de Ebro, confronta con casa del capítulo de San Miguel, y la siguiente [casa número 51, casa también propiedad de don Jerónimo Porroche]. Su arriendo 56 libras anuales. Vive don Salvador Alfranca. Abogado». Archivo del Ayuntamiento de Zaragoza, Catastro Zaragoza 1766, caja 7915, expediente 2/4, fol. 55r. Parroquia de San Nicolás de Bari.

${ }^{8}$ De su ejercicio de la abogacía conservamos algunos dictámenes de don Salvador Joseph de Alfranca y Aramburu, como los rotulados:-Por el Santo Hospital Real y General de Nra. Sra. de Gracia de esta Ciudad. En el Pleyto de aprehension a instancia de Don Carlos Cortés, de Bienes en la misma de Don Lucas de Ainsa,. .. (1747).

- Por Doña Maria Theresa Ximénez de Urrea, viuda, y vecina de la Ciudad de Valencia,. .. Contra Don Diego de Noriega y Albarado,... Sobre que le restituya, y dexe libres los bienes con sus frutos pertenecientes à ciertos Vínculos,. .. (1769). Al parecer redactado conjuntamente con don Manuel Bellostas.

- Por Doña Maria Theresa Ximénez de Urrea,. .. En el pleyto, que en grado de revista sigue con el Marqués de Hermosilla,. .. Sobre tener limitada la viudedad el expressado. .. (1770).

Hispania Sacra, LXI

123, enero-junio 2009, 279-352, ISSN: 0018-215-X 
En la «Lista del Colegio de Abogados de Zaragoza de 1772 que en la actualidad hay dentro y fuera de Zaragoza por su antigüedad», en dicho año, sobre un total de 82 colegiados, el padre de Juan José Alfranca, don Salvador, «catedrático de prima de cánones», ocupa el cuarto lugar por su veteranía. En la lista de abogados de 1786 don Salvador aparece con el número uno del escalafón y se dice que vive en la calle de Gavín, número 159, el que hemos visto en la Listas de Cumplimiento Pascual aunque no está entre los que habían sido decanos. En la lista de 1787 todavía aparece con el número $1^{\circ}$ entre un total de 87 colegiados, pero ya no consta en la lista de 1788 , pues había muerto el año anterior ${ }^{9}$.

En 1761 la familia estaba compuesta por don Salvador Alfranca, «amo»; doña Josefa Castellote, «su mujer»; doña Joaquina Alfranca, «su hija», don Joaquín Longa «tío materno», Juan Soldevilla, Antonio Soldevilla, Florentina Sesé, Sebastián Polo e Inocencia Saura. En los años sucesivos aparecerá la misma estructura de la familia, es decir, el matrimonio y los hijos más algún pariente y alrededor de cuatro criados, generalmente dos criadas y dos criados, los cuales suelen variar en años sucesivos. En la familia solía haber algún estudiante, con cierto grado de parentesco, suponemos que con función de instructor. Por ejemplo, en 1770 encontramos al estudiante Clemente Tarazona. Juan José Alfranca aparece comulgando por primera vez en la lista de 1765, es decir, cuando tenía once años.

La estructura familiar se ve alterada en 1773 con la incorporación del yerno, el abogado de los Reales Consejos, don José Broto (uno de los albaceas testamentarios en 1793 del célebre canónigo Ramón Pignatelli), lo cual supone que entre 1772 y 1773 se había casado con Joaquina Alfranca. Lo curioso es que en 1774 José Broto viene definido como «casero». Esta es la última lista de cumplimiento pascual en la que figura Juan José Alfranca, el cual poco después emprende viaje hacia Bolonia, para estudiar en el Colegio de San Clemente.

En efecto, la única hermana de Juan José Alfranca, María del Pilar Joaquina, se casó en Zaragoza el 16 de agosto de 1772 con el doctor don José Broto, «mancebo, abogado de los Reales Consejos, hijo de don José y Doña Orosia Comas, natural del lugar de Abanies, diócesis de Huesca, residente en Zaragoza y parroquia de San Gil»10. La capitulación matrimonial de su hermana, celebrada el 13 de agosto de 1772 ante el notario Antonio Bernués, tres días antes de celebrarse el matrimonio, pone de manifiesto que fue una boda entre infanzones. D. Salvador José de Alfranca, infanzón, «ciudadano de esta ciudad de Zaragoza, catedrático de prima de cánones de la universidad literaria de la misma, fiscal del tribunal de Cruzada y demás de Gracias, que reside en ella, abogado de la Real Audiencia y

\footnotetext{
${ }^{9}$ Archivos del Colegio de Abogados de Zaragoza (ACAZ), Listas del colegio de abogados de Zaragoza desde el año 1772 a 1839.

${ }_{10}$ ADZ, Parroquia de San Nicolás de Bari. Libro de casados (año 1738-1786), ff. 179v-180r.
} 
demás tribunales de éste dicho Reino de Aragón, y Dña. Josefa Castellote y Langa, cónyuges, domiciliados en la misma ciudad, doña María del Pilar Joaquina de Alfranca y Castellote, doncella, su hija legítima y natural, don José de Alfranca, presbítero, racionero de mensa del Santo Metropolitano templo del Salvador de la presente ciudad, [tío]» dotan a Joaquina magníficamente, pues se describen 21 parcelas de fértiles tierras de regadío concentradas en la vega de Villamayor, barrio de Zaragoza, actualmente en proceso de segregación ${ }^{11}$.

Pero el matrimonio sólo duró tres años, pues el día 5 de diciembre del año 1775, falleció Joaquina, habiendo hecho testamento el mismo día en favor de Juan José, que quedaba como único y universal heredero de la familia AlfrancaCastellote ${ }^{12}$.

En la lista de 1776 hay nueva modificación en la estructura de la familia, puesto que falta la hija Joaquina, aunque su viudo, D. José Broto, continúa viviendo en la casa, en la que permaneció hasta 1781. Años más tarde volverá a casarse, lo cual no será obstáculo para que don Salvador lo continúe llamando «yerno» y se acuerde de él en su testamento en 1787. En 1788 la familia Alfranca vuelve a sufrir una alteración importante, porque desaparece «el amo», don Salvador, fallecido el 16 de marzo de 1787. Está compuesta por Dña. Josefa Castellote, «ama viuda», don Matías Alfranca, «estudiante», don José Sesé «estudiante» y dos criadas: Josefa López y Manuela Braulio.

La familia entra en decadencia con la muerte del patriarca. Don Salvador, «abogado y marido de doña Josefa Castellote», habiendo hecho testamento el 12 de marzo de 1787 ante don Nicolás Bernués, nombra heredera a su mujer, según el acta de defunción ${ }^{13}$. Sin embargo en el testamento notarial deja por parte y derecho de legítima herencia «en dichos mis bienes y hacienda al doctor don Juan José Alfranca y Castellote, mi hijo y de la citada Dña. Josefa Castellote, rector del Colegio Real y Mayor de Españoles de San Clemente de Bolonia». Juan José, nombrado alcalde del crimen de la Audiencia de Sevilla, reside de septiembre de 1788 a enero de 1789 en Zaragoza, con su madre, después de casi catorce años de separación.

Cuatro años más tarde, Doña Josefa Castellote otorgó testamento el 20 de agosto de 1791 ante el mismo notario, poco tiempo después de llegar Juan José a Cáceres, nombrando «heredero de todos mis bienes y hacienda a don Juan José Alfranca y Castellote, mi hijo, del Consejo de su majestad y su oidor de la Real Audiencia de Cáceres» ${ }^{14}$.

${ }^{11}$ Archivo Histórico de Protocolos de Zaragoza (AHPZ), Notario Antonio Bernués, Legajo 5744. Año 1772, ff. 516r-520r.

12 ADZ, Parroquia de San Nicolás de Bari. Libro de muertos (1738-1786). Año 1775, f. 278r.

${ }_{13} \mathrm{ADZ}$, Cinco libros de la parroquial de San Nicolás de Bari, que empieza en el año 1787 y fina en el año 1851, f. 390v.

${ }^{14}$ AHPZ, Notario Nicolás Bernués, protocolo 5672, año 1791, ff. 401r-402r. 
Casi nueve años se mantiene esta misma situación, claramente decadente, de la familia, compuesta por la ama viuda más un estudiante o clérigo como Don Clemente Tarazona, más el servicio de un criado y dos criadas, hasta que en la lista de 1797 la casa número 159 de la calle Gavín «está vacante». En la de 1798 ya está ocupada por otra familia, la de don Domingo Muñoz.

La madre falleció casi seis años después de otorgar el testamento citado, el 3 de enero del año de 1797 y «dejó heredero a su hijo don Juan Alfranca y Castellote, oidor en la Real Audiencia de Cáceres» ${ }^{15}$. Vemos que Juan José no tuvo el consuelo de asistir en sus últimos momentos ni a su padre ni a su madre. Cuando fallece ésta, Juan José era hijo único, según confiesa en una compraventa de una parte de los bienes de la herencia materna en 1812: «me pertenecen por herencia de mi difunta madre, doña Josefa Castellote, como su hijo único que era al tiempo de su fallecimiento» ${ }^{16}$.

Juan José era sólo tres días mayor que el poeta Meléndez Valdés. Los dos nacieron en marzo de 1754, aunque el aragonés fue mucho más precoz en los estudios, pues alcanzó el doctorado en Leyes, cuando el poeta extremeño estaba en el primer curso. Antes de ingresar en el Colegio de San Clemente, como se indica en la Certificación de sus méritos, presentada para el ingreso, tenía 8 años de estudios mayores: 1 de Filosofía en Huesca y 7 de Jurisprudencia en Zaragoza; se graduó de bachiller el 4 de enero de 1770 y de licenciado y doctor en Derecho (1773) en Zaragoza, siendo sustituto de la cátedra de prima de Derecho, miembro de la Academia jurídico-práctica de Zaragoza, etc. Mientras Meléndez flirteaba con los amores anacreónticos, animado por las tertulias salmantinas y el magisterio de José Cadalso, Alfranca se ordenaba de primera tonsura, según se indica en las letras comendaticias del Cabildo zaragozano, presentadas para ingresar en el colegio boloñés.

En los pocos libros académico-administrativos de la Universidad de Zaragoza que sobrevivieron al desastre de la Guerra de la Independencia, encontramos noticias del magnífico estudiante que fue Alfranca. En el llamado vulgarmente De Gestis, rotulado como Registro de gestis que comprehende las resoluciones acordadas por el claustro de la Universidad de Zaragoza que dio principio en 18 de octubre de 1773 y feneció en 18 de octubre de 1774, siendo secretario Mariano de Asín, se recoge una oposición a la cátedra de Sexto en la facultad de Cánones, en la que encontramos a Juan José de Alfranca como un coopositor ${ }^{17}$. Los ejercicios li-

15 ADZ, Parroquia de San Nicolás de Bari. Libro de muertos (1787-1859). Año 1797, f. 404v.

16 Archivo Histórico Provincial de Teruel (AHPT), Protocolos del notario Juan Gabarda, legajo número 438 (año 1812), f. 79. Escritura de venta de varios bienes en Catellote el 23 de mayo de 1812.

17 Biblioteca General de la Universidad de Zaragoza (BUZ), Registro de gestis que comprehende las resoluciones acordadas por el claustro de la Universidad de Zaragoza que dio principio en 18 de octubre de 1773 y feneció en 18 de octubre de 1774, siendo secretario Mariano de Asín, ff. 399r-407v. 
terarios son prácticamente los mismos que adujo al solicitar la beca en el Colegio de Bolonia.

El 2 de agosto de 1774 el rector de la Universidad de Zaragoza, Joaquín Benito Garay, envía al secretario de Consejo de Castilla, don Pedro Escolano de Arrieta, una carta con los «ejercicios literarios» del doctor don Juan José Alfranca y Castellote, que son un resumen académico de los primeros veinte años de vida de nuestro personaje, cuya veracidad hemos podido comprobar, confrontando los respectivos libros académicos de la Universidad de Zaragoza:

«6. El doctor don Juan José de Alfranca y Castellote tiene los títulos, grados y ejercicios literarios siguientes: siete años de estudios mayores en Dialéctica y Jurisprudencia civil y canónica; el primero en que, a más de la asistencia a la cátedra y repaso, defendió, presidido de su maestro, un acto de academias públicas.

Los seis años restantes [1768-1774] de Jurisprudencia civil y canónica en esta universidad literaria de Zaragoza, en que, habiendo concurrido en los cuatro primeros [17681772] a cátedras que previenen los estatutos y a los repasos, y tenido en la sala del claustro un acto de academias públicas, según la costumbre, y haber leído media hora con puntos de 24 de el capítulo que le cupo en suerte, respondido por otra media hora a dos argumentos de dos de los examinadores catedráticos, y a las diferentes preguntas que, por espacio de un cuarto de hora, se le hicieron. Por otro de estos [actos públicos] obtuvo el grado de bachiller en la facultad de cánones [4 de enero de 1770].

En los dos años siguientes [cursos 1771-72 y 1772-73] continuó estos y otros ejercicios literarios y conferencias, presidiendo en la sala del claustro un acto de academias y arguyendo cuando por turno le correspondió. Y en el día 26 de agosto de 1773, habiendo defendido un acto mayor de conclusiones públicas por la mañana y tarde sobre diferentes puntos canónicos en el teatro de dicha universidad, respondiendo a sus argumentos de los catedráticos de ella, y después, leído por una hora con puntos de 24 del capítulo De testamentis, que le sorteó, y, respondido por más de otra a los argumentos y dificultades propuestos por los examinadores, y hechos los demás ejercicios del Estatuto, obtuvo el grado de licenciado, con la calidad de ex toto rigore justitiae, y las demás con que puede conferirse dicho grado, según los Estatutos; y posteriormente, precedido el ejercicio acostumbrado, recibió la borla de doctor con asistencia del rector, regimiento y graduados de todas las facultades, que es la pompa y concurrencia que siempre se acostumbra en semejantes grados, con las mismas calidades arriba dichas, en el teatro mayor de la escuela.

Posteriormente ha repasado por un curso [curso 1773-74] en la facultad de Cánones, por nombramiento del claustro, presidiendo academias y arguyendo en la sala de dicho claustro siempre que le ha tocado el turno.

En este tiempo fue admitido en la Academia jurídico-práctica de dicha ciudad de Zaragoza, de que es su individuo y se ha ejercitado en ella, informando en derecho y determinando las consultas y puntos que le han controvertido en ella, procurando desempeñar los demás ejercicios que se acostumbran a practicar y le han cabido [en suerte], como también los cargos que le han dado, conforme [a] sus Estatutos y el de su secretario, que actualmente [julio de 1774] tiene.

Y finalmente, hallándose vacante la cátedra de Sexto de esta escuela, ha hecho oposición a ella, leyendo una hora con puntos de 24 de el capítulo del Sexto de las Decretales, que le cupo por suerte, respondiendo a dos argumentos de sus coopositores y arguyendo,

Hispania Sacra, LXI

123, enero-junio 2009, 279-352, ISSN: 0018-215-X 
en la misma forma, a éstos dos veces por espacio de media hora cada una, cuyos ejercicios le han sido aprobados por el claustro para suplicar a vuestra majestad la merced de dicha cátedra» 18 .

Esta parece ser la única oposición a cátedras en la participó Alfranca en el año largo que va desde que consiguió lo borla de doctor (agosto de 1773) hasta el invierno de 1775 en que gestiona su beca para ingresar en el Colegio de Españoles de San Clemente de Bolonia.

No aparece como opositor en las varias cátedras de las facultades de Cánones y Leyes que se celebraron durante ese tiempo. Por ejemplo, el mismo día 31 de julio de 1774 el rector informa la cátedra de Código pero no aparece Alfranca, a diferencia de muchos de los opositores que habían participado en la anterior oposición de Sexo' ${ }^{19}$. Lo mismo ocurre el 31 de agosto, cuando se informa la oposición de la cátedra de Instituta (12 opositores) ${ }^{20}$.

Pero Alfranca no estaba perdiendo el tiempo, sino que, una vez conseguido el doctorado permaneció ligado a la facultad de Cánones durante el curso de 1773-1774, como indica el informe del rector, pues en el claustro del 25 de octubre de 1773, celebrado para elegir los repasantes en las facultades de Leyes y Cánones, observamos que el primer repasante nombrado para ésta última es Juan José Alfranca y, también para dicha Facultad, lo es su compañero de curso a lo largo de toda la carrera, el conocido economista don Eugenio Larruga ${ }^{21}$. El claustro concluye con una advertencia a los repasantes: «se acordó se les prevenga a los repasantes no tengan el repaso a hora que impidan la asistencia a la hora de las cátedras» 22 .

Desgraciadamente no podemos seguir con detalle la vida académica de Alfranca porque se han perdido muchos Libros de Gestis de la Universidad de Zaragoza, sobretodo durante los sitios de la Guerra de la Independencia. No existen Libros de gestis del curso 1770 al 1773 y en el libro de 1771 al 1772 no se dice nada de Alfranca.

Por los Libros de Matrículas, sabemos que en el curso 1769-1770, Alfranca, «natural de Zaragoza», se matriculó en segundo curso de Cánones ${ }^{23}$. En el libro del curso siguiente (fol. 89), curso 1770-71, siendo rector don Pablo Castillo

18 BUZ, Registro de gestis. .. 1773, ff. 404r-405r.

19 BUZ, Ibidem, ff. 422-428.

${ }^{20}$ BUZ, Ibidem, ff. 429-432.

${ }^{21}$ BUZ, Ibidem, f. 15.

22 BUZ, Ibidem, f. 15v.

23 BUZ, Rúbrica de las matrículas contenidas en este libro de los cursantes en todas los facultades, que da principio en 18 de octubre de 1769, siendo rector el señor doctor don Ignacio Azpuru y don Mariano de Assín secretario, f. 33. 
Larroy, canónigo de la Santa iglesia de Zaragoza y secretario propietario de ella don Eustaquio Vidal y Latorre, hallamos a Juan José Alfranca matriculado del tercer curso de carrera de Cánones. En el libro del curso 1771-72 (fol. 45), siendo rector don Eugenio Roselló, chantre dignidad en la Santa Iglesia de Zaragoza, encontramos matriculados en el cuarto curso en la misma Facultad a Juan José de Alfranca y a don Eugenio Larruga, ambos de Zaragoza. En el curso siguiente, es decir, en el que empieza el 18 de octubre de 1772 y acaba el 18 de abril de 1773 descubrimos entre los pasantes de Leyes a don Eugenio Larruga, pero Alfranca no parece matriculado en ninguna facultad. Tampoco aparece en el curso que empieza el 18 de octubre de 1773, siendo rector don Joaquín Benito de Garay, canónigo de la Santa Iglesia metropolitana de Zaragoza.

En conclusión, es seguro que Alfranca estudió cuatro cursos en la facultad de cánones entre 1768 y 1772, de la que su padre era catedrático de Prima, aunque del primer año, el que empieza en octubre de 1768 y acaba abril de 1769, sólo nos consta la aprobación y no la matrícula, que bien pudo haberla hecho también en la Facultad de Leyes ${ }^{24}$. Entre sus compañeros de estudios destaca Eugenio Larruga (Zaragoza, 15 de noviembre 1747 - Madrid, 15 de febrero 1803), conocido economista, escritor y viajero ilustrado.

\section{Alfranca en el colegio de San Clemente de Bolonia (1775-1788)}

Conocemos bastante bien esta etapa de la vida de Alfranca, gracias a las informaciones que leemos en la obra de Primo Bertrán Roigé (1979) y en la de Antonio Pérez Martín (1979), además de los imprescindibles estudios de Batllori (1971) y Froldi (1981). En el Colegio de España se conserva su expediente como colegial durante casi quince años (1775-1789), donde pasó por todos los empleos, incluido el de rector.

Alfranca llega a un Colegio que llevaba en crisis más de un siglo, a pesar de las numerosas reformas, que acabarán por poner en tela de juicio su supervivencia. Frodi (1981, pp. 132-134) recuerda que en 1728, el Cardenal Luis Antonio Belluga pensó trasladar el Colegio a Roma, pero los dos únicos colegiales presentes se procuraron la protección del visitador boloñés, el Cardenal Próspero Lambertini, quien, después, cuando en 1740 fue elegido Papa con el nombre de Benedicto XIV, consolidó el resurgimiento de la Institución con el envío de once becarios. Pero el desorden interno se reanudó, de modo que Fernando VI ordenó que el cargo de visitador regio se concediera al canónigo Francisco Pérez Bayer. Dictó éste algunas normas de importancia fundamental, como el

${ }^{24}$ BUZ, Libro de Matrículas de los cursantes en todas las facultades que principió el 18 de octubre de 1770 , f. 98 .

Hispania Sacra, LXI

123, enero-junio 2009, 279-352, ISSN: 0018-215-X 
nombramiento directo del Rector por parte del Soberano. Contra la tradición, el Colegio pasaba, en sustancia, a quedar bajo el pleno control de la Corona, lo cual permitirá, en el clima de regalismo dominante, salvar la institución.

Sólo después de la reforma de Pérez Bayer (1756-1757) nos es posible notar en el Colegio la reanudación de una vida intelectual más empeñada en realidades menos ocasionales y sujeta a módulos menos conformistas. Sin embargo, en el Colegio permanecen las huellas profundas de una tradición que se esfuerza por sobrevivir, contra los apremios de las diversas exigencias de los tiempos y del ambiente que se va transformando 25 .

El 2 de mayo de 1775 se presentó en el Colegio la candidatura y documentos de Alfranca, avalada por el Cabildo de Zaragoza para estudiar Derecho Canónico $^{26}$. Los días 25, 27 y 29 de mayo se examinaron, por tres veces, sus pruebas de limpieza de sangre, y se aprobaron. Fue admitido por el rector Luis Urriola. El tema de su disertación de ingreso fue sobre el capítulo «relatum 5 de autoritate et usu pali» (X 1.8.5). La fecha de su admisión en el Colegio no se indica, pero debió de ser el mismo 29 de mayo o poco después, día en que se aprobaron por tercera vez sus pruebas.

El colegial Antonio Salinas Moñino, sobrino de Floridablanca, al redactar en 1778 la crónica de 1775, escribía:

«Por el mayo y julio de 1775 llegaron a Bolonia los señores don Juan Alfranca, jurista, y don Luis Cascallana, teólogo, presentados para esta Santa Casa, el 1. por el cabildo de la iglesia de Zaragoza, y el $2 .^{\circ}$ por el de Sevilla. Ambos fueron recibidos y puestos en la posesión de sus respectivas becas, presupuestas las diligencias preliminares de presentación, de nombramiento, pruebas y su revista, con la satisfacción de ver agregados al cuerpo respetable de esta comunidad dos sujetos adornados de las cualidades que apetecen nuestros estatutos, y capaces de llenar las altas obligaciones de nuestra beca» 27 .

Podemos seguir su actuación como colegial, año por año, teniendo en cuenta que los cargos colegiales se renovaban por el mes de mayo. Don Juan José de Alfranca y Castellote comenzó muy pronto a sobresalir entre los demás estudiantes.

\footnotetext{
25 R. FROLDI, 1981, p. 143.

${ }^{26}$ La documentación presentada para el ingreso consiste en: 1) Letras presentaticias del Deán y Cabildo zaragozanos a favor de Juan José de Alfranca y Castellote, dadas el 17 de febrero de 1775; 2) Certificación de los méritos de Juan José Alfranca, fechada en Zaragoza el 25 de marzo de 1775; 3) Primeras pruebas de Juan José Alfranca, hechas en Zaragoza el 20 y 23 de marzo de 1775 (incluyen la partida de bautismo y el acta de matrimonio de sus padres). En Lettere, Busta (Legajo) I, n. ${ }^{\circ} 18$ se contienen cuatro documentos de o sobre Juan José Alfranca.

${ }^{27}$ Archivo del Colegio de España de Bolonia (ACEB), De rebus gestis, II, 146r; BATLloRI, 1971, p. 656.
} 
Curso 1776-1777: es nombrado consiliario e historiador o cronista. Para ambos cargos fue elegido el 3 de mayo de $1776^{28}$. Durante este curso, además de redactar la historia del Colegio que le correspondía, escribió la de cursos anteriores. No debe extrañarnos, pues, que el mejor Interrogatorio de la Audiencia de Extremadura (1791) sea el del Partido de Llerena, responsabilidad del oidor Alfranca, incluidos los numerosos «Informes resultativos» en los que da su acertada y fundamentada opinión sobre lo que le han contado o ha visto en los pueblos visitados. Llevaba quince años redactando crónicas e informes en la quisquillosa sociedad boloñesa.

Curso 1777-1778: es consiliario y celario. Para ambos cargos fue elegido el 3 de mayo ${ }^{29}$. Durante este periodo fue encargado para que, junto con el colegial Luis José de Cascallana, recogiera noticias sobre el historiador Juan Ginés de Sepúlveda (1490-1573), tarea que mereció las alabanzas de la Real Academia de la Historia de Madrid. El 29 agosto de 1778 se le da licencia para ir a Roma y Nápoles junto con el colegial Francisco Javier Almonacid. En el curso 17781779 es consiliario y secretario del Colegio (elegido el 11 de julio de 1778).

A lo largo de siete años (1778-1785) fue profesor de Derecho Canónico en la Universidad de Bolonia ${ }^{30}$. Durante su estancia en el Colegio concursó varias veces a cátedras de Derecho Canónico: el 18 de junio de 1778 con el capítulo 1 «de pactis» (X 1.35.1). El 12 de agosto lo hizo con el capítulo 10 «de hereticis» (X 5.7.10) consiguiéndola. Al día siguiente, tuvo un discurso en latín. Según los rótulos universitarios, Alfranca fue lector honorario leyendo, en el curso 17781779 en la segunda hora de la tarde, los siguientes títulos de las Decretales: «de vita et honestate clericorum» (X 3.1), «de clericis conjugatis» (X 3.3) y «de peculio clericorum» (X 3.25); en los restantes cursos explicó las instituciones canónicas ${ }^{31}$. El 14 de julio de 1784 renunció a la cátedra, y se le aceptó, por su calidad de Rector del Colegio ${ }^{32}$.

Curso 1779-1780: es consiliario y secretario. Para ambos cargos fue elegido el 3 de mayo de 1779. En el curso 1780-1781 es consiliario y bibliotecario. Fue sustituido por Luis José de Cascallana al ser elegido rector.

Durante ocho años (1780-1788) es rector interino del Colegio por nombramiento real (5 de septiembre de 1780), en calidad de rector interino, al ausentarse el rector Luis Urriola. Entonces fue nombrado por carta de Floridablanca,

\footnotetext{
${ }^{28}$ ACEB, LD (Liber Decretorum), VI, pp. 286-292; LRG (Liber de rebus gestis), II, f. 210v.

${ }^{29} \mathrm{ACEB}$, Libro de las resoluciones de la Junta de Hacienda, ff. 12r-14r.

30 Umberto DALlaRI, I rotuli, dei lettori legisti ed artisti dello Studio Bolognese dal 1384 al 1799, tomos I-IV, Bologna, 1888-1924. La cita corresponde al vol. III-II, pp. 214, 219, 225, 231, 236, 241, 247.

${ }^{31}$ DALlari, I rotuli, III-II, pp. 214, 219, 225, 231, 236, 241, 247.

32 ACEB, Matriz de los Decretos del Real Colegio Mayor de San Clemente de Bolonia, f. 5r.
} 
por ser el colegial más antiguo. Su salario era de 40 ducados del real erario más la mitad de lo que correspondía a los rectores en propiedad. El 30 de octubre tomó posesión de la Rectoría ${ }^{33}$.

Durante su Rectorado se unió definitivamente al Colegio de España el Colegio Vives al morir su último colegial ${ }^{34}$. Se llevó a la práctica un resurgimiento en los estudios. Alfranca participó en este movimiento con una disertación sobre «Se le leggi sontuarie sono utili o perniciose e in quale specie di Governi sono più o meno ammissibili», y sobre «el Colegio de nuestro insigne colegial Antonio Agustín». Estuvo ausente el 29 de mayo de 1782, sustituyéndole en el cargo el colegial Palomeque. El 8 de octubre de 1783 viaja a Venecia con el Conde del Asalto, sustituyéndole en el cargo Villagómez, sobrino del cardenal Lorenzana.

Permaneció en el empleo hasta el 15 de agosto de 1788; unos meses antes había ido a Roma quedando, como sustituto suyo, Fernando Queipo de Llano. El 18 de agosto de 1788 se arreglaron las cuentas de lo que el Colegio tenía que pagarle como Rector ${ }^{35}$.

Alfranca fue el Rector que admitió a los colegiales Cayetano Moreno, Francisco Granizo, Ignacio Múzquiz, Francisco San Pedro, Fernando Queipo (hijo del conde de Toreno), Francisco Fernández Campomanes (sobrino del célebre fiscal), Wenceslao Argumosa, Rodrigo Sierra y Llanes (sobrino del arzobispo de Sevilla, Marcos Llanes) y Tomás Arias, y al capellán Domingo Cantelli³6.

El 15 de agosto de 1788 Alfranca cesa en su cargo, pues ese día toma posesión su sustituto, Simón Rodríguez Laso, según nos cuenta su hermano Nicolás Rodríguez Laso en el Diario del viaje a Italia, que hizo para acompañar a su hermano. Escribe Nicolás en Bolonia el día 9 de Agosto de 1788: «Se hallaban en el colegio los señores colegiados siguientes ${ }^{37}$ : don Juan Josef Alfranca, natural de Zaragoza, rector interino...» ${ }^{38}$.

Su nombre falta en las listas de colegiales a partir del curso 1789-1790, porque en 1787 había sido nombrado alcalde del crimen en la Audiencia de Sevilla, en atención a su labor como rector del Colegio, sobre todo por la reforma en el

${ }^{33}$ ACEB, De rebus gestis, II, 191r. BATLLORI, 1971, p. 658.

${ }^{34}$ Manuel J. PELÁEZ, «Notas para el estudio histórico-jurídico, a través de su documentación manuscrita, del Colegio Vives de Bolonia (1538-1758), una institución educativa de Alcañiz en la Romagna», Teruel: Revista del Instituto de Estudios Turolenses, n. ${ }^{\circ} 67$ (1982), pp. 61-72.

${ }_{35}$ ACEB, LD, VI, pp. 530, 531-532.

36 ACEB, LA, VI, ff. 146r-v.

37 Según BATLloRi (1971, p. 662), las circunstancias del Colegio en 1787 eran poco apropiadas, pues «sólo quedaban en él el rector Alfranca y tres colegiales: Fernando Queipo de Llano, historiador; Wenceslao Argumosa, bibliotecario, y Rodrigo de Sierra, secretario».

38 Astorgano, 2006a, pp. 298-299. 
plan de estudios. En 1790 pasó a ser oidor de la Audiencia de Cáceres, al mismo tiempo que se le asignaba una pensión eclesiástica para ordenarse de sacerdote (Batllori, 1971, p. 665).

¿Cómo era el Colegio de España que dirigió Alfranca?

En el reinado de Carlos III el Colegio de San Clemente de los Españoles acababa de superar una serie de graves crisis. Protegido por el gobierno de Madrid, iniciaba un período de cierta normalidad y de relativo florecimiento, que durará hasta las guerras de Bonaparte (Batllori 1971).

Este apoyo de las autoridades madrileñas era lógico e interesado, pues, en 1773, cuando la prevención contra los Colegios Mayores y contra sus colegiales hacía ya presagiar su supresión inmediata en la Península, el propio Campomanes obtenía una beca de San Clemente para su sobrino Domingo Fernández Campomanes, a pesar de no tener los veintiún años reglamentarios ${ }^{39}$. En 1776, a raíz de su supresión, el ministro Moñino negoció otra para su sobrino Salinas Moñino. Dado el apoyo que el Colegio de Bolonia había hallado siempre en Floridablanca, «no es extraño que el Colegio celebrase infinito la ocasión de poderle complacer y llenar sus deseos de colocar en él a su digno sobrino» ${ }^{40}$. Escribe el cronista Juan José Alfranca en 1777, reproducido por Batllori ${ }^{41}$ :

\begin{abstract}
«Cuando el Excmo. Señor Don Josef Moñino, conde de Florida-Blanca (al escribir esta historia, primer secretario de Estado de S. M. Católica) pasó por esta ciudad a su ministerio de Roma, con el motivo de haber tratado los colegiales quedó tan prendado de ellos y del Colegio que, no obstante saber muy bien cuán aborrecible se empezaba a hacer el nombre de colegial en nuestra Corte por la inminente destrucción de los Colegios Mayores de España sucedida después de 1776, determinó enviar a este Colegio, y revestir la beca de esta tan antigua e ilustre fundación, a un sobrino suyo llamado Don Antonio Salinas Moñino».
\end{abstract}

Alfranca fomentó el compañerismo entre los colegiales, casi todos alevines de los gobernantes regalistas madrileños, como demuestra el hecho de que en 1784, siendo rector y catedrático de la Universidad de Bolonia, renunciase a su cátedra de cánones en favor del colegial Fernández de Cueto, que regresaba a España, para «que llevase esta distinción» ${ }^{42}$. El espíritu de cuerpo de todos los colegiales mayores se manifestaba también en el empeño con que procuraban la gloria del propio colegio. Alfranca presidió solemnemente la función que se tuvo el 6 de octubre de 1783 para celebrar el nacimiento de los infantes geme-

\footnotetext{
${ }^{39}$ ACEB, De rebus gestis, II, f. 136r, BATLLORI, 1971, p. 648.

40 Ibidem, f. 150v.

${ }^{41}$ BATLlori, 1971, p. 649.

42 ACEB, De rebus gestis, II, f. 219r. Miguel Batllori (1971), p. 647.
} 
los don Carlos y don Felipe, hijos de los príncipes de Asturias. A ella asistieron el capitán general de Cataluña, conde del Asalto, el ministro de España en Bolonia, conde Zambeccari. y los comisarios reales para los ex-jesuitas, don Pedro Laforcada y don Luis Gnecco. Celebró la misa el arzobispo de Bolonia. A la recepción del día de San Clemente, 26 de noviembre, acudió toda la nobleza boloñesa ${ }^{43}$.

Muchos fueron los personajes de importancia que durante la colegiatura o el rectorado de Alfranca visitaron el Colegio, al ir o al volver de Roma, o incluso se hospedaban en él. El cronista Alfranca consigna, en 1779, el paso por el Colegio, a principios de junio, de monseñor Giuseppe Garampi, antiguo archivero pontificio y ahora nuncio en Viena ${ }^{44}$.

Pero simultáneamente el rector Alfranca mantenía buenas relaciones con los jesuitas expulsos, odiados y perseguidos por los políticos madrileños. Ya hemos aludido a la afinidad de la familia Alfranca con el alto clero zaragozano, y veremos a Juan José ordenarse sacerdote, lo cual puede ayudar a explicar los vínculos que el Colegio de Bolonia tuvo con los ex-jesuitas durante su rectorado, examinadas por Batllori en el artículo citado (1791).

El mismo año 1775 en que comenzaba su rectorado don Luis de Urriola, llegaba como colegial el aragonés Juan José de Alfranca, que parece fue el primero en establecer relaciones cordiales y amistosas con algunos ex-jesuitas españoles. Tal vez se debió a anteriores contactos familiares con la Compañía en Aragón, antes del extrañamiento; pero desde 1773 también la actitud de la corte con los exiliados había cambiado: destruida la Compañía de Jesús como orden, ya no eran tan temibles, y, además, sus trabajos y sus publicaciones culturales los hacían beneméritos de su patria lejana (Batllori, 1971, p. 656).

Sabido es que en Bolonia terminaron concentrándose muchos de los jesuitas expulsos (en 1768 una parte de los jesuitas de Nueva España y todos los de la provincia de Castilla, que comprendía Castilla la Vieja, León, Galicia, Asturias, Navarra y las Vascongadas; y allí permanecieron hasta la disolución en 1773, cuando algunos de los residentes en Bolonia se establecieron en otras partes, y a Bolonia acudieron otros, en especial los aragoneses establecidos en Ferrara, en busca de una ciudad más acomodada a sus estudios y predilecciones) y que el Colegio de España, dependiente de los regalistas expulsadores madrileños, no podía recibirlos con buenos ojos. Si nos atuviésemos sólo a la documentación del archivo del Colegio, llegaríamos a la falsa conclusión de que su rector Alfranca y sus colegiales vivieron incomunicados con sus compatriotas exiliados, formando dos grupos sin conexión alguna.

${ }^{43}$ ACEB, De rebus gestis, II, ff. 214r-215r. Miguel BatLlori, 1971, p. 647.

${ }^{44}$ ACEB, De rebus gestis, II, f. 184v. 
En la crónica De rebus gestis no se halla ninguna alusión a ningún exjesuita español residente en Bolonia. Según la documentación del Colegio, sólo dos exjesuitas habrían estado en relación directa con él, y aun sólo por carta, pues no residían habitualmente en Bolonia: El entusiasta apologista de la cultura española, Francisco Xavier Llampillas, enviaba al rector y colegiales de San Clemente el 20 de agosto de 1779, desde Génova, la primera parte de su Saggio apologetico della letteratura spagnuola, con una nota en la que afloran los mismos sentimientos que, también por esas fechas, refleja la respetuosa y sumisa carta que le escribió a Campomanes (su continua apología de la nación española y su ardiente deseo de vindicar el honor de la nación con la obra que le regala) ${ }^{45}$.

El ex-jesuita valenciano don Juan Andrés, en la segunda de sus cartas familiares, del 9 de noviembre de 1785, hacía mención del Colegio de Bolonia, de su archivo y de sus antiguos códices en contraste con la sección moderna de su biblioteca «que podría estar mejor surtida» 46 . En 1804, ultimada ya su gran historia universal de la literatura (Origen, progresos y estado actual de toda Literatura), preparaba su edición de las cartas latinas de Antonio Agustín, y pidió ayuda al Colegio de España, que aparece reflejada en la crónica de dicho año ${ }^{47}$.

Pero por otras fuentes sabemos que el Colegio tuvo otros muchos contactos con varios ex-jesuitas, además de estos con los abates Llampillas y Andrés. Los 63 volúmenes del Diario del padre Manuel Luengo, residente en Bolonia, y los 22 tomos de sus Papeles varios, están llenos de noticias sobre España, recibidas, casi siempre a través de tercera persona, de los colegiales que iban llegando a Bolonia, sobre las relaciones del Colegio con muchos de los varios centenares de ex-jesuitas españoles e hispanoamericanos que residían en Bolonia, y con los varios millares dispersos por otras ciudades. No faltan en ellos comentarios doloridos sobre los avances del regalismo en España, que se reflejaban y se refractaban en el Colegio de España, más directamente sometido a los influjos pistorienses y febronianos. Pero aquí voy a limitarme a dar una visión sumaria de la vida cultural del Colegio de San Clemente de los Españoles desde 1775 hasta 1789, periodo de la estancia del colegial Alfranca en Bolonia, entreverando en ella sus contactos con los exiliados tal como aparecen en otras fuentes documentales de la época.

Las relaciones del Colegio con los ex-jesuitas exiliados no comenzaron con el rectorado de Alfranca, pero entonces se aumentaron y fortalecieron. El primer dato que tenemos de las relaciones del Colegio con los ex-jesuitas es de 1776, primer curso de Alfranca en Bolonia. Luengo narra en su Diario que mu-

\footnotetext{
45 A. Astorgano, 2003b, pp. 278-283.

46 Juan ANDRÉs, Cartas familiares, I, Madrid, 1786, p. 38.

${ }^{47}$ ACEB, De rebus gestis, II, ff. 302r-303r. El decreto del Colegio sobre esta consulta en ACEB, M/III, f. 592v. 
chas de las poesías en varias lenguas, que se repartieron en los festejos por el nombramiento de Floridablanca como primer ministro y luego se publicaron en un opúsculo, fueron compuestas por varios ex-jesuitas. En contra del parecer del recalcitrante Luengo, varios ex-jesuitas colaboraron para suplir las carencias formativas y humanísticas de los colegiales. Entre esos colaboradores estarían el ex-jesuita castellano Esteban de Arteaga, futuro secretario del embajador Azara, y el gran helenista mallorquín Bartolomé Pou ${ }^{48}$, quien por aquellos años había comenzado a ser preceptor particular de letras grecolatinas de algunos colegiales de San Clemente ${ }^{49}$.

Con aprobación del rector Alfranca, muy pronto Pou pasó a ser, de preceptor particular, maestro común de los colegiales de San Clemente. No es que tuviese clases de humanidades en el Colegio, sino que vino a ser el orientador de sus estudios literarios, y, no pudiendo residir en el mismo Colegio porque ello estaba reservado, según los estatutos, a los colegiales y a sus servidores, al menos era invitado a veranear con ellos en la finca de Castenazzo. No era poco el atrevimiento del rector Alfranca al invitar a un ex-jesuita a veranear con todos los honores, según confiesa el mismo Pou, «novus Castenazi rusticator» en el más agradable hospedaje (Batllori, 1971, p. 659).

El rector Alfranca alcanza uno de los momentos de mayor ostentación social en 1783, con motivo del nacimiento de los infantes mellizos Carlos y Felipe, hijos de los príncipes de Asturias, celebrado pomposamente por el Colegio en ese año, como en muchos lugares de la monarquía (recordemos que con este mismo motivo Meléndez compuso su única y premiada obra teatral, Las Bodas de Camacho el Rico). Como se había hecho en 1776, su rector quiso publicar con esa ocasión un manojo de poesías en varias lenguas, que también ahora compusieron algunos exiliados. Se trataba de homenajear a dos inocentes infantes reales, y ni Pedro Cordón, ni Francisco Xavier Peirolón, ni Manuel Lassala, ni Tomás Serrano, ni el mismo Pou tuvieron inconveniente en firmar las composiciones con sus nombres y apellidos; todos los colaboradores eran ex-jesuitas, menos el abate italiano Michele Canevari ${ }^{50}$.

\footnotetext{
48 Institutionum historiae philosophia libri XII. Cfr. ibid., f. 312. Sobre las relaciones de Campomanes con Bartolomé Pou, ver A. Astorgano, 2003b, pp. 287-293.

49 Biblioteca comunale de Forli, autografi Piancastelli. Miguel BATLLORI, «El Colegio de España en Bolonia a fines del siglo XVIII», p. 658.

${ }^{50}$ Es un folleto de XII pp. titulado Poesie varie dall'Almo Real Collegio di S. Clemente di Spagna in occasione del felice avvenimento della nascita dei reali infanti D. Carlo e D. Filippo di Borbon (Bologna, Della Volpe, 1783). En el ACEB, T/I, Pagamenti 177985, f. 118r, a los 17 de octubre de 1783, no se especifican los gastos de la edición, sino sólo: «A spese straordinarie per lo piu occorse in far solennemente cantare messa pontificale e Te Deum in occasione del felice avvenimento della nascita di due infanti figli de'reali principi d'Asturias, come al foglio e ricevute n. ${ }^{\circ} 129$, lire 1143:15:6». Pero los $\mathrm{Li}$ bros de cuentas más completos sólo llegan al mes de abril de 1783 .
} 
Entre el rector Alfranca y el helenista Bartolomé Pou iban consiguiendo ampliar la formación de los colegiales, definidos un tanto despectivamente por Juan Andrés como estudiantes de leyes y cánones (que podían cursar igualmente en España), que vivían de espaldas a las ciencias y aun a la filosofía.

Los últimos años del rectorado de Alfranca estuvieron marcados por un mayor dinamismo académico, al parecer no altruista sino suscitado por los aires amenazantes contra los colegios mayores, evidentes en España. Ciertamente había algún desorden entre los mimados sobrinos de Campomanes, de Moñino, del arzobispo Marcos Llanes, el hijo del conde de Toreno, y otros colegiales ${ }^{51}$, de manera que el embajador en Roma, José Nicolás de Azara, que ejercía cierta vigilancia sobre San Clemente, hizo secuestrar los subsidios a algunos colegiales hasta que hubiesen pagado sus deudas, y con ello se evitó la temida visita (inspección), que, dados los tiempos anticolegiales que corrían, incluso podría acabar en la supresión. A raíz de esta amenazante situación, el rector Alfranca y el Colegio decretaron el 6 de enero de $1786^{52}$ que se tuviesen frecuentes actos públicos de carácter cultural, para estímulo de los colegiales en sus trabajos personales, y para probar a los de fuera de que la holganza no reinaba en el Colegio ${ }^{53}$.

El primer acto público de cierto relumbrón se tuvo el 25 de enero y estuvo dedicado al duque de Parma don Fernando, cuyos representantes en Bolonia presidieron. El propio Argumosa disertó «De legibus antiquioribus in Europae politica retractatis». Y al día siguiente, para contentar a todos los gustos, se tuvo «una Academia de canto y música instrumental» ${ }^{54}$.

Las circunstancias del Colegio en 1787 no eran las más apropiadas para continuar un plan tan ambicioso como el trazado el año anterior: sólo quedaban en él el rector Alfranca y tres colegiales: Fernando Queipo de Llano, historiador; Wenceslao Argumosa, bibliotecario; y Rodrigo de Sierra, secretario ${ }^{55}$, Pero todos ellos se esforzaron en proseguir el plan trazado, y el cronista Argumosa pudo escribir en tono entusiasta:

«Este nuevo plan, que ciertamente formará época en la historia literaria de este Colegio, ha desterrado de nuestra aula el antiguo méthodo scolástico y el gusto al peripato, que por tan largo tiempo ha tiranizado nuestros estudios, en medio de la docta Italia, con razón llamada madre de las ciencias, en donde se cultivan con el mayor gusto todo género de amena y útil literatura. En virtud del nuevo méthodo de estudios, brillan en las di-

\footnotetext{
51 «Los disgustos nacieron de falta de economía en la conducta, defecto harto común en la juventud», dice el cronista y colegial Argumosa en 1785.

52 ACEB, Liber decretorum (1751-1830), ff. 453r-457r.

53 ACEB, De rebus gestis, II, ff. 231v-232r.

54 Ibidem, ff. 240v-243v.

55 Ibidem, f. 232r.
} 
sertaciones de nuestros colegiales la majestad, grandeza, armonía y abundancia de la lengua castellana, y se habla el latín puro y castizo, en lugar del improprio, bárbaro e inculto que por el pasado se oía en nuestras disertaciones y disputas. El argumento de nuestros discursos, siendo el elogio de los barones ilustres que ha producido la española, y particularmente de los que se han formado en este Real Colegio, y las quiestiones (sic) más provechosas de legislación universal, no puede menos de estimularnos a la imitación de los hechos y obras con que nuestros antecesores han inmortalizado el nombre de esta fundación» ${ }^{56}$.

Sólo se nos ha conservado el texto de doce disertaciones ${ }^{57}$ de las muchísimas que se pronunciaron en el Colegio de Bolonia desde enero de 1786 hasta fines del siglo XVIII. Pero, en cambio, se registraron en un libro especial ${ }^{58}$ los títulos de los trabajos y los nombres de los disertantes y de sus arguyentes, cuando los había. En dicho registro se anotaban estos actos y de algunos de ellos se conservan incluso los textos originales. Es la guía más segura para conocer las corrientes de pensamiento y de cultura que, procedentes de España o de Italia, confluían en el Colegio de San Clemente de los Españoles. En los dos años que van desde la implantación de este nuevo sistema de estudios, 6 de enero de 1786, hasta que el 26 de febrero de 1788 Alfranca obtuvo un puesto en la Audiencia de Sevilla y don Simón Rodríguez Laso, maestrescuela de Ciudad Rodrigo, fue nombrado rector en propiedad por Carlos III, se trataron gran variedad de temas, así en los actos privados -alguien más que los escasos colegiales asistirían a ellos- como en los públicos o solemnes, que solían tenerse en latín o en italiano.

De este modo, se nos brinda la oportunidad de asistir a un debate que parece reproducir, aunque en escala reducida, el gran debate que la Ilustración europea había abierto por todas partes. Junto a los temas más tradicionales de derecho canónico y de historia eclesiástica, aparecen temas de derecho civil moderno y de economía. Sólo se nos ha conservado el texto de doce disertaciones ${ }^{59}$ de las muchísimas que se pronunciaron en el Colegio de Bolonia desde enero de 1786 hasta fines del siglo XVIII. Con notable apertura, se establecía que las intervenciones pudieran ser no sólo en latín, sino en español e incluso en francés y hasta en inglés. Gracias a Alfranca penetraron en el Colegio de Bolonia los temas jurídicoeconómicos de actualidad y se establecieron en el Colegio una serie de actos públicos para estimular el empeño intelectual de los colegiales y dar fe ante los doctos boloñeses: ventajas e inconvenientes de los mayorazgos en España, el verdadero espíritu de la legislación para fomentar con fruto la agricultura, la industria, el comercio y las artes, la manera de reformar las leyes agrarias, etc.

\footnotetext{
56 Ibidem, ff. 259v-260r. BATLLORI, 1971, p. 662.

${ }^{57}$ ACEB, leg. Epsilon/10.

58 ACEB, M/IV, Libro de asiento de los exercicios del Colegio, que estará a cargo del colegial bibliotecario que por tiempo fuere (1786-1825).

${ }^{59}$ ACEB, leg. Epsilon/10.
} 
La renovación del método teológico aparece en discursos varios sobre la necesidad de la historia para el mejor estudio de la teología, sobre el influjo de las escuelas filosóficas así en las materias políticas como en las teológicas; se acepta la inutilidad y el perjuicio de la teología escolástica litigiosa, etc.

El regalismo, claro en los informes del Interrogatorio de Alfranca en 1791, sigue imperando en el orden canónico: se esfuman las fronteras entre la jurisdicción eclesiástica y la civil, se amplían los derechos del príncipe en la convocación y suspensión de los concilios y en la abolición de la exención de los regulares cuando convenga al bien común, se defienden los recursos de fuerza o sea la apelación a un tribunal civil en los procesos canónicos, y, con influencias claramente febronianas, se llega a atribuir a la autoridad civil el derecho de establecer impedimentos dirimentes al matrimonio, que lleguen a invalidar el mismo sacramento.

En cambio, el jansenismo netamente teológico no tiene en el Colegio partidarios: se refuta la distinción de hecho y de derecho, tan cara a los jansenistas franceses, y se impugna los excesos antirromanos del conciliábulo de Pistoya y su doctrina sobre la libertad y la gracia.

Los argumentos específicamente culturales mantienen a los colegiales de San Clemente en contacto con la realidad actual. Hasta 1796 (invasión napoleónica de Italia) la vida del Colegio fue casi la misma que había implantado el rector Alfranca.

Resumiendo, a partir de 1786, el rector Alfranca imprimió vigor al debate cultural que sugería el ambiente boloñés y la renovación que imponía la España de Carlos III, junto a la determinación de romper un peligroso aislamiento. Después del rectorado de Alfranca, no era ya justa la acusación, como había aseverado el ex jesuita Juan Andrés, de que los colegiales españoles sólo estudiaban leyes y cánones, que podían cursar igualmente en España, y que vivían de espaldas a las ciencias y aun a la filosofía ${ }^{60}$. El rector aragonés parece coincidir con el ex jesuita valenciano en que los colegiales se aplicasen a disciplinas más modernas en beneficio de la nación: «pues en pocos años podría llenarse la nación de sujetos instruidos, no sólo en leyes y cánones, que se pueden estudiar igualmente en España, sino en todas las ciencias naturales, en antiquaria, en lenguas y en toda suerte de filología y erudición» ${ }^{61}$. El rector Simón Rodríguez Laso (1788-1821) se encontró con un Colegio de San Clemente bastante integrado en la sociedad boloñesa, gracias a la labor del anterior rector, el aragonés don Juan José de Alfranca y Castellote.

60 BATLlori, 1971, p. 652.

${ }^{61}$ FroLdi, 1981, p. 149. 
Juan José Alfranca y Castellote, socio de la Real Sociedad EConómica Aragonesa de Amigos del País

Dejando aparte sus iniciativas reformistas en el seno del Colegio de San Clemente, sabemos que Alfranca era socio de la Económica Aragonesa (fundada en 1776 cuando ya estaba en Bolonia) y, dentro de las limitaciones originadas por la lejanía, procuró colaborar con la misma desde Italia. A pesar de pertenecer durante muchos años a la Sociedad Aragonesa de Amigos del País, Juan José Alfranca no tuvo una relación intensa con ella coincidiendo con el rectorado de Bolonia. Es nombrado socio en la junta general ordinaria del 21 de noviembre de 1783: «A proposición de don Ramón Ger, se nombró socio al Sr. D. Juan José Alfranca, rector del Colegio de San Clemente de Bolonia»62.

Alfranca ingresa en la Aragonesa en una época de crisis, por el progresivo abandono del sector aristocrático de la misma. Al mismo tiempo se amplían las actividades y se introducen nuevas enseñanzas con la Escuela de Economía Civil y Comercio, gracias a la inteligencia del magistrado Arias Mon, futuro regente y fundador de la Real Audiencia de Extremadura.

Todas las intervenciones de Alfranca en la Aragonesa estuvieron en relación con la escuela de dibujo y la publicación, como posible libro de texto, de uno del ex-jesuita expulso aragonés Vicente Requeno: Saggi sul ristabilimento dell'antica arte de' greci, e de' romani pittori (1784). Por el acta de la junta general ordinaria del día 5 de agosto de 1785 nos enteramos que Alfranca había enviado un escrito desde Bolonia, remitiendo dos cuadritos y dos ejemplares de la obra del abate Requeno sobre el restablecimiento de la pintura de los antiguos griegos y romanos:

«Viose una carta del señor socio don Juan José Alfranca, colegial de Bolonia, a la que acompaña dos cuadritos pintados por el método [encausto] del Sr. abate D. Vicente Requeno y dos ejemplares de la obra que ha publicado últimamente este célebre aragonés sobre el restablecimiento de la pintura de los antiguos griegos y romanos.

En su vista, acordó la Sociedad se le den cumplidas gracias al Señor Alfranca y que los dos cuadritos y ejemplares impresos de la obra del Señor Requeno se remitan al Sr. Goicoechea [amigo de Goya] para que, sirviéndose comunicarlos a los directores y profesores de la Escuela de Dibujo y demás inteligentes que le parezca, vean, puesto en ejecución, el referido método, excitándolos a la aplicación y adelantamientos que puedan hacerse, y que, oyendo el dictamen de dichos profesores, se sirva manifestarlo con el suyo a la Sociedad, extendiéndose a decirla si el señor Requeno merece que este Cuerpo le haga alguna distinción por su trabajo y mérito, y también si convendrá traducir a nuestro idioma la expresada obra, informándose antes de si se traduce ya en Madrid»63.

\footnotetext{
62 Archivo de la Real Sociedad Económica Aragonesa (ARSEA), Libros de Actas, tomo IX, año 1783 , f. 184r.

63 ARSEA, Libros de Actas, tomo XI, año 1785, ff. 159-160.
} 
Felix Latassa se hace eco de estas relaciones de Alfranca con la Económica Aragonesa, narrando el envío de un libro sobre la pintura al encausto del ex-jesuita Vicente para uso de la Escuela de Dibujo de la Real Sociedad64:

«Por mano del doctor don Juan de Alfranca, colegial y rector que fue del Mayor de San Clemente de Bolonia, ministro del Crimen de la Real Audiencia de Sevilla y oidor de la Real Audiencia de Cáceres o de Extremadura, vinieron de regalo a la Real Sociedad Económica Aragonesa estos trabajos en dos ejemplares con dos tablas pintadas en cera o al encausto, bajo la dirección del mismo abate ${ }^{65}$. La obra consta de 215 páginas y ocho en que da la instrucción práctica para la preparación de tablas o lienzos destinados a esta pintura. Se presentó todo a la referida Sociedad en su junta celebrada el viernes 6 de Agosto de 1785, y así los dichos cuadros como el escrito se remitieron a informe con el deseo de hacer socio de mérito al mencionado escritor» ${ }^{66}$.

El envío de Requeno era muy oportuno, pues desde hacía más de un año la Económica Aragonesa buscaba afanosamente materiales didácticos para su nueva Escuela de Dibujo: principios y modelos de diseño, yesos, grabados, etc. Había acudido a la Real Academia de San Fernando, al barón de La Linde, intendente de Cataluña, y a José Nicolás de Azara, quien, a mediados de agosto de 1784 envió desde Roma, vía Barcelona, ocho modelos de dibujo (una serie de cabezas de Rafael, dibujadas por Mens). Las perspectivas de crecimiento eran positivas, pues si en el primer curso de la Escuela, 1785-1786, asistieron 126 alumnos, en el curso siguiente, 1785-1786, concurrían $150^{67}$. Requeno estaba al corriente de las necesidades artísticas de la Aragonesa a través del rector Alfranca.

En la junta general del 12 de agosto de 1785 , viernes, se le pasa lo enviado por Requeno al rico burgués, Juan Martín de Goicoechea, sin duda el socio más experto en Arte y el más interesado en extender el Neoclasicismo artístico en

64 Sobre las relaciones de este ex-jesuita con la Aragonesa ver Antonio Astorgano ABAJO, «El abate Vicente Requeno y Vives (1743-1811) en la Real Sociedad Económica Aragonesa (1798-1801)», Rolde. Revista de Cultura Aragonesa, 85-86 (julio-diciembre 1998), pp. 56-73. A. AstorgANO, «Estudio introductorio», en Vicente REQUENO, Escritos filosóficos, Zaragoza, Prensas Universitarias, 2008, pp. LXIII-LXXVII.

${ }^{65}$ Requeno envía las dos tablas, hechas en Italia bajo su dirección, como demostración práctica de la técnica al encausto. Una de las tablas, pintada por Luigi Gibelli en Bolonia en 1785, contenía una perspectiva; la otra, obra de Giuseppe Artiolo, tenía pintadas dos perdices, y había sido realizada en Mantua en 1784. Aparecen catalogadas por N. LALANA y T. LloveT, «Catálogo de las pinturas y esculturas que posee y se hallan colocadas en las Salas de la Real Academia de San Luis de la ciudad de Zaragoza, dispuesto... en 29 de abril del año 1828», Boletín del Museo Provincial de Bellas Artes de Zaragoza, 12, (1926), pp. 38-53.

${ }^{66}$ Felix LATASSA, Biblioteca de escritores aragoneses, Pamplona, 1802, t. VI, 1802, p. 271.

${ }^{67}$ Arturo Ansón Navarro, Academicismo y enseñanza de las bellas artes en Zaragoza durante el siglo XVIII: precedentes, fundación y organización de la Real Academia de Bellas Artes de San Luis, Zaragoza, Real Academia de Nobles y Bellas Artes de San Luis, 1993, pp. 102-103.

Hispania Sacra, LXI

123, enero-junio 2009, 279-352, ISSN: 0018-215-X 
Zaragoza, a cuyo fin no dudaba en sufragar generosamente la Escuela de Dibujo de la Aragonesa:

«Dijo el secretario que en el propio día 9 pasó al señor Goicoechea el correspondiente oficio acompañado de la carta original del señor Alfranca con los dos cuadritos y un ejemplar impreso de la obra del señor abate Requeno» ${ }^{68}$.

En la junta del 19 de agosto, viernes, Goicoechea, como no podía ser menos en un fervoroso neoclásico, da su informe totalmente favorable a la obra de Requeno sobre el encausto y solicita su traducción:

«El señor Goicoechea, en contestación del 18 del corriente, hizo el correspondiente elogio de la obra escrita por don Vicente Requeno y de los experimentos y ensayos que se le remitieron. Y podría la Sociedad manifestar a este célebre escritor su reconocimiento y empeñarle a que, continuando sus servicios a la Patria, tomase a su cargo la traducción de la obra para la ilustración de los pintores españoles y que pudiesen seguir el ejemplo de los de Italia. En cuya vista, la Sociedad acordó que por mano del señor Alfranca, que es el conducto por donde se recibió la obra y ensayos [los cuadritos], se empeñe al autor a que haga la traducción, encargándole al señor Alfranca le manifieste el más ingenuo reconocimiento y gratitud de parte de la Sociedad» 69 .

En la junta del 30 de septiembre de 1785, viernes, se colocan los cuadros en un lugar relevante y, como muestra del interés que habían suscitado entre los socios, el catedrático de prima de cánones de la Universidad de Zaragoza, don Judas Tadeo Lasarte, estaba estudiando el libro y las pinturas que lo ilustraban:

«Últimamente pidió el señor censor se colocasen en la sala de la Sociedad los cuadritos remitidos por el señor Requeno, a que expuso el secretario tenía uno de ellos el señor Lasarte, con un ejemplar de la obra. Y pidiendo este señor se le dejase en su poder por algunos días, respecto de que lo necesitaba para sus observaciones, le fue concedido» ${ }^{70}$.

Los dos «cuadritos» eran tablas pintadas al encausto, bajo la dirección de Requeno, como demostración práctica de dicha técnica. Una, obra de Luigi Gibelli en Bolonia en el año 1785, representaba una perspectiva. La otra, realizada en Mantua en 1784 por Giuseppe Artioli, tenía pintadas dos perdices ${ }^{71}$.

A principios de 1786, por medio del rector Alfranca, Requeno se compromete a traducir su obra, advirtiendo claramente que la impresión correrá a cargo de la Aragonesa, pues aunque ya empezaba a cobrar pensión doble, su economía personal estaba muy lejos de permitirse tal gasto. Según el acta del día 31

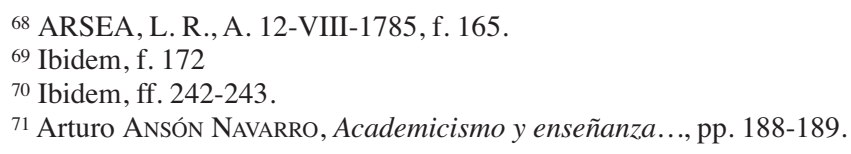


de marzo de 1786, el rector Alfranca envía un oficio, fechado en Bolonia el 3 de marzo de 1786, en el que le comunicaba a la Aragonesa que el Sr. Requeno se ofrece a traducir su obra:

«El señor don Juan José Alfranca, mediante oficio, fechado en Bolonia a 3 de marzo ofrece que el señor Requeno tomará a su cargo la traducción de la obra escrita por él mismo en italiano sobre el método del pintar de los antiguos griegos y romanos, bajo el concepto de que la imprimirá a sus expensas la Sociedad. Quedó entendida de ello y encargó al secretario escribiese las gracias» 72 .

En otro lugar hemos narrado los avatares de esta fallida traducción, por sus numerosos italianismos, a pesar de que, entre 1789 y 1798, pasó por manos de varios y destacados socios de la Económica Aragonesa, incluido el poeta Juan Meléndez Valdés. Retornado a España, Alfranca asistió sólo a dos juntas generales de la Aragonesa, a lo largo del otoño de 1788, las del 24 de octubre de 1788 y del 21 de noviembre. Fue en los pocos meses que van desde que dejó el rectorado del Colegio de Bolonia y su incorporación al nuevo destino en la alcaldía del crimen en la Real Audiencia en de Sevilla. Sólo intervino activamente en la del 24 de octubre y en relación con el libro y la técnica de pintura del ex jesuita Vicente Requeno:

«El señor Alfranca hizo presente las atenciones y el respeto que el señor Requeno le había encargado para este Real Cuerpo, y que tenía concluida la traducción de su obra sobre el encausto, mediante el encargo particular que le hizo la Sociedad, cuya traducción estaba esperando para presentarla a la misma [Sociedad], de que le dieron las debidas gracias al Señor Alfranca, así por el cuidado que tomó en este negocio, como por todo lo demás que ha trabajado en beneficio del Cuerpo, asegurándole que, luego que viniese esta obra, haría la Sociedad de ella el aprecio que se merece» ${ }^{73}$.

La otra asistencia de Alfranca fue a la junta general ordinaria de la Aragonesa del 21 de noviembre de 1788, quizá porque en ella se trató mucho sobre la escuela de dibujo que la Aragonesa pretendía convertir en una academia de bellas artes, pero no intervino ${ }^{74}$.

En resumen, salvo en el caso concreto del libro de Requeno no nos consta la contribución de Alfranca a las tareas reformistas de la Aragonesa. Sin embargo, la Sociedad se muestra agradecida y da la impresión que desde Bolonia hizo otras gestiones, pues se menciona «todo lo demás que ha trabajado en beneficio del Cuerpo». Tampoco nos consta que en el periodo 1799-1810, en el que el desterrado Alfranca debió residir grandes temporadas en Zaragoza, volviese a

\footnotetext{
72 ARSEA, Libros de Actas, tomo XII, año 1786, ff. 68v-69r

73 ARSEA, Libros de Actas, tomo XIV, año 1788, f. 224v.

74 Ibidem, ff. 234r-238v.
} 
asistir a las juntas generales (semanales) o particulares de las distintas escuelas de la Real Sociedad Aragonesa.

Juan Josef Alfranca, magistrado de lo penal de la Audiencia de Sevilla (1789-1790)

Por el momento son pocos los datos específicos que conocemos de los dos años en que Alfranca ejerció como «ministro de la cuadra» o alcalde del crimen de la Audiencia de Sevilla (1788-1790) y de los nueve del Alfranca oidor de la Audiencia de Extremadura (1790-1799), debido a su funcionamiento colegiado.

Como era habitual, Juan José pone su cargo a disposición de las autoridades sevillanas, dando cuenta de su nombramiento como alcalde del crimen. Así, en el Cabildo del miércoles 5 de noviembre de 1788, presidido por el Sr. Arcediano de Sevilla, se leyó una carta de don Juan José Alfranca, fechada en Zaragoza el 13 de octubre de 1788 en un magnífico papel azulado, «en que da cuenta haberlo su majestad nombrado alcalde del crimen de esta Real Audiencia. Se cometió su respuesta al señor maestrescuela» ${ }^{75}$. En ella informa de los antecedentes:

«Aunque desde el año pasado [1787] merecí a la piedad del Rey una plaza de ministro de la Cuadra de la Real Audiencia de esa ciudad, no cumplí inmediatamente con la atención que me merece ese Ilmo. Cuerpo, por hallarme de residencia en Italia. Cumplo ahora con este acto de mi respeto, apenas llegado de España, ofreciéndole mi persona y facultades para cuanto sea de su agrado» ${ }^{76}$.

El 3 de febrero de 1789 Juan José Alfranca solicita en Madrid al Consejo de Castilla una prórroga en su incorporación y toma de posesión de la alcaldía del crimen de Sevilla. Manifiesta que «el día 10 del corriente mes de febrero [1789] se cumplirá el término que le ha prefijado vuestra majestad para tomar posesión de la plaza del ministro del crimen de la Real Audiencia de Sevilla, por su Decreto de 10 del pasado [enero 1789] y no habiendo podido ponerse en camino hasta ahora ni hallado disposición cómoda para ello, por lo rígido de la estación y por las copiosas lluvias que se han experimentado, y previendo que, sin embargo de tener ya dispuesta su salida de esta Corte para el día 5 del corriente [febrero de 1789], no podrá llegar a Sevilla dentro del plazo que se le ha señalado, aún cuando no le suceda alguno de los contratiempos y retardos que son ordinarios en los viajes largos» ${ }^{77}$. Se le prorroga el plazo veinte días más.

75 Archivo Capitular de Sevilla (ACS), Libro 151. Libro de autos capitulares del año 1788, f. 93r.

76 ACS, Libro 404 (14). Cartas originales de personas eclesiásticas y seculares al cabildo, años 1780-1797, sin foliar.

77 AHN, Consejos, Memoriales, leg. 9812-II. 
Para desgracia suya, Juan José tuvo como colega suyo en Sevilla a José Antonio Caballero, quien perseguirá cruelmente al mismo Alfranca, a Meléndez Valdés, a Jovellanos y a otros magistrados, después de 1798, cuando sea ministro de Gracia y Justicia. En efecto, José Antonio Caballero se presenta, como «alcalde de La cuadra de esa Real Audiencia», al cabildo de Sevilla el 31 de julio de 1787 en protocolaria carta fechada en Salamanca ${ }^{78}$.

\section{Alfranca, oidor en la Real Audiencia de Extremadura (1791-1799)}

Su nombramiento «para la segunda plaza de oidor de la nueva Audiencia, creada para la provincia de Extremadura con situación en la villa de Cáceres», lleva como fecha el 23 de septiembre de 1790, según acordado de la Cámara de Castilla del día anterior ${ }^{79}$. La aceptación de Alfranca está fechada en Sevilla, el 16 de octubre de 1790, y va dirigida al «Excmo. Sr. Conde de Campomanes»:

«En carta de 6 de corriente me avisa vuestra excelencia que su majestad se ha servido nombrarme para la segunda plaza de oidor de la nueva Audiencia de Extremadura con residencia en Cáceres. Quedo enterado de la gracia que he merecido a la piedad del Rey y dispuesto a servir a su majestad en dicha plaza y en cualquiera destino que fuere de su agrado.

Acudiré a la secretaría de la Cámara, como vuestra excelencia me previene, a sacar los despachos correspondientes; y, en cuanto al día en que deberé estar en Cáceres para el servicio de la plaza, me arreglaré al contenido de dichos despachos o a las órdenes que vuestra excelencia se sirva hacerme comunicar sobre el particular» ${ }^{80}$.

Se da la coincidencia de que Juan Meléndez Valdés también estuvo propuesto, el citado día 23 de septiembre, por la Cámara de Castilla, entiéndase, por el gobernador Campomanes, seguido por los consejeros, conde de la Cañada, marqués de Roda, don Santiago de Espinosa, don Juan Mariño y don Antonio Cano Manuel, para la segunda plaza que obtuvo Alfranca, pues figura entre los «consultados» para la misma:

«En conformidad de lo que hace presente a vuestra majestad la Cámara en consulta separada de este día, proponiendo para la plaza de regente de la nueva Audiencia que vuestra majestad se ha servido crear en Extremadura, propone igualmente en esta [consulta] para la segunda plaza de oidor o ministro de los cuatro civiles que ha de haber en ella, según Real Pragmática Sanción de 30 de marzo de este año [1790] que trata del establecimiento de dicho tribunal, los sujetos que le parecen más a propósito, según sus méritos que constan de las adjuntas relaciones:

78 ACS, Libro 404 (14). Cartas originales de personas eclesiásticas y seculares al cabildo, años 1780-1797, sin foliar.

$79 \mathrm{AHN}$, Consejos, leg. 13488.

80 Idem.

Hispania Sacra, LXI

123, enero-junio 2009, 279-352, ISSN: 0018-215-X 
En primer lugar, a don Juan José Alfranca y Castellote.

En segundo, a don García Gómez Jara, don Juan Mariño y don Antonio Caro, a don Juan Meléndez Valdés, el marqués de Roda y a don Ramón Cid de Araujo.

En tercer lugar, a don Isidoro Lasauca, don Santiago de Espinosa y Don Juan Mariño, a don Antonio Cano Manuel y Ramírez, don Antonio Cano, a don Pedro José de Torres y Rus.

Vuestra majestad nombrará al que fuese más de su real agrado.

Madrid, 23 de septiembre de $1790 »^{81}$.

\section{La Real Cédula de nombramiento de oidor de Juan José Alfranca especifica:}

«Confiando en la suficiencia, fidelidad y demás letras de vos, don Juan José Alfranca y Castellote, alcalde de la cuadra de mi Audiencia de Sevilla, y entendiendo que así conviene a mi servicio y a la mejor administración de la justicia, he tenido a bien el elegiros y nombraros, como por la presente os elijo y nombro, para la segunda de las cuatro plazas de ministro de lo civil que ha de haber en la mencionada mi Audiencia de Extremadura, en que habéis de preferir en antigüedad a don Francisco Javier de Contreras y a don Juan Antonio Inguanzo, a quienes, al mismo tiempo, he nombrado para la tercera y cuarta plaza» ${ }^{82}$.

El oidor Juan José Alfranca se presenta por carta al Ayuntamiento de Cáceres del 3 de noviembre de 1790, en el que se leyó:

«Otra carta del Sr. D. Juan José de Alfranca y Castellote, su fecha en Sevilla, a 23 de octubre de este mismo año, en la que participa a esta Villa la gracia que ha merecido a la piedad del Rey, nombrándole para la segunda plaza de oidor de la dicha Real Audiencia que se establece en esta villa, ofreciéndola complacerla en cuanto lo contemple útil este respetable cuerpo» ${ }^{83}$.

El ascenso de Alfranca se vio favorecido por excluirse del tribunal a los naturales de las provincias de Cuenca, Soria, Segovia y Rioja, para evitar suspicacias relacionadas con los intereses ganaderos de la Mesta. Poco se sabe de la actividad concreta del oidor Alfranca en Cáceres, pues es sabido que las Audiencias funcionan colegiadamente en Salas y sus sentencias no eran motivadas, por lo que cuando aparecen los distintos nombres de cada oidor es para el despacho de los trámites reglamentarios, sin mayor interés ideológico o profesional.

Sin embargo, su carácter íntegro y no moldeable, como buen aragonés, y cierta cabezonería, siempre justificada, parece haber ocasionado algún enfrentamiento de Alfranca con la Sala de Alcaldes del Crimen; por ejemplo, sobre el lugar más adecuado para colocar la guardia de la cárcel ${ }^{84}$. Por este expediente

81 Idem.

82 Archivo Histórico Provincial de Cáceres (AHPC), Audiencia, Legajo 229, Exp. 1, ff. 3-3v.

${ }^{83}$ Archivo Histórico del Ayuntamiento de Cáceres, Libro de Acuerdos (1790-1797), sin foliar.

84 «Expediente formado en razón de que no se ponga tropa de guardia en la cárcel de Corte, sin permiso de la Sala, de orden del Sr. D. Juan José de Alfranca. Escribano del gobierno, don Sebastián de Arjona y Sánchez». AHPC, Audiencia, caja 227, expediente 47. 
da la impresión de que Juan José de Alfranca, en el verano de 1793, se enfrentó con los alcaldes del crimen y con el mismo regente Arias Mon ${ }^{85}$. No vamos a relatar el incidente, pero lo cierto es que, por orden de «los señores regente y alcaldes del crimen de la Audiencia de su majestad [es decir, el regente Arias Mon, don Melchor Basadre, don José Palacio y don Pedro Sanchoyerto] en la madrugada del día 26 del corriente mes [julio de 1793], se retiró la tropa de caballería del regimiento de Alcántara que, de orden del Sr. D. Juan José de Alfranca, estaba de guardia en dicha cárcel para la custodia y seguridad de los reos presos en ella por la comisión en que se halla entendiendo» ${ }^{86}$.

En mayo del año siguiente Alfranca tuvo problemas con las autoridades de Castuera, patria de Godoy, tan graves que tuvo que intervenir Eugenio de Llaguno, ministro de Gracia y Justicia, para espaldar la autoridad de Alfranca, con la siguiente Orden, fechada en Aranjuez el 3 de mayo de 1794 y dirigida al regente Arias Mon:

«En vista de una representación de D. Juan José de Alfranca, oidor de esa Real Audiencia, acerca de la queja que dieron, contra él, don Simón Fernández Daza, alcalde de la Villa de Castuera, el año anterior, el escribano Juan Antonio Martínez Matamoros y Juan Caballero Tena, de resultas de haber cortado dicho ministro, en virtud de la real comisión de leva que se le encargó, varias causas pendientes en el juzgado de dicha villa de Castuera entre Juan Caballero y Miguel Sánchez Ciudad, y su yerno don José de Tena Moya, la mujer y madre de dicho Juan Caballero, sobre injurias verbales y reales, habiendo condenado entre otros a [Fernández] Daza a poner a su costa dos reclutas para el ejército, y a Matamoros y Caballero un recluta cada uno, con varios apercibimientos por las causas que resultaron en los autos contra ellos y expresa Juan José Alfranca, enterado el rey de todo, y satisfecho de la conducta y procedimientos de dicho ministro [Alfranca], ha venido en resolver que se lleven a efecto sus providencias sobre este asunto en todas sus partes, moderándolas solamente en que el don Simón Fernández Daza ponga un hombre solo en lugar de los dos en que le condenó, como así se lo prevengo de Real Orden con esta misma fecha para su cumplimiento en la parte que le toca. Que vuestra señoría [Arias Mon] haga comparecer a Fernández Daza y se le dé una severa represión por las expresiones libres e indecorosas con que ha tratado en su recurso a un ministro de su majestad [Alfranca], y que esa Audiencia esté a la mira para procurar se extingan los bandos y enemistades en Castuera, corrigiendo a los que de cualquier modo las fomenten. Todo lo cual prevengo a vuestra señoría [el regente Arias Mon] de orden de su majestad para su inteligencia y cumplimiento en la parte que le toca» ${ }^{87}$.

Su rectitud de carácter debió estar en el origen de su fulminante destierro, el cual, a su vez, debe estar ligado al misterio que rodea el periodo de 1799-1810 en la vida de Alfranca. En efecto, fue apartado, sin contemplaciones, de su ofi-

\footnotetext{
85 AHPC, Audiencia, caja 227, expediente 47.

86 Idem.

${ }^{87}$ AHPC, Audiencia, caja 228, expediente 22.
}

Hispania Sacra, LXI

123, enero-junio 2009, 279-352, ISSN: 0018-215-X 
cio de magistrado por una orden comunicada el 5 de febrero de 1799 por el ministro reaccionario José Antonio Caballero, autor, como es sabido, de las desgracias de Meléndez, Jovellanos y de la condesa de Montijo, entre otros eminentes ilustrados:

«Con esta fecha comunico al regente de la Audiencia de Extremadura lo siguiente:

El Rey se ha enterado de los notorios excesos de don Juan José de Alfranca y Castellote, oidor de esa Audiencia, y le ha sido del mayor desagrado una conducta tal opuesta a el bien de sus amados vasallos, por el que estaba velando incesantemente. Y no pudiendo su paternal amor mirar con indiferencia unas vejaciones de esta clase, y por la misma mano que había autorizado y honrado para aliviarlas, en decreto de ayer [4 de febrero de 1799] se ha servido separar a dicho Alfranca de su plaza, desterrándole perpetuamente de esa ciudad, Madrid y Sitios Reales, y dejándole, sólo por conmiseración, 4000 reales anuales.

Lo que participo a vuestra señoría, de orden de su majestad, para que se lo haga saber y lo haga presente después, reservadamente, en Acuerdo pleno de esa Audiencia».

Y de la misma Real Orden lo participo a vuestra excelencia para que conste en la Cámara para los efectos que haya lugar.

Dios guarde a vuestra excelencia muchos años.

Aranjuez, 5 de febrero de 1799.

José Antonio Caballero.

Señor gobernador del Consejo de Castilla» 88 .

Para cubrir la plaza del desterrado Alfranca fue nombrado Benito Arias de Prada, alcalde del crimen más antiguo. Parece que la destitución fue aprovechada por el ministro reaccionario de Gracia y Justicia, José Antonio Caballero, y por los sectores menos progresistas de Cáceres, para reorganizar jurídica y administrativamente la ciudad, pues desde hacía cuatro años un oidor asumía las funciones de corregidor.

Retrocedamos al momento de la creación de la Audiencia y a los afanes de su regente, Arias Mon, por fortalecerla. Utilizó la circunstancia de que el corregidor de Cáceres había solicitado aumento de sueldo (5876 reales) en 1790 , para conseguir que la Audiencia asumiese las funciones de corregidor y alcalde mayor de Cáceres, según orden de la Cámara de Castilla, en sesión del 19 de abril de 1795 .

Cuando sucedieron los «excesos» que motivaron el destierro de Alfranca en febrero de 1799, el sector de la opinión pública de Cáceres que deseaba el restablecimiento independiente del cargo de corregidor se lucra de la destitución de Alfranca para pedir la supresión de la quinta plaza de oidor y volver a la organización administrativa anterior, de separación entre Ayuntamiento y Audiencia ${ }^{89}$.

88 AHN, Consejos, leg. 13488.

${ }^{89}$ AHN, Consejos, leg. 13488. 
Parece evidente que, además de los «excesos» de Alfranca, hubo una clara motivación política y que el utrareaccionario ministro de Gracia y Justicia, José Antonio Caballero, aprovechó la situación para suprimir la quinta plaza de oidor y con los dineros sobrantes restablecer el rancio sistema jurídico-administrativo de la ciudad: un gobernador de la Sala del Crimen que coordinase los asuntos penales y un corregidor independiente que gestionara la vida ciudadana.

También es probable que los problemas para el oidor Alfranca surgiesen con motivo de la elaboración de las ordenanzas que se estaban preparando, a lo largo de 1798, para el gobierno del tribunal de Cáceres ${ }^{90}$. Parece claro que el regente Arias Mon no hizo nada por amortiguar la persecución de Alfranca, aun siendo viejos conocidos de los tiempos de la Económica Aragonesa, a juzgar por el muy distinto signo de sus trayectorias profesionales posteriores. Alfranca caía en el más completo ostracismo, mientras Arias Mon era ascendido a presidente de la prestigiosa Chancillería de Valladolid. El 23 de junio de 1799, el regente Arias Antonio Mon abandona su cargo, según el «auto del Sr. decano de esta Audiencia para acreditar el día de la salida de Sr. Regente de ella»91. A finales de marzo de 1799 ya se le había nombrado sustituto al defenestrado oidor Alfranca:

«Y últimamente, habiendo tenido por conveniente separar de su plaza de ministro de la citada mi Audiencia de Extremadura a don Juan José de Alfranca y Castellote, por decreto señalado de mi real mano de 4 del propio mes de febrero de 1799, nombré para ella, a vos don Benito Arias de Prada, alcalde del crimen más antiguo de dicho tribunal» ${ }^{92}$.

\section{AlFRANCA, VISITADOR DEL PARTIDO DE LLERENEA}

Los rasgos del jurista reformador Alfranca, ya apuntados en el rectorado de Bolonia, se confirman plenamente con motivo de dirigir el Interrogatorio del Partido de Llerena en 1791, demostrándonos que, sin duda, fue el mejor preparado intelectual y jurídicamente de los diez magistrados fundadores de la Real Audiencia de Extremadura. Mejor incluso que el regente, Arias Antonio Mon y Velarde, que llegará a ser presidente del Consejo de Castilla.

Fue tremendo el choque entre el idealismo ilustrado de los diez magistrados y del utópico Discurso de apertura de Meléndez Valdés ${ }^{93}$ y la triste realidad so-

90 AHPC, Audiencia, caja 235, expediente 43.

${ }^{91}$ AHPC, Audiencia, caja 194, expediente 3.

92 AHPC, Audiencia, caja 229, expediente 1, f. 60.

${ }^{9}$ Sobre las utopías y filantropismo de este magnífico discurso reformista, vid AsTORGANO ABAJO, «Las referencias aragonesas del Discurso de apertura de la Real Audiencia de Extremadura», Revista de Estudios Extremeños, Tomo LIII, número I, Enero-Abril, 1997, pp. 75-155. 
ciológica de Extremadura ${ }^{94}$. Pronto se dieron de bruces con las necesidades más elementales, que obligaron a la Audiencia, a través de diversas representaciones del regente Arias Mon, a ir dejando muchas de sus aspiraciones reformistas en el campo económico y educativo para centrarse en las específicamente judiciales, en especial en el mundo de la criminalidad ${ }^{95}$.

Da la impresión de que el magistrado que más sufrió ese choque fue el culto y refinado Alfranca, ex-rector y ex-catedrático de Bolonia. Hizo un concienzudo reconocimiento del Partido de Llerena, que era más que suficiente para familiarizarse con la realidad de toda Extremadura. Se encontró con una «Provincia» organizada irracionalmente desde todos los puntos de vista, en la que confluían muchas jurisdicciones y pesaban muchas cargas. Una larga frontera con Portugal favorecía el contrabando (sobre el que hizo un excelente estudioinforme para el ministro de Hacienda, conde de Llerena, antes de finalizar el Interrogatorio de su Partido). Todo esto sucedía en medio de continuas guerras fronterizas. Si Meléndez Valdés había advertido a los magistrados de la nueva Audiencia en el Discurso de apertura ${ }^{96}$ que se encontrarían con una región, «generalmente desconocida» y con «un país dividido entre infelices jornaleros y hacendados poderosos, que habían sofocado con su voz imperiosa el genio del pobre y hecho valer, para arruinarlo con mil injustas pretensiones, el dinero y el favor»; con un país en el que «delitos graves habrá habido escandalosamente autorizados o disimulados, mientras que otras faltas livianas se hayan acriminado con encono y furor; calumnias y maquinaciones disfrazadas con el velo de un celo santo, o de la común utilidad...», la realidad superaba las peores predicciones. Era situación peor que la que acababa de observar últimamente como alcalde del crimen en la Audiencia de Sevilla. Le sorprende el influjo de la poderosa Mesta y en su informe sobre la visita que realiza a la provincia recoge algunas prácticas y abusos a los que sometía a algunos pueblos del partido de Llerena, tales como la quema del monte provocada por los ganaderos.

En síntesis, la Real Audiencia se instala en una provincia necesitada de una intervención real que hiciera llegar a Extremadura el beneficio de las reformas borbónicas, una tierra «sin población, sin agricultura, sin caminos, industria ni comercio, todo pide, todo solicita, todo demanda la más sabia atención» ${ }^{97}$. El

\footnotetext{
94 No podemos extendernos aquí, por lo que remitimos al lector al estudio y a la edición de dicho Interrogatorio a cargo de Salvador Rodríguez Becerra (1994).

95 Vid. Astorgano, «La repoblación de Extremadura y su Real Audiencia a finales del siglo XVIII», en Actas de la IX reunión Científica de la Fundación Española de Historia Moderna, celebrada en Málaga entre el 7 y el 9 de junio de 2006 (en imprenta). También, AstorgAno, «Meléndez Valdés, y el Informe sobre el estado de la agricultura en Extremadura (1792) de Arias Mon», en la revista Trienio, 50 (Noviembre 2007), pp. 5-48.

96 Astorgano, 2004b, pp. 1120-1122; Astorgano, 2007, pp. 592-595.

97 Astorgano, 2004b, p. 1117.
} 
refinado oidor Alfranca emprende su trabajo en Extremadura con un entusiasmo que nos recuerda el de Meléndez en el citado Discurso de apertura, pronunciado el 27 de abril: «obremos y mejoremos y sean nuestras sabias consejeras la razón y la filosofía».

Salvador Rodríguez Becerra nos recuerda que el Alfranca oidor-visitador llevó a cabo la visita y entregó su informe al Real Acuerdo el 17 de diciembre de 1791. Capta perfectamente los rasgos, ya vistos, de la personalidad del exrector-catedrático Alfranca a través del amplio y documentado informe general del partido de Llerena, «en el que demuestra su formación jurídica, pues se refiere en varias ocasiones a leyes y decretos que eran de aplicación al caso que le ocupaba; parece, asimismo, tener buen conocimiento del derecho canónico en el que se mueve con soltura. Es también un funcionario ilustrado y regalista que se muestra celoso de las prerrogativas reales frente a otros tribunales y jurisdicciones» ${ }^{98}$.

Como ex catedrático de Cánones y residente en los Estados Pontificios, Alfranca estaba al corriente de la pugna de los Borbones contra el papa, de quien habían conseguido ciertas prerrogativas que sujetaban la Iglesia al poder real. Como ex-superior de los sobrinos de Campomanes y Floridablanca, sabía lo que pensaban las minorías ilustradas, que diferenciaban entre cuestiones de fe que atañen exclusivamente a la Iglesia y el carácter temporal de ésta, y sostenían que el tribunal de la Inquisición, con una sede en Llerena desde 1508, debía estar sometido a los intereses del Estado y actuar exclusivamente en materias de herejía y apostasías.

Hemos visto que, durante su rectorado, se disertaba en el Colegio de Bolonia de asuntos de economía a la luz de las nuevas teorías filosófico-económicas. Por eso, es acertada la observación de Rodríguez Becerra sobre la defensa de la propiedad, evidente en Alfranca, con la precaución de dar una acepción amplia al sintagma «tendencias liberales», que habría que confirmar con escritos posteriores del mismo oidor, y, sobre todo, con su conducta «independiente» durante la Guerra de la Independencia, cuando gobernará la diócesis de Teruel ${ }^{99}$. Nuestro oidor aparece como un gran conocedor de las técnicas agrícolas modernas y de los tratados publicados en Inglaterra, Francia e Italia. Quien supo bandearse perfectamente en la sociedad boloñesa, se

\footnotetext{
98 RodríGUEZ BECERRA, 1994, p. 14.

99 «Como hombre de la Ilustración y de tendencias liberales, tiene fe ilimitada en la propiedad privada, fórmula que considera muy superior a la propiedad compartida e incluso a los arrendamientos a corto plazo. Estos principios los refleja en la siguiente ecuación: hacer buenos agricultores y propietarios de tierras conduce a la felicidad y progreso de los ciudadanos y, consecuentemente, de la patria y el soberano que la representa tendrán todo su apoyo. Manifiesta asimismo cierto horror a la multiplicidad de legislaciones, jurisdicciones y situaciones y se muestra partidario de la unidad y la centralización racionalista del Estado» (RoDRÍGUEZ BECERRA, 1994, p. 14). 
nos presenta como un profundo reformista, pero suave en las formas y, hasta cierto punto, respetuoso con la tradición. Partidario de intervenir en las costumbres populares modificando las prácticas rituales y festivas, así como la costumbre de inhumación en las iglesias, preconiza la habilidad necesaria para evitar alteraciones. Hombre letrado y racionalista, busca el bien común a partir de la regeneración.

El visitador conoce la fuerza de las tradiciones y su dificultad para cambiarlas, y por ello recomienda que toda actuación «causase la menor impresión que fuese posible en el bajo pueblo, disponiéndolo de antemano con suavidad a recibir con gusto esta novedad y usando de los medios de suavidad necesarios para que semejantes novedades no alarmen a estos pueblos, cuya religión material los conduce a estas expresiones groseras de devoción». Aparece en esta propuesta, que eleva al Real Acuerdo para que actúe «corrigiendo» estos comportamientos, el hombre letrado y racionalista, que busca el bien común a partir de la regeneración, aunque admite la función que cumplen estas prácticas rituales y por ello insiste en que «no debe quitarse del todo a los pueblos el desahogo de su devoción en los simulacros expuestos a la pública veneración en las ermitas o santuarios, porque ocurren a ellos en sus necesidades...», y a continuación propone reducir y destruir aquellas ermitas más alejadas de las poblaciones y que no sirvan como ayudas de parroquia. La propuesta del oidor, exclusivamente racionalista y utilitaria, no debió tener en cuenta otras funciones de carácter simbólico, ecológico, reivindicativas e identificadoras de la comunidad, etc. que justifican la ubicación de las ermitas en un determinado lugar ${ }^{100}$.

En síntesis, Alfranca cumple con creces el encargo de inspeccionar los pueblos del partido de Llerena que se le encomendó y de informar sobre las cuestiones más necesitadas de la intervención regia a través de la Real Audiencia. Entiende que hay que desarrollar la agricultura y el «aumento de todos los ramos que puedan proporcionar a los pueblos de Extremadura su prosperidad», introduciendo innovaciones tecnológicas y removiendo las normas legales que lo impiden. Es una síntesis de la idea de progreso ilustrado que encarnó Jovellanos. Analiza críticamente la legislación sobre privilegios de la Mesta, usos indebidos de los montes y dehesas, derechos de los criadores de caballos, acceso a la propiedad o contratos de arrendamiento de larga duración, etc.

Propone la utilización social de las rentas y propiedades de obras piadosas, la disminución del clero sin destino remunerado, la eliminación o subordinación de las jurisdicciones civiles y eclesiásticas y la de las Órdenes a los tribunales y autoridades reales de la provincia y la generalización, en los pueblos que ello fuera posible, de la presencia de jueces profesionales, los alcaldes ma-

100 RodRÍGUEZ BECERRA, 1994, p. 15. 
yores, con la supresión de los procedimientos legales y consuetudinarios que otorgaban todo el poder local a ciertas oligarquías. Pide también la abolición de los privilegios señoriales para igualar a todos los vasallos y evitar, «a quienes ha tocado, no sé si digo, la infeliz suerte de nacer en pueblos de señorío», esta discriminación, porque la soberanía nacional no debe «corresponder por derecho de sucesión sino al soberano y a sus representantes en su nombre», es decir, a la Real Audiencia de Extremadura.

En este tema de la unificación legislativa, central en la concepción de Alfranca y Castellote, es radical: si no se someten todas las jurisdicciones a la Audiencia y a su Real Acuerdo, ésta habrá fracasado, su creación no tendría justificación y «la Provincia continuará en el abatimiento y en el estado infeliz en que la ha puesto su constitución y en que se halla al presente» ${ }^{101}$.

Alfranca durante la visita se encuentra con una sociedad que vive bajo leyes y normas culturales nacidas en los tiempos de la conformación de estos territorios tras las conquistas castellano-leonesas a los musulmanes, consolidadas y generalizadas en la Edad Moderna; como de «rezago de la feudalidad» calificará la situación el oidor al referirse a la jurisdicción que tenía la nobleza sobre sus señoríos. Unas circunstancias históricas muy singulares configuraron a Extremadura como una región con escasa demografía y poca significación económica y política, enseñoreada por las Órdenes militares de Santiago y Alcántara y posteriormente también por la nobleza, la presencia masiva de ganado trashumante y la carencia de grandes ciudades en el territorio.

El oidor ilustrado, que conoce otras formas socio-económicas de tenencia y uso de la tierra, y otras formas de organización socio-política, va a encontrar anacrónicas las comunidades de pastos en varios pueblos, el predominante adehesamiento que favorece a los ganados trashumantes en perjuicio de las ganaderías locales, la inexistencia de pleno dominio en las dehesas y baldíos, los repartos anuales de tierras entre jornaleros...

Juzga nocivas la concurrencia de varias jurisdicciones sobre un mismo territorio y la carencia de instituciones para toda la Provincia. Como respuesta, va a preconizar, en el orden económico, la privatización de la tierra y, en el orden institucional, el sometimiento de todas las instancias a las instituciones reales, siendo la Real Audiencia de Extremadura la encargada de realizar las transformaciones necesarias ${ }^{102}$.

101 Ibidem, pp. 15-16.

102 Ibidem, p. 16. 


\section{AlFrAnCA, DESTERRAdo EN ZaragOZA ENTRE 1799 y 1810}

La etapa vital más oscura de Alfranca es la de los años entre 1799 y 1810, en la que sólo nos constan dos cosas importantes: sus ingresos económicos y su ordenación sacerdotal.

Después de dejar la magistratura vivió con los 4000 reales anuales de su jubilación forzosa y, además, con una pensión que el rey le había dado sobre la mitra de Cartagena, cuya cantidad no hemos podido concretar. Lo sabemos porque, al recibir las órdenes sacerdotales en Zaragoza (1806-1807) y al participar en la oposición a la canonjía doctoral de Teruel (1810) se hace constar que era «pensionista» o «patrimonialista», lo que le hacía independiente económicamente del arzobispado de Zaragoza, donde, al parecer, residió durante esta década. Además, gozaba del rico patrimonio familiar heredado íntegramente.

Alfranca recibió los órdenes sagrados de manos del obispo Miguel de Santander en 1806 y 1807, su superior jerárquico, más tarde, durante la ocupación francesa de Teruel. En las Témporas de San Mateo, 19 y 20 de septiembre de 1806, recibió «los menores en el palacio Arzobispal y los mayores en el real Seminario sacerdotal de San Carlos de la presente ciudad de Zaragoza», cuando fray Miguel de Santander, «obispo Amizonense103, auxiliar del presente arzobispado», confirió órdenes de Epístola a 28 personas, entre las que se encuentra «don Juan José Alfranca, extradiocesano con dimisorias»104.

A los tres meses recibió el orden de Evangelio de manos del mismo Miguel de Santander, «en los órdenes generales de las Témporas de Santo Tomás, de este año de 1806, en el oratorio del palacio Arzobispal y en el Real Seminario sacerdotal de san Carlos en los días 19 y 20 de diciembre». Entre los 14 orde-

103 Joaquín Matías Suárez, que al profesar como franciscano capuchino adoptó el nombre de Miguel de Santander, había nacido en Santander el 23 de febrero de 1744. El 20 de diciembre de 1802 fue elegido obispo titular de Amyzón (Amizone), auxiliar de Zaragoza. Fue consagrado el 20 de febrero de 1803 en El Pardo por Ramón José de Arce, arzobispo de Zaragoza e Inquisidor General, asistido por Antonio Vila Camps, obispo de Albarracín, y por Francisco Lacuerda, anterior obispo de Puerto Rico. En 1808 fue nombrado por el rey José I, obispo de Huesca, pero no fue confirmado por el papa; tomó posesión, retractándose el 30 de diciembre de 1819. Murió el 2 de mayo de 1831 en Santa Cruz de Iguña (Santander). La documentación relativa a su carrera episcopal, en Hierarchia Catholica Medii et Recentioris Temporis, sive Summmorum Pontificum - S.R.E. Cardinalium Ecclesiarum Antistitum Series e Documentis Tabulariis Preasertim Vaticani Collecta - Digesta - Edita. Volumen Septimum a Pontificatu Pii PP. VII (1800) usque ad Pontificatum Gregorii PP. XVI (1846), per R. Remigium Ritzler -OFMConv. et P. Pirminium Sefrin -OFMCon, Patavii MCMLXVIII, Typis et Sumptibus Domus Editorialis «Il Messagero di S. Antonio, Patavii (Italia), p. 72. Vidal GuITARTE IzQuIERDO, Episcopologio Español (1700-1867), p. 123.

${ }^{104} \mathrm{ADZ}$, Registro de órdenes i dimisorias de la Secretaría de Cámara del Excmo. e Ilustrísimo Sr. D. Fray Joaquín Company, arzobispo de Zaragoza, que da principio en 20 de junio de 1798, fol. 86v. 
nandos seculares encontramos a «don Juan Josef Alfranca, patrimta. [patrimonialista] de Cartagena» ${ }^{105}$.

Dos meses después, el mismo obispo, «celebrando los órdenes generales de la segunda semana de Cuaresma» en la Real Iglesia de San Carlos de Zaragoza, «ordenó de misa» a 21 sacerdotes, siendo el primero «don Juan José Alfranca, penta. (sic. pensionista) de Cartagena». Por lo tanto, Alfranca tenía casi 53 años cuando fue ordenado sacerdote. Era una evidente vocación tardía.

\section{Alfranca, CANónigo Doctoral de Teruel (1810-1817)}

Juan José tuvo la poca fortuna de llegar a Teruel, una ciudad o mejor un pueblo, en la que dominaban unas autoridades eclesiásticas mediocres y envidiosas, en unos tiempos sumamente turbulentos ${ }^{106}$. Le ocasionarán los momentos más amargos de su vida personas como el obispo don Blas Joaquín Álvarez de Palma, noble andaluz de Jerez de la Frontera ${ }^{107}$, o el vicario general y provisor, segundo en la jerarquía eclesiástica, don Francisco Calvo Ruipérez. Éste era un hombre dinámico, de gran extremismo en sus resoluciones y enemigo declarado de Alfranca, que, a causa del carácter irascible, hizo sufrir mucho al Cabildo y al clero ${ }^{108}$.

Cuando comenzó la guerra, el obispo Álvarez de Palma abandonó su diócesis, dejándola en manos de Francisco Calvo Ruipérez. Los franceses entraron por primera vez en Teruel a finales del año 1809 al mando del general Laval, aunque al poco tiempo se retiraron. La segunda ocupación tuvo lugar hacia finales de mayo del mismo año 1810 y debió de durar hasta finales de junio. Entretanto el general Pedro Villacampa (1776-1845) tenía su cuartel en las cercanías de Teruel. Sea lo

\footnotetext{
105 ADZ, Registro de órdenes i dimisorias..., fol. 90v.

106 Conocemos bastante bien este periodo gracias al excelente trabajo de don César Tomás LaGUíA (1959), «La Iglesia de Teruel en la Guerra de la Independencia».

${ }^{107}$ El obispo Blas Joaquín Álvarez de Palma había nacido en Jerez de la Frontera el 29 de enero de 1754. Es estrictamente coetáneo de Alfranca. Elegido el 17 de abril de 1798, fue consagrado obispo titular de Assuras (Assura) y auxiliar de Sigüenza el 17 de junio de 1798 en Madrid (San Isidro) por José Antonio Sáenz Santamaría, obispo de Segovia, asistido por Francisco La Cuerda, anterior obispo de Puerto Rico, y por Atanasio Puyal Poveda, obispo titular de Carystus (Caristo) y auxiliar de Toledo. El 20 de julio fue trasladado a la sede de Albarracín y el 20 de diciembre a la de Teruel. El 19 de diciembre de 1814 fue designado arzobispo de Granada. Falleció el 29 de noviembre de 1837. La documentación relativa su carrera episcopal, Hierarchia Catholica Medii et Recentioris Temporis, sive Summmorum Pontificum - S.R.E. Cardinalium Ecclesiarum Antistitum Series e Documentis Tabulariis Preasertim Vaticani Collecta - Digesta - Edita. Volumen Septimum a Pontificatu Pii PP. VII (1800) usque ad Pontificatum Gregorii PP. XVI (1846), per R. Remigium Ritzler -OFMConv. et P. Pirminium Sefrin -OFMCon, Patavii MCMLXVIII, Typis et Sumptibus Domus Editorialis «Il Messagero di S. Antonio, Patavii (Italia), pp. 64-65, 92, 206, 218, 244, 250, 363. GuITARTE IzQuIERdo, 1992, p. 117.

108 Tomás Laguia, 1959, p. 136.
}

Hispania Sacra, LXI

123, enero-junio 2009, 279-352, ISSN: 0018-215-X 
que fuere, lo cierto es que la ciudad en 1810 había perdido su independencia y las tropas francesas entraban y salían con frecuencia.

El 21 de septiembre de 1810 acordó el cabildo que los ejercicios para la oposición a la canonjía doctoral, vacante por la muerte de don Gabriel Otaño, empezarían el día 28. Tomaron parte en esta oposición don Juan José Alfranca y don Domingo García, siendo elegido el primero, tras brillantes oposiciones, y recibió la colación canónica de manos del provisor Ruipérez el 4 de diciembre ${ }^{109}$. Procedente de la diócesis de Zaragoza, cuya ciudad acababa de sufrir dos terribles asedios, Alfranca habrá de jugar un papel decisivo en los acontecimientos que se siguieron a la dominación francesa de la ciudad de Teruel. El hecho de que Alfranca fuera gobernador del obispado durante la ocupación francesa lo coloca en el primer plano de este periodo histórico (Tomás Laguía 1959, p. 136).

Eran tiempos difíciles, según confesará Alfranca, años después (1813) en su autodefensa:

«No era fácil que, ocupada la capital de Aragón y todo su territorio, Teruel, ciudad abierta y situada en los confines de la Provincia de Valencia, objeto particular de la codicia del enemigo, quedase exenta de la triste suerte que había tocado a los demás pueblos; y, en efecto, sorprendida la ciudad en 19 de enero de 1811 por una gruesa división francesa, fue ocupada y dominada por el estilo de las demás, sin que desde entonces haya faltado guarnición estable» ${ }^{110}$.

Alfranca poseía una cultura nada común. Hablaba perfectamente el francés y el italiano, y estaba dotado de una correcta diplomacia para los negocios más embarazosos. Acostumbrado al sufrimiento por su largo destierro, era de carácter opuesto al del orgulloso Ruipérez, por lo que es natural que no coincidieran. El obispo Álvarez, ausente de Teruel cuando llegó Alfranca, no le conoció más que a través de la correspondencia. Hasta terminada su emigración, tuvo de él un concepto equivocado y muy sesgado a través de las apasionadas informaciones de Calvo Ruipérez ${ }^{111}$.

Es bastante fácil seguir la pista al canónigo doctoral Alfranca, pues esa dignidad catedralicia conllevaba la de ser secretario del cabildo y la redacción de las actas del mismo. El cabildo se reunió en sesión extraordinaria el 12 de febrero de 1811 para tratar el delicado asunto de elegir un nuevo gobernador eclesiástico. El acta dice: "Acordó el Cabildo unánimemente aceptar el gobierno de la diócesis y la administración general de las rentas de la mitra [...]. Pero como

109 Archivo de la Catedral de Teruel (ACT), Actas, t. VI, fol. 300 y siguientes. Tomás LaGUiA, 1959, p. 162.

110 Archivo Diocesano de Teruel (ADT), 2-23. César Tomás Laguia, 1959, p. 164.

111 Tomás LagUia, 1959, pp. 136-137. 
dicho gobierno y administración no pueden llevarse en cuerpo, y conceptuado [...] que la mayor facilidad y expedición de los negocios en uno y otro ramo conviene se designe a un individuo del cabildo en quien éste refunde todas sus facultades, el cual será tal gobernador y administrador por sí y en nombre del ilustrísimo señor obispo, de quien dimana la autoridad en virtud de sus letras de comisión». Hecha votación secreta entre los once canónigos presentes, pues tres se hallaban ausentes, dos impedidos y el deanato estaba vacante, resultó elegido gobernador del obispado, al cuarto escrutinio, Juan José Alfranca, que aceptó el cargo. Seguidamente se acordó comunicarlo al clero de la diócesis para los efectos consiguientes. De todo ello levantó acta, con algunas variantes, el notario D. Juan Gabarda ${ }^{112}$.

Las autoridades francesas de Teruel debieron acoger bastante benignamente al nuevo gobernador de la diócesis, pues se dirigieron siempre a él con absoluta normalidad. Hablaba correctamente el francés y venía a sustituir a un prelado que se había declarado enemigo irreconciliable del invasor.

Como gobernador eclesiástico, tuvo que dialogar repetidas veces con el afrancesado don Agustín de Quinto, comisario general del gobierno de Aragón en la derecha del Ebro, residente en Teruel, el cual cada vez planteaba más exigencias económicas a la ciudad. Cuando la situación de la Iglesia turolense era la más delicada, el cabildo de la catedral de Teruel fue acusado de adhesión a los franceses por el antiguo gobernador del obispado el mal intencionado Francisco Calvo Ruipérez ${ }^{113}$.

ACTUACIONES DEL GOBERNADOR ALFRANCA ENTRE EL 2 DE FEBRERO DE 1811 Y EL 25 DE JUNIO DE 1812

No era fácil dirigir dieciséis meses y medio una diócesis sometida al invasor, pero Alfranca gobernó la de Teruel con la prudencia de un sabio prelado, en medio de no pocos incidentes, producidos por las exigencias del invasor y la falta de tacto de algunos osados eclesiásticos. Como en el resto de España, clero y franceses chocaban por dos grandes divergencias, causadas por el tufillo anticatólico de los herederos de la Revolución francesa (la violenta expulsión de los religiosos de los conventos, la incautación de sus bienes, profanación de lugares religiosos...) y, fundamentalmente, por las contribuciones, cada mayores a medida que el tiempo avanzaba ${ }^{114}$. Tanto la junta municipal como el cabildo de Te-

\footnotetext{
112 Archivó Histórico Provincial de Teruel (AHPT), Protocolos del notario Juan Gabarda, leg. 438 (año 1811), ff. 9r-12r.

113 Tomás Laguia, 1959, p. 175.

${ }^{114}$ Latorre Ciria (1990 y 2006), hablando de la eficacia de la percepción del diezmo en su etapa final, sobre todo a partir de los años iniciales del siglo XIX, afirma, con respecto al obispado de Teruel, 
ruel se vieron atenazados por las crecientes exigencias de los invasores. Eso agriaba las relaciones entre el cabildo y el ayuntamiento afrancesado de Teruel.

Todo, sin embargo, lo iba solucionando el gobernador Alfranca con habilidad y energía. En otras ocasiones su prestigio logró que las autoridades entregasen clérigos rurales a su jurisdicción. Pero lo que más revela sus dotes fue su actuación con el clero de la ciudad. De una parte se enfrentaba con el problema de los religiosos violentamente exclaustrados, a los que fue necesario destinar a servicios parroquiales, contra el parecer del obispo Álvarez de Palma, que hubiera preferido otras soluciones más radicales y menos colaboracionistas con el francés, según manifestó en una de sus cartas al cabildo. De otra parte, el clero de la ciudad, que creía que la hora de la liberación de Teruel estaba próxima, no se recataba de hacer comentarios desfavorables a los franceses en sus paseos por los pórticos de la plaza del mercado y aún en las tertulias particulares, donde concurrían oficiales del ejército de ocupación.

Esto dio lugar a que el general Abbé, comandante del cantón de Teruel, a finales de abril de 1811, dictara una serie de órdenes draconianas, entre ellas la salida de Teruel de muchos clérigos. El gobernador Alfranca consiguió que no se ejecutará esta orden de destierro y para evitar incidentes en lo sucesivo, el 16 de mayo de 1811, circuló una orden a todas las iglesias de la ciudad con las normas que debían observar los eclesiásticos.

Pero las actuaciones del gobernador eclesiástico Alfranca no se reducían a solucionar conflictos con el mando militar francés, sino que también procuró, por todos los medios, la conservación de la disciplina, organizando y presidiendo personalmente las conferencias morales del clero de la ciudad y atendiendo, en lo posible, al Seminario, Casa de Misericordia, etc.

En resumen, Alfranca transigió en cuestiones secundarias y de protocolo, como ciertas formalidades exigidas por la oficialidad del ejército francés, que se presentó como católica, aunque muchos de sus actos no estaban muy en armonía con los sentimientos católicos. Por ejemplo, Alfranca no tuvo inconveniente en que se cantase el Domine, salvum fac imperatorem nostrum Napoleo-

que «no se han hallado testimonios que revelen una resistencia al pago del diezmo a lo largo del período estudiado, aunque puede admitirse que durante los años de la Guerra de la Independencia el desorden causado por la misma debió afectar al diezmo y es posible que tras la misma no se recuperasen por entero las prácticas antiguas. No obstante, también conviene recordar que estamos en una zona interior donde las ideas liberales llegan tarde y donde el carlismo arraigó en las zonas rurales».

En el obispado de Teruel el diezmo estaba fragmentado entre los distintos grupos del clero. Atendiendo al reparto porcentual del diezmo que se deduce de las constituciones sinodales, puede estimarse que, en el plano teórico, un 25,93 por ciento del diezmo diocesano era para el prelado, un 15,07 para el cabildo de la catedral, un 8,26 para el capítulo de racioneros de la ciudad de Teruel, un 27 para el clero rural y el resto para diversas instituciones eclesiásticas. Lógicamente la voracidad impositiva de los franceses se sumó al reparto de esta tarta en tiempos de Alfranca. 
nem al final de ciertas misas solemnes. A lo largo de 1812 el cabildo siguió cumplimentando a las autoridades impuestas por los franceses para evitar mayores males. Una comisión capitular pasó a saludar al mayor Paschali, un italiano que en febrero llegó a Teruel en calidad de comandante de la plaza. Con estas deferencias y atenciones, que en nada ofendían al decoro del templo, Alfranca consiguió evitar muchos males a la iglesia turolense, aunque nos podemos figurar la pésima impresión que causaría al general Pedro Villacampa, por lo demás bastante liberal, y al reaccionario obispo Álvarez de Palma la noticia de la conducta del cabildo, transmitida sin tardanza y con cargadas tintas negativas por el ex-provisor Ruipérez. Pero lo cierto es que la vida religiosa de Teruel y de su diócesis se desenvolvió con toda la normalidad que podía esperarse en tan difíciles tiempos. Durante la ocupación francesa de Teruel se celebraron las procesiones acostumbradas, se hicieron en la catedral algunas reparaciones y los divinos oficios se celebraron en todas las iglesias del obispado como en tiempos normales. Y todo esto se debió a la prudencia del cabildo y del gobernador Alfranca ${ }^{115}$.

Entretanto, el obispo de Teruel continuaba refugiado y seguro en la villa de Pego (Alicante). Desde allí, de vez en cuando, enviaba al cabildo turolense los decretos de las Cortes de Cádiz y otros documentos que, de ningún modo, el gobernador Alfranca podía poner en ejecución. Lo que sí pudo lograrse, con no escaso peligro, es que los seminaristas que deseaban recibir la ordenación fueran a Pego a recibirla de manos de su prelado. El obispo Álvarez celebró órdenes en la iglesia parroquial de Pego, en los días 13 de abril de 1812, 7 y 8 de junio, 14,21 y 25 de julio y 20,21 y 29 de septiembre del mismo año.

PRISIÓN DEL Gobernador EClesiástico AlFRANCA POR TROPAS DEL GENERAL VILLACAMPA

Alfranca no era persona grata a la Junta Superior de Aragón y parte de Castilla, y mucho menos al general Villacampa, por su supuesta cordial convivencia de aquel con los franceses, e influidos también por los informes del ex-vicario Calvo Ruipérez y otros enemigos del gobernador eclesiástico Alfranca. Así, pues, hubo una secreta conjura entre el general Villacampa, que merodeaba por las cercanías de Teruel, y algunos individuos de la ciudad, y en la noche del 25 de junio de 1812, cuando la población se hallaba poco vigilada y deficientemente guarnecida por los franceses, las tropas de Villacampa dieron un golpe de mano sobre Teruel, apresando, entre otros, al gobernador Alfranca, quien confesará más tarde que el provisor Ruipérez fue el causante del proceso que se formó

115 TOMÁs LagUia, 1959, p. 180.

Hispania Sacra, LXI

123, enero-junio 2009, 279-352, ISSN: 0018-215-X 
por la jurisdicción militar, «incompetente para cohonestar el habérseme arrancado clamorosamente de en medio de la grey» (Tomás Laguía 1959, p. 187).

En la sesión capitular del 26 de junio de 1812, al día siguiente de ser apresado, «se leyó una carta del señor Alfranca, dirigida al presidente, para que hiciera presente al cabildo se ausentaba de la ciudad y que no podía desempeñar el gobierno eclesiástico, y que así pasara el cabildo a la designación de otro capitular para su desempeño». No cabe duda que esta misiva la escribía Alfranca en presencia de sus guardianes, con prohibición de decir las causas de su ausencia. El 27 de junio de 1812 se reunió el cabildo en sesión extraordinaria para elegir nuevo gobernador, en virtud de los poderes que le había otorgado el obispo Álvarez el 5 de febrero de 1811. Fue elegido el magistral, don Joaquín López, persona muy competente y bien vista por los franceses, por las comisiones desempeñadas ante el general Suchet.

Por mucho tiempo, nadie supo el paradero de Alfranca. Se sabía que había sido apresado, y el cabildo hizo gestiones en su favor ante el general Villacampa, aunque sin resultados. El mismo interesado referirá, más tarde, que fue «llevado de pueblo en pueblo, entre bayonetas, por más de dos meses», es decir, hasta finales de agosto de 1812 .

\section{El PROCESO CONTRA El GOBERNADOR ALFRANCA}

Tras larga incomunicación pudo, por fin, el doctoral Alfranca escribir al cabildo desde El Villar del Cobo (Teruel), en lo más intrincado de las sierras de Albarracín, el 22 de septiembre de 1812. Entre otras cosas decía:

«Hoy es el primer día, después de 89 de arresto, en que tengo libertad de poder escribir, y mi primer cuidado es participar a vuestra señoría [el cabildo de Teruel] mi situación. Bien notoria ha sido la clase de prisión sufrida con los demás arrestados de esa ciudad, en los 73 días que he estado a la disposición militar hasta el 5 de este mes [septiembre de 1812], que fui conducido a la de este tribunal con el expediente que se empezó a formar por aquella jurisdicción a los 26 días después de mi arresto por pesquisa [ 21 de julio], y en que se me tomó declaración hasta los 68 días [1 de septiembre]. Las incomodidades, privaciones y sonrojos que llevaba consigo tamaña prisión no son para descritos».

Pide que se le apoye en justicia y que se saque certificado de lo que consta en el libro capitular de Gestis, especialmente con relación al destierro del clero de la ciudad que evitó, y a sus gestiones con el comandante Lefebre y con el obispo Santander para que terminase, «sin horrores, el asunto del padre del cura de Santa Eulalia, condenado a muerte, como también en lo relativo a la prisión que se hizo a todos los vecinos que tenían parientes sirviendo en el ejército español» ${ }^{116}$.

116 ACT, 195-2-3. César Tomás Laguia, 1959, pp. 188-189. 
Alfranca, pues, había pasado de una prisión militar a una detención más atenuada en poder de personas civiles, a finales de septiembre de 1812, probablemente a poder de la Junta Superior de Aragón, que por los días que escribe se hallaba en Orihuela del Tremedal (Teruel). Pasaron los meses y el antiguo gobernador eclesiástico continuó sujeto a un proceso formal por sospecha de infidencia ${ }^{117}$. Después de casi un año de prisión, el 9 de junio de 1813, Alfranca escribió al presidente del cabildo de Teruel pidiendo unos documentos, pues, «como mi causa viene a ser indirectamente la causa del clero de nuestra diócesis, espero no extrañará el cabildo que yo le pida un abonatorio de mi conducta eclesiástica y política durante el tiempo que ejercía el gobierno»118.

Pocos días más tarde, el 25 de junio de 1813, al año exacto de su apresamiento, Alfranca ya tiene organizada su defensa. Don Domingo González, vecino de Teruel, como procurador de Alfranca, formalizaba y concretaba la petición de documentos al cabildo, para defensa «de mi parte en el expediente que se le ha formado a consecuencia de arresto y ocupación de su persona que se hizo en la noche del día 24 de junio del año próximo pasado [1812]». Entre otros, pide un testimonio de haber podido reducir a la mitad la exacción de 40.000 reales que se impuso al clero de Teruel en septiembre de 1811, «para satisfacer un pedido militar del general Arispe», y otro atestiguando que mantuvo con esplendor la religión y el culto, favoreció a los religiosos exclaustrados, etcétera.

Liberada Teruel, a principios de julio, volvió Alfranca a escribir desde Zaragoza al cabildo pidiendo las rentas devengadas por su canonjía. Su carta se leyó en la sesión de 3 de septiembre de 1813. El secretario del cabildo, Sr. Becerril, le respondió el día 4, accediendo a su petición, añadiendo «que el Cabildo desea se conserve sin novedad y termine su causa pronta y felizmente» ${ }^{119}$.

\section{SeCuestro de los BIENES DE AlfrancA}

Una de las secuelas más desagradables de la prisión de Alfranca fue el secuestro de sus bienes, incluidos los más personales, los cuales fueron maltratados por gentes aprovechadas y sin escrúpulos durante el año y medio de su retención, cuya restitución dio lugar a la intervención de la Audiencia Territorial de Zaragoza, por dos veces, una antes y otra después de la absolución penal de Alfranca ${ }^{120}$.

117 En el Archivo Histórico Provincial de Zaragoza hay una sección de «Procesos de Infidencias, vistos en la Real Audiencia de Aragón», pero no aparece el que sufrió Alfranca.

118 Tomás Laguia, 1959, p. 189.

119 Ibidem, p. 190.

120 Archivo histórico provincial de Zaragoza (AHPZ), Índice del libro único de registro de provisiones civiles expedidas por la Real Audiencia de Aragón desde el día 20 de agosto del año de 1813 hasta últimos del mismo año. Conocido como Libro de Reales Provisiones, ff. 22r-23r. 
Casi dos meses antes de la vista de la causa, la Audiencia Territorial de Zaragoza ordena levantar el secuestro de los bienes de Alfranca, en Real Provisión del 13 de septiembre de 1813, a «instancia de Don Juan José de Alfranca, de Teruel»:

«Se alza el secuestro de los bienes de don Juan José Alfranca, practicado por los comisionados de la Hacienda pública del partido de Teruel, y se entreguen a él mismo o personas que depute, librándose a el efecto la Real Provisión correspondiente en vista de este expediente» ${ }^{121}$.

Se hace saber el auto al procurador del enunciado don Juan José Alfranca y notificar su contenido «a D. Benito Pereda, comisionado de la Hacienda Nacional, para que disponga se entreguen a don Juan José Alfranca o la persona que dipute, los bienes que se le secuestraron y consta de la copia concordada, firmada de nuestro infrascripto escribano de Cámara, que acompaña a esta nuestra Provisión, a virtud de lo mandado en el asunto arriba inserto» ${ }^{122}$.

Algunos aristócratas locales, como la baronesa de Escriche, creyendo ver definitivamente perdido al doctoral Alfranca, por la grave acusación de afrancesamiento, se atrevieron a saquear sus bienes secuestrados, lo que obligó, justamente indignado, al doctoral a presentar una segunda Instancia, pidiendo que se le devuelvan esos bienes perdidos durante el secuestro. La Audiencia Territorial contestó afirmativamente, tres días después de haberlo absuelto, en una Real Resolución fechada el 13 de noviembre de 1813. Ese mismo día el rehabilitado doctoral comunicaba gozoso su libertad al cabildo turolense ${ }^{123}$.

El recurso que Alfranca presenta por medio de su «procurador legítimo», Mariano Sebastián, muestra la fortaleza moral con que nuestro doctoral salió de su injusto proceso, las miserias de la aristocracia local y la arbitrariedad con que se jugaba con la fortuna de los perseguidos políticos:

«Esta injuria es mucho más sensible a mi principal [Alfranca] que lo sería la pérdida de los efectos que sin razón se ha apropiado la baronesa [de Escriche] a la sombra del decidido favor que le han dispensado los comisionados, y mi principal confundirá las ideas que se traslucen en esta conducta, haciendo constar, a su tiempo, que las seis cortinas de Damasco de que se trata estuvieron en uso de la casa que habitaban los padres de mi principal en esta ciudad [Zaragoza], calle Gabín, hasta fines de 1788, y que las mismas, con las demás ropas ocupadas por la baronesa, han formado, desde dicha época, parte de su equipaje en Sevilla, Cáceres y otras partes donde ha residido» 124 .

\footnotetext{
${ }^{121}$ Ibidem, f. 23 r.

122 Idem.

123 Ibidem, ff. 66r-69r.

124 Ibidem, f. 68.
} 
Ante este convincente razonamiento, la Sala emite un auto en Zaragoza, el 15 de noviembre de 1813, ordenando la devolución de los bienes, que, como suele ocurrir en estos casos, no fue posible cumplir íntegramente ${ }^{125}$.

\section{Don JuAn José DE AlFrAnCA EN LIBERTAD}

En los primeros días de noviembre de 1813 se vio en la Audiencia Territorial de Zaragoza la causa por supuesta infidencia del ex-gobernador eclesiástico de Teruel. El juicio fue público, «con mucho concurso de gente de todas clases», y era natural dada la calidad del acusado. El fiscal fue designado por la Regencia especialmente para esta causa, y como testigos desfilaron muchos eclesiásticos y seglares de Teruel. Generalmente las deposiciones de estos testigos le fueron favorables. Un pequeño grupo, capitaneado por Calvo Ruipérez en persona, acumulaba muchos cargos contra Alfranca. Entre estos últimos testigos figuraba un racionero de Teruel, apellidado Bautista, y su hermano el canónigo magistral de Albarracín. Ninguno de ellos había presenciado los hechos que se le imputaban a Alfranca, ni había residido en Teruel durante el gobierno de aquel (febrero de 1811 a junio de 1812). Las artimañas de Ruipérez volvieron a brillar en esta ocasión.

Alfranca quiso ser su propio defensor y, durante tres mañanas, fue exponiendo los hechos y deshaciendo los argumentos de la acusación con la contundencia y pericia de uno de los doctorales más competentes que ha tenido la iglesia turolense. El resultado fue la sentencia definitiva del 10 de noviembre de 1813, en la que se le concedió la libertad y la facultad de poder regresar a Teruel para servir su canonjía, sin otra pena que la de no poder ejercer el cargo de gobernador del obispado durante un año. Esta sentencia fue comunicada de oficio al cabildo de Teruel el 16 de noviembre por don Juan Garrido, decano presidente de la Audiencia de Zaragoza ${ }^{126}$.

El 13 de noviembre Alfranca escribía al cabildo de Teruel: «Tengo la satisfacción de anunciar a vuestra Ilustrísima que me hallo en libertad, después de haber estado privado de ella dieciséis meses y medio [ 25 de junio de 1812 al 13 de noviembre de 1813]. Para mí es del mayor consuelo el poderme presentar en la residencia, limpio de este borrón, al desempeño de mis obligaciones». Anuncia que irá a Teruel pasados algunos días.

El cabildo le contestó el 24 de noviembre:

«El cabildo, que tenía un verdadero interés en el feliz éxito de la causa que se formó contra vuestra señoría, se ha llenado de satisfacción al leer su apreciable del 13 de los co-

\footnotetext{
125 Ibidem, f. 69r.

126 Tomás Laguia, 1959, p. 203.
} 
rrientes [noviembre de 1813] y se congratula por la terminación de un negocio que pone cubierta de la maledicencia la conducta de vuestra señoría, al paso que le facilita un individuo para el desempeño de las obligaciones de esta Santa Iglesia» (Tomás Laguia, 1959, p. 203).

El 23 de noviembre volvía a escribir Alfranca aconsejando al cabildo que enviara un comisionado a Zaragoza y que le diera poderes para tratar con el intendente del Reino sobre algunas ventajas económicas que habían obtenido otras Iglesias. El cabildo lo aceptó.

No sabemos la fecha del regreso de Alfranca a Teruel, pero la primera vez, después de su encarcelamiento, que firmó las actas capitulares, como secretario que era del cabildo, fue el 10 de enero de $1814{ }^{127}$.

\section{AlfranCA EN 1814}

A lo largo del año 1814 el doctoral Alfranca desarrolla su labor normalmente en el cabildo de Teruel. En marzo de 1814, ante una queja del Ayuntamiento sobre el protocolo de asistencia de los capitulares a la catedral con capas pluviales, el cabildo, el 27 de marzo, envía una contestación redactada por Alfranca en términos tendentes a la armonía. Fue uno más de los incidentes resueltos por él.

En abril de 1814 el rey Fernando VII visitó Teruel, en su viaje desde Zaragoza a Valencia. Previendo la llegada del rey, el doctoral Alfranca consultó a uno de los doctorales de Zaragoza sobre el ceremonial con que el Rey había sido recibido en las catedrales del Pilar y de la Seo, donde asistió a los cultos de la Semana Santa. El día 11 informó al cabildo sobre la respuesta. La estancia de Fernando VII en Teruel fue muy breve, pues llegó el día 13, poco después del mediodía, se hospedó en el Palacio episcopal, dedicó la tarde, tras la comida, a recibir a las autoridades y distintas comisiones, y a visitar la catedral, donde se cantó un solemne Te Deum. Al día siguiente, a las nueve de la mañana, partió la comitiva.

Alfranca pudo ver cómo desaparecían de Teruel sus enemigos. El obispo Álvarez de Palma, el 3 de octubre de 1814, bajó a la sacristía mayor de la catedral para despedirse del cabildo, por haber sido promovido a la silla arzobispal de Granada. El acto, que otras veces daba lugar a una sesión solemne en la sala capitular con discursos, fue de la mayor sencillez. En Teruel dejó como gobernador del obispado a don Francisco Calvo Ruipérez, su vicario general, quien, el 10 de marzo de 1815, ofició al cabildo, acompañando una certificación, emi-

127 ACT, Actas, t. VI, f. 783. 
tida por el secretario capitular de Granada, en la que se daba cuenta de que el 25 de febrero de 1815 se había posesionado de aquel arzobispado Álvarez de Palma. Fue una de las últimas actuaciones de este enemigo acérrimo de Alfranca, pues el 27 fue destituido y el 29 de marzo de 1815 fue elegido nuevo vicario capitular D. Agustín Rubio ${ }^{128}$.

\section{Últimos AÑos DE dON JuAN José DE AlFRANCA y CASTEllote}

Tan pronto como pudo, Alfranca deshizo los entuertos de su enemigo Calvo Ruipérez, gobernador hasta el 27 de marzo de 1815. El 20 de ese mes, cuando el cabildo tenía, de hecho, ya la jurisdicción del obispado, por la posesión de Álvarez del arzobispado de Granada, el 25 de febrero, el doctor Alfranca presentó por escrito una propuesta de anulación de la famosa y terrible circular de Ruipérez del 9 de julio de 1813, con la que suspendió las licencias ministeriales de buena parte del clero, que había obtenido sus plazas en el concurso de provisión de curatos convocado por Alfranca en 1812 y se mandó que la circular fuera inserta en los libros parroquiales para perpetua memoria. En ella había frases durísimas contra Alfranca. Cuando el obispo Álvarez regresó a Teruel recibió la protesta del cabildo y de otros eclesiásticos por aquella circular y prometió que pondría remedio; mas como no lo hizo, el doctoral Alfranca pide ahora que se mande recoger y borrar de los libros y que se considere nula e injuriosa al cabildo. Éste acordó que así se hiciera. En efecto, se envió a todas las iglesias un decreto del cabildo expedido el 22 de marzo de 1815 en el sentido indicado ${ }^{129}$.

En 1815 Alfranca estaba totalmente rehabilitado políticamente y era un hombre importante del Cabildo, el cual le encargaba comisiones relacionadas con el ramo económico, lo cual denota que confiaba en sus buenas dotes de administrador. El 29 de noviembre de 1815 es nombrado conservador en la Junta de $\operatorname{propios}^{130}$.

Alfranca estaba ganando la batalla legal y moral, pero había perdido la salud con los trabajos sufridos en la lucha con sus superiores. Desde Las Cuevas de Cañart, pueblo de donde descendía su madre y donde se hallaba enfermo, comunicó al cabildo el 5 de agosto de 1815 que había sido nombrado por su majestad juez colector de anualidades y vacantes eclesiásticas en este obispado. Era la prueba de que se hallaba completamente rehabilitado ante el gobierno de Fernando VII. El 16 de septiembre envió un certificado médico desde el mismo pueblo. Volvió de nuevo a Teruel, pero su actuación fue muy limitada, fallecien-

\footnotetext{
128 TOMÁs LagUia, 1959, p. 217.

129 Ibidem, p. 216.

130 AHPT, Protocolos del notario Juan Gabarda, legajo número 50 (año 1815), ff. 218r-219v.
} 
do a mediados de abril de 1817131 . Alfranca firma su última acta, como secretario del cabildo, el 24 de mayo de 1816, y el 21 de junio se nombró un nuevo secretario por enfermedad del canónigo doctoral ${ }^{132}$.

Si consideramos que falleció el 14 de abril de 1817, la última enfermedad de Alfranca debió durar casi un año, desde junio de 1816 hasta abril de 1817, aunque en agosto de 1815 ya veraneaba enfermo. No sabemos dónde falleció, pues según nos asegura el canónigo archivero de Teruel, don Pedro Hernández Izquierdo, no está enterrado en la catedral de Teruel, por lo que suponemos que tal vez muriese en el pueblo de su madre, Las Cuevas de Cañart, en la soledad del Maestrazgo.

La herencia materna de Alfranca en Las Cuevas debía ser considerable, pues además de poseer una cómoda residencia, donde veranear y donde seguramente murió, había vendido una masada y una finca, el 23 de mayo de $1812^{133}$. Venta importante por el precio, pero que no supuso su alejamiento de Las Cuevas y sus alrededores, donde mantenía bastantes amigos. Tampoco sabemos las causas de la venta, pues es difícil imaginarse que la máxima autoridad del obispado tuviese necesidades perentorias que lo impulsasen a ella en el calamitoso y hambruno año de 1812 .

Alfranca todavía tuvo la satisfacción, antes de morir, de ver la solución del concurso de curatos, cuando sus enemigos, el obispo Álvarez de Palma y el provisor Calvo Ruipérez, habían desaparecido de la diócesis.

El doctoral Alfranca, batallador personaje, regresó al cabildo victorioso, a mediados de enero de 1814. El 1 de febrero de ese año envió a la Real Cámara una larga exposición, canónicamente bien argumentada, de los hechos que precedieron y siguieron a la celebración del concurso de 1812. Habla del éxito de su gestión y hace notar, con orgullo, que «se haya contenido y templado la ejecución de vejaciones, destierros, procesamientos y prisiones intimadas muchas veces por el gobierno intruso contra eclesiásticos, verificándose lo que, tal vez, no podrá contar territorio alguno de España, a saber, que ningún clérigo ni aún seglar de la diócesis haya sido fusilado ni conducido a Francia». Había salvado «las rentas de la mitra, no obstante estar confiscadas por la emigración del prelado», y las había «sustraído a la codicia del enemigo». Refuta una a una las razones aducidas contra la validez del concurso de curatos y termina con una muestra de su perspicacia. No pide la anulación del nuevo concurso, sino solamente que sea reconocido como concursillo del primero y que los opositores de 1812 tengan derecho preferente a las plazas vacantes entonces ${ }^{134}$.

131 ACT, Actas, t. VII, f. 94v.

132 Ibidem, f. 81.

133 AHPT, Protocolos del notario Juan Gabarda, legajo número 438 (año 1812), ff. 79r-79v. Escritura de venta de varios bienes en Castellote el 23 de mayo de 1812.

134 Tomás Laguia, 1959, p. 206. 
El Supremo Tribunal de la Cámara, el 18 de septiembre en 1815, pasó al nuevo obispo de Teruel, don Felipe Montoya y Díez ${ }^{135}$, los expedientes de los concursos hechos por Alfranca en 1812 y por el obispo Álvarez en 1813, a fin de que los solucionara de acuerdo con las nuevas normas. A su vez, el prelado Montoya, que se hallaba en Madrid, el 8 de noviembre los envió a los gobernadores del obispado de Teruel, don Joaquín López y don Vicente Rubio y Musoles. Los dos le aconsejaron, en carta del 5 de febrero de 1816, que formara con ambos concursos uno solo, dándoles validez «de manera que, vistas las censuras de los jueces sinodales de uno y otro, y de los méritos de los respectivos opositores y de las demás cualidades de ellos, formase vuestra Señoría Ilustrísima las ternas, sin consideración a si los propuestos por vuestra Señoría Ilustrísima eran del primero o segundo concurso».

Este sabio consejo, que coincidía con las tesis de Alfranca, fue aceptado por el obispo Montoya, y el 17 de febrero de 1816 lo aprobaba con un decreto en Teruel. De este modo terminó este enojoso asunto que tanto había quebrantado la paz de la diócesis turolense y la salud de Alfranca ${ }^{136}$.

\section{CONCLUSIÓN}

De la narrada peripecia vital de Alfranca, aparecen claros los rasgos constantes de su personalidad, caracterizada por su reformismo cristiano e ilustrado. Comparando las innovaciones pedagógicas del rector Alfranca con las socioeconómicas que propone en el informe general y en los particulares de cada pueblo «visitado» del Partido de Llerena, vemos que coinciden fundamente con la racionalidad del pensamiento que, por otra parte, el regente Arias Mon manifiesta en las distintas representaciones que a lo largo de la década de 1791-1799 se vio precisado a dirigir al Consejo de Castilla, ante las muchas dificultades que se fue encontrando para implantar la Audiencia, cuya cruda realidad ya había sido enunciada en la utopía del Discurso de apertura, redactado por el poeta Meléndez Valdés.

135 Felipe Montoya había nacido el 28 de abril de 1753 en Grijota, diócesis y provincia de Palencia. Elegido obispo el 10 de julio de 1815, fue consagrado el domingo, 1 de octubre, en la iglesia de Nuestra Señora de la Merced, por Gregorio Ceruelo La Fuente, obispo de Oviedo, asistido por Manuel Benito Tabernero, obispo de Solsona, y por Blas Jacobo Beltrán, obispo de Coria. Falleció el 12 de marzo de 1825 en Valencia. La documentación relativa a su carrera episcopal, en Hierarchia Catholica Medii et Recentioris Temporis, sive Summmorum Pontificum - S.R.E. Cardinalium Ecclesiarum Antistitum Series e Documentis Tabulariis Preasertim Vaticani Collecta - Digesta - Edita. Volumen Septimum a Pontificatu Pii PP. VII (1800) usque ad Pontificatum Gregorii PP. XVI (1846), per R. Remigium Ritzler -OFMConv. et P. Pirminium Sefrin -OFMCon, Patavii MCMLXVIII, Typis et Sumptibus Domus Editorialis «Il Messagero di S. Antonio, Patavii (Italia), pp. 283, 341 y 363

136 Tomás Laguia, 1959, p. 218.

Hispania Sacra, LXI

123, enero-junio 2009, 279-352, ISSN: 0018-215-X 
Pensamos, como escribimos hace más de diez años en un trabajo que ha pasado tan desapercibido como el empeño que pusimos en su redacción (Astorgano, 1997), que el núcleo del pensamiento reformista que se intentaba implantar en Extremadura a través de la institución de la Audiencia tenía raíces aragonesas (Mon, Alfranca y Meléndez Valdés), claramente insertadas, como es lógico, en los planes de Campomanes, el protector de los tres, a quien estaban ligados por diferentes motivos, el principal su profundo amor hacia Extremadura y su veneración por el fiscal asturiano. Campomanes eligió a Arias Mon como regente por sus conocimientos de la administración de la Justicia, demostrados en la Real Audiencia de Aragón, y por su política reformista constatados al frente de la Sociedad Económica Aragonesa (1784-1790). Juan José Alfranca fue sacado de su alcaldía del crimen de Sevilla por su capacidad organizativa y su regalismo, demostrado al frente del Colegio de Españoles de Bolonia, cuya gestión le era directamente conocida porque fue el centro de estudios elegido por Campomanes para la formación de sus sobrinos.

Destituido Campomanes, incluso antes de leerse el Discurso de apertura, la Audiencia de Cáceres y los magistrados Alfranca y Meléndez perdieron un gran valedor y empezaron las dificultades de la diaria y cruda realidad que el nuevo hombre fuerte de la vida política española, Manuel Godoy, intentó solucionarlas desde otras perspectivas, quitando protagonismo a la Audiencia.

Meléndez Valdés y Alfranca no pudieron desarrollar su reformismo ilustrado en la década 1798-1808. Se lo impidió su enemigo, el ministro de Gracia y Justicia, José Antonio Caballero. Ambos reemprendieron las tareas reformistas en plena Guerra de la Independencia con la mejor intención y rectitud de criterio. Las terribles circunstancias de la guerra civil, pues eso fue esencialmente la Guerra de la Independencia, llevó a Meléndez al destierro y al antiguo rector de Bolonia, magistrado de Cáceres y doctoral de Teruel, a la cárcel. Los dos fueron destacados universitarios y magistrados regalistas. El paralelismo vital entre ambos, notable desde el punto de vista profesional e ideológico, es asombroso en el plano cronológico, pues nacen en marzo de 1754 y mueren en abril-mayo de 1817, el mismo mes del mismo año.

\section{BIBLIOGRAFÍA}

Alfranca y CAStellote, J. J. (1791). Interrogatorio de la Real Audiencia. Extremadura a finales de los tiempos modernos. Partido de Llerena, (1791), Mérida, Asamblea de Extremadura.

Alfranca y CAStellote, J. J. (1814). «Sobre provisión de nueve curatos, cuyo concurso anuló el reverendo obispo de Teruel y formó y convocó otro de nuevo para ello. Se oponen los párrocos que fueron nombrados y el gobernador 
que fue del obispado», en Archivo Histórico de la Diócesis de Teruel, Leg. 984, ff. 1-12.

Astorgano Abajo, A. (1995). «Juan Meléndez Valdés en la Real Sociedad Económica Aragonesa», Revista de Estudios Extremeños, Tomo LI, número I, Enero-Abril, 1995, pp. 103-175.

Astorgano Abajo, A. (1996). Biografía de D. Juan Meléndez Valdés, Diputación de Badajoz, Colección «Biografías Extremeñas», Badajoz, 1996, 585 pp.

Astorgano Abajo, A. (1997). «Las referencias aragonesas del Discurso de apertura de la Real Audiencia de Extremadura», Revista de Estudios Extremeños, Tomo LIII, número I, Enero-Abril, 1997, pp. 75-155.

Astorgano Abajo, A. (1998a). «El fracaso de la generación de los ilustrados», Historia y vida, Número 365/ año XXXI/ agosto, Barcelona 1998, pp. 12-27.

Astorgano Abajo, A. (1998b). «El abate Vicente Requeno y Vives (17431811) en la Real Sociedad Económica Aragonesa (1798-1801)», Rolde. Revista de cultura aragonesa, n. $^{\circ} 85-86$ (julio-diciembre de 1998), Año vigésimosegundo, Zaragoza, 1998, pp. 56-73.

Astorgano Abajo, A. (1998c). «Encuentro del Padre Arévalo con el inquisidor jansenista, Nicolás Rodríguez Laso, en la Italia de 1788», Real Academia de Extremadura de las Letras y las Artes, El Humanismo Extremeño. Estudios presentados a las Segundas Jornadas organizadas por la Real Academia de Extremadura en Fregenal de la Sierra en 1997, Trujillo, 1998, pp. 381-401.

Astorgano Abajo, A. (1999a). «El paso de Jovellanos y Meléndez Valdés por el Ministerio de Gracia y Justicia (1798)», Revista de Estudios Extremeños, Tomo LV, número III, Septiembre-Diciembre, 1999, pp. 995-1052.

Astorgano Abajo, A. (1999b). «La personalidad del ilustrado Don Nicolás Rodríguez Laso (1747-1820), inquisidor de Barcelona y Valencia», Revista de la Inquisición de la Universidad Complutense, n. $^{\circ} 8$ (año 1999), pp. 119-190.

Astorgano Abajo, A. (2003). «Godoy y Meléndez Valdés en la Salamanca de 1805-1808», en Manuel Godoy y su tiempo. Congreso internacional Manuel Godoy (1767-1851). Mérida, Editora Regional de Extremadura, Tomo II, pp. 161-211.

Astorgano Abajo, A. (2003b). «El mecenazgo literario de Campomanes y los jesuitas expulsos», en Congreso Internacional Campomanes (1723-1802), Instituto Feijoo del Siglo XVIII, Oviedo, pp. 269-311.

Astorgano Abajo, A. (2004a). «Juan Meléndez Valdés, humanista», Revista de Estudios Extremeños, 2004, Tomo LX-I, pp. 289-400.

Astorgano Abajo, A. (2004b). Edición anotada de Juan Meléndez Valdés, Obras Completas, Edición, introducción, glosario y notas de Antonio Astorgano Abajo, Madrid, Ediciones Cátedra, Bibliotheca Áurea. 
Astorgano Abajo, A. (2005a). «El oidor Juan José Alfranca y Castellote (1754-1817), «visitador» del Partido de Llerena (1791)», Torre Túrdula n. ${ }^{\circ} 11$ (Llerena, julio 2005), pp. 12-13.

Astorgano Abajo, A. (2005b). «Esteban Meléndez Valdés y la formación de su hermano Batilo», en Juan Meléndez Valdés y su tiempo (1754-1817). Actas del Simposio Internacional celebrado en Cáceres en noviembre de 2004, Mérida, Editora Regional, 2005, pp. 17-56.

Astorgano (2006a), «Introducción» a Nicolás Rodríguez Laso, Diario del viage a Francia e Italia (1788), Zaragoza, Institución «Fernando el Católico» / Real Sociedad Económica Aragonesa de Amigos del País.

Astorgano Abajo, A. (2007a). Biografía de D. Juan Meléndez Valdés, el Ilustrado, Badajoz, Diputación de Badajoz, Colección «Biografías Extremeñas», $2^{\text {a }}$ edición corregida y muy aumentada.

Astorgano Abajo, A. (2007b). «Juan Meléndez Valdés: 250 años de pervivencia del hombre y de la obra de un ilustrado en tiempos de turbulencias», $R e$ vista de Estudios Extremeños, Badajoz (Año 2007, tomo I), pp. 293-350.

Astorgano AbAjo, A. (2008). «Introducción» a Vicente REQUENO Y ViVES, Escritos filosóficos: "Ensayo filosófico sobre los caracteres personales dignos del hombre en sociedad». "Libro de las sensaciones humanas y de sus órganos». Edición crítica, introducción y notas de Antonio Astorgano Abajo, Zaragoza, «Clásicos Aragoneses Larrumbe».

Batllori, M. (1971). «El Colegio de España en Bolonia a fines del siglo XVIII». El Cardenal Albornoz y el Colegio de España, Evelio Verdera (Edit.), Zaragoza, Vol. II, pp. 639-669.

Bertrán Roigé, P. (1979). Catálogo del Archivio del Colegio de España, Bolonia, «Studia Albornotiana», XL, Publicaciones del Real Colegio de España.

Castán Esteban, J. L. (2002), Pastores turolenses. Historia de la trashumancia aragonesa en el Reino de Valencia durante la época foral moderna, Zaragoza, REA/CEDDAR.

Froldi, Rinaldo (1981). «El Colegio de España de Bolonia y la literatura española», en Actas del VII ${ }^{\circ}$ Congreso de la A.I.H. (Venecia 25-30 de Agosto de 1980), Roma, pp. 125-151.

Guitarte IzQuiERdo, Vidal (1992). Episcopologio Español (1700-1867), Castellón de la Plana, Ayuntamiento.

JimÉnez CATAlán, M. (1925). Memorias para la historia de la universidad de Zaragoza. Obra premiada por el patronato Villahermosa-Guaqui en el concurso público de 1920-1921, Zaragoza, Tipografía la «Académica» de F. Martínez, calle Ginecio 3. 
Latassa, F. (1802). Biblioteca de escritores aragoneses, Pamplona, 1802, t. VI, p. 271.

LAtORRe CiRia, J. M. (1990). «El reparto del diezmo en la diócesis de Teruel (siglo XVII)», Studium. Geografía. Historia. Arte. Filosofía (Teruel), 2, pp. 27-44.

Latorre Ciria, J. M. (1991). «El clero del obispado de Teruel en 1753», Aragonia Sacra (Zaragoza), VI, pp. 113-149.

LATORRE CiRiA, J. M. (2007). «La producción agraria en el sur de Aragón (1660-1827)», Historia Agraria, 41 (Abril 2007), pp. 3-30.

Llopis Agelán, E. (1980). Las economías monásticas al final del Antiguo Régimen en Extremadura, Madrid, Universidad Complutense de Madrid.

Pérez Martín, A. (1979). Proles Aegidiana, Bolonia, «Studia Albornotiana», Publicaciones del Real Colegio de España, vol. XXXI/3, pp. 1708-1711.

REQueno y Vives, V. (1784). Saggi sul ristabilimento dell'antica arte de' greci, e de' romani pittori, del signor Abate don Vincenzo, Accademico Clementino, Venecia, Giovanni Gatti, en 8. mayor, 40 más 215 pp.

REQUENO Y Vives, V. (2008). Escritos filosóficos: «Ensayo filosófico sobre los caracteres personales dignos del hombre en sociedad». «Libro de las sensaciones humanas y de sus órganos». Edición crítica, introducción y notas de Antonio Astorgano Abajo, Zaragoza, «Clásicos Aragoneses Larrumbe».

RodríGuez BECERRA, S. (1994). «Mirada de un ilustrado a la sociedad extremeña a finales del siglo XVIII», «Introducción» a Interrogatorio de la Real Audiencia. Extremadura a finales de los tiempos modernos. Partido de Llerena, Mérida, Junta de Extremadura.

Tomás Laguía, C. (1959). «La Iglesia de Teruel en la Guerra de la Independencia». Revista de Teruel,.$^{\circ}{ }^{\circ}$ 21, pp. 135-221.

\section{APÉNDICE DOCUMENTAL}

Documentos Relacionados CON la familia DE Alfranca

Acta de matrimonio de la única hermana de Juan José Alfranca. 16 de agosto de $1772^{137}$

«El doctor don José Broto con doña Joaquina Alfranca. En la ciudad de Zaragoza, a 16 días del mes de agosto de 1772, habiendo precedido una sola mo-

137 Archivo Diocesano de Zaragoza. Parroquia de San Nicolás de Bari. Libro de casados (año 1738-1786), f.

Hispania Sacra, LXI

123, enero-junio 2009, 279-352, ISSN: 0018-215-X 
nición de las tres que previene el santo Concilio de Trento, dispensadas las dos por justas causas y advertidas al pueblo en las iglesias parroquiales de San Gil y en esta de San Nicolás de Bari de dicha ciudad, por comisión especial y cual derecho se requiere, dada en 13 días del referido mes de agosto por el Sr. Doctor Quadra, vicario general de este arzobispado, testificada por Miguel Ausejo, notario de dicha curia, al señor doctor don Pablo Castillo, canónigo del Santo metropolitano templo de dicha ciudad, y con dicha licencia, a presencia del infraescrito regente, la jura y testigos, abajo nombrados, casó por palabras legítimas y de presente en las casas de la habitación de don Salvador Alfranca, al doctor don José Broto, mancebo, abogado de los Reales Consejos, hijo de don José y Doña Orosia Comas, natural del lugar de Abanies, diócesis de Huesca, residente en Zaragoza y parroquia de San Gil, y a Dña. Joaquina Alfranca, dama moza, hija de don Salvador Alfranca y Doña Josefa Castellote, natural y residente en esta ciudad y parroquiana de la dicha de San Nicolás, habiéndoles preguntado y entendido su mutuo consentimiento, hallándose presentes y por testigos el doctor don Josep Berne y el doctor don Faustino Hacha, canónigos del referido santo templo y otros muchos. Se confesaron y comulgaron y fueron examinados en la doctrina cristiana, y por ser así, lo firmo dicho día, mes y año arriba calendados. Licenciado don Miguel Arilla, regente [rúbrica].

Doctor don Pablo Castillo Larroy y les dije la misa nupcial» ${ }^{138}$.

\section{Acta del fallecimiento de la hermana de Juan José Alfranca. 5 de di- ciembre del año $1775^{139}$}

«Dña. Joaquina Alfranca, mujer de don José Broto, abogado de los Reales Consejos, murió en el día 5 de diciembre del año 1775, habiendo recibido los santos sacramentos. Y se enterró en esta iglesia parroquial de San Nicolás de Bari a tres actos en el presbiterio frente a la capilla de mi señora Santa Ana, en el día 7 de los dichos mes y año. Hizo testamento en el día 5 de dicho mes y año [diciembre de 1775], que lo testificó don Antonio Bernués, notario del número de esta ciudad de Zaragoza. Ejecutores el referido su marido, don Salvador Alfranca, Dña. Josefa Castellote, padres de la difunta, don Juan Alfranca, hermano de la misma, don José Alfranca, tío, don José Berne, canónigo magistral de la Santa iglesia metropolitana de la dicha ciudad, don Pablo Castillo Larroy, ca-

138 Archivo Diocesano de Zaragoza. Parroquia de San Nicolás de Bari. Libro de casados (año 1738-1786), ff. 179v-180r.

139 Archivo Diocesano de Zaragoza. Parroquia de San Nicolás de Bari. Libro de muertos (17381786). Año 1775 , f. 278 r. 
nónigo de la misma y don Joaquín Langa, abogado de los Reales Consejos. Y para que conste, firmo ut supra. Mosen Joseph Conchillo, regente» ${ }^{140}$.

\section{Testamento de D. Salvador Joseph de Alfranca, Zaragoza 12 de marzo de $\mathbf{1 7 8 7} 7^{141}$}

«En Zaragoza, a doce días del mes de marzo del año 1787.

Que yo, el doctor don Salvador Alfranca, abogado de los Reales Consejos, marido y conjunta persona de Doña Josefa Castellote, vecina de la ciudad de Zaragoza, estando enfermo, pero por la misericordia de Dios en mi buen juicio, firme memoria y palabra manifiesta, revocándolo y anulando, como revoco y anulo todos cualesquiera testamento etcétera, ahora de mi buen grado, etc, certificado, etc, hago y ordeno el presente mi último testamento, última voluntad, ordinación y disposición de todos mis bienes, así muebles como sitios, etc, en la forma siguiente:

Primeramente creo el misterio de la Santísima Trinidad, etc.

Ítem, quiero que mi cuerpo sea enterrado en eclesiástica sepultura y que en mi entierro funeral, misas y demás funciones se gaste aquella cantidad que pareciere a mí muy amada mujer doña Josefa Castellote.

Ítem, mando se paguen todas mis deudas aquellas, etc.

Ítem, dejo de limosna al santo Hospital Real y General de Nuestra Señora de Gracia de dicha ciudad veinte reales de plata. por una vez.

Ítem, dejo por parte y derecho de legítima herencia en dichos mis bienes y hacienda al doctor don Juan José Alfranca y Castellote, mi hijo y de la citada Dña. Josefa Castellote, rector del Colegio Real y Mayor de Españoles de San Clemente de Bolonia.

Al póstumo o póstuma, póstumos o póstumas de que la referida mi mujer ahora o en lo sucesivo pueda estar embarazada, si a luz prevendrán, y a cualesquier parientes míos deudos y personas otras que para el derecho de legítima herencia en dichos mis bienes y hacienda pudieren pretender o alcanzar, diez sueldos jaqueses a cada uno por una vez, la mitad por bienes muebles y la otra mitad por bienes sitios, con los cuales quiero y mando se den por contentos, etc.

Ítem, dejo, de gracia especial, a dicha mi mujer, Doña Josefa Castellote, el dinero que se encontrase en mi casa al tiempo de mi muerte y cualesquiere can-

140 Archivo Diocesano de Zaragoza. Parroquia de San Nicolás de Bari. Libro de muertos (17381786). Año 1775 , f. 278 r.

141 AHNZ, Notario Nicolás Bernués, protocolo 5668, año 1787, ff. 64r-65r.

Hispania Sacra, LXI

123, enero-junio 2009, 279-352, ISSN: 0018-215-X 
tidades que se me debieren y me pertenecieran de frutos y efectos, y por cualesquiera otro motivo para que haga de ello a su voluntad.

Ítem, satisfecho, pagado y cumplido lo sobredicho, de todos los demás bienes míos que quedaren, así muebles como sitios, etcétera, a los cuales etc. dejo, hago e instituyo en heredera mía universal fideicomisaria a Doña Josefa Castellote, mi mujer, con la precisa obligación de haber de disponer la tercera parte de los bienes de que se compone mi universal herencia a dicho don José Alfranca y Castellote, nuestro hijo, cuando tomare estado, y de las dos partes restantes cuando le pareciere a la expresada de Doña Josefa Castellote, mi mujer, a quien le concedo facultad de vender, empeñar y en otra cualquiera manera enajenar los bienes de dichas dos terceras partes, haciéndolo con dictamen y consejo del doctor don Faustino de Hacha, canónigo de la Santa iglesia metropolitana de esta ciudad, y del doctor don José Broto, mi yerno, abogado de los Reales Consejos, vecino de dicha ciudad.

Ítem, nombro en ejecutores del presente mi último testamento y en exoneradores de mi alma y conciencia a la dicha Doña Josefa Castellote, mi mujer, a los citados doctores don Faustino de Acha, y don José Broto, al doctor don Juan José Lasala, racionero penitenciario del Santo Templo de El Salvador, y don Clemente Tarazona, beneficiado de la parroquial iglesia de San Juan el Viejo de dicha ciudad de Zaragoza, a los cuales, conformes o a su mayor parte, doy todo el poder y facultades que a ejecutores testamentarios etc. Quiero que la referida mi mujer dé a los enunciados don Faustino de Acha y don José Broto, mis ejecutores, y a don a Doña Josefa Garcés, mujer del citado don José Broto, una alhaja a cada uno para que me encomienden a Dios. Este es mi último testamento, última voluntad, ordinación y disposición de todos mis bienes, así inmuebles como sitios, etcétera, el cual quiero valga por tal o por codicilo o por cualquiera otra última voluntad que, según fuero de Aragón, derecho o en otra manera más pueda y debe valer. Fiat large.

Testigos: el doctor don Joaquín Pascual y don Nicolás Pascual, residentes en dicha ciudad de Zaragoza. Doctor Joaquín Pascual soy testigo de lo dicho y firmo por don José Salvador Alfranca, testador, que dijo no poder escribir. Don Nicolás Pascual, soy testigo de lo dicho y firmo por don José Salvador Alfranca, testador, que dijo no poder escribir.

Atesto no hay que salvar según fuero de Aragón.

Bernués» ${ }^{142}$.

142 AHNZ, Notario Nicolás Bernués, protocolo 5668, año 1787, ff. 64r-65r. 


\section{Testamento de la madre de Juan José Alfranca. Zaragoza, 20 de agosto de $1791^{143}$}

«En Zaragoza, dicho día 20 de agosto de 1791, que yo, Doña Josefa Castellote, viuda del doctor don Salvador José de Alfranca, abogado de los Reales Consejos, vecina de la ciudad de Zaragoza, estando enferma, pero por la Misericordia y Dios en mi buen juicio, firme memoria y palabra, manifiesta:

Revocando y anulando, como revoco y anulo todos y cualesquiera testamento, etc., ahora de mi buen grado, etc., certificada de todo mi derecho, hago y ordeno el presente mi último testamento, última voluntad, ordinación y disposición de todos mis bienes, así muebles como sitios, créditos, derechos, procesos, instancias y acciones donde quiere habidos y por haber, y de los de la universal herencia del dicho mi difunto marido, en la forma siguiente:

Primeramente, creo el misterio de la Santísima Trinidad, etc.

Ítem, mando que cuando yo muriere sea mi cuerpo enterrado en la parroquial iglesia donde acaeciere mi muerte con el hábito de nuestra Señora del Carmen, haciéndose entierro regular y sin pompa alguna y que por mi alma se celebren prontamente 200 misas rezabas y treinta más por las almas de mi marido, don Salvador de Alfranca, de sus hermanos don Antonio y don José Alfranca, y de mi hija Dña. Joaquina Alfranca y Castellote, con la caridad en los conventos y por las personas que dispusieren mis ejecutores infraescritos o su mayor parte.

Ítem, dejo de limosna de 24 reales de plata de a dieciséis cuartos, por una vez, al santo Hospital Real y General de Nuestra Señora de Gracia de dicha ciudad.

Ítem, mando se paguen todas mis deudas.

Ítem, dejo para ornamentos de la parroquial iglesia de la Villa de las Cuevas de Cañart las basquiñas negras de seda que tenga al tiempo de mi muerte, y dispongo que las ropas y vestidos inferiores de mi uso se distribuyan en las criadas que me sirven y se hallen en mi casa y compañía al tiempo de mi fin y muerte, cuya distribución ha de ser a discreción y conocimiento de Doña Josefa Garcés, mujer legítima del doctor don José Broto, mi yerno ${ }^{144}$.

Ítem, en atención a que, por los respetos debidos a mi difunto padre, aunque sin obligación de justicia, he asistido y alimentado, según lo han permitido mis facultades, a la viuda Teresa Molinero, encargo a mi heredero, abajo nombrado

143 Archivo Histórico de Protocolos de Zaragoza, Notario Nicolás Bernués, protocolo 5672, año 1791 , ff. 401r-402r.

144 José Broto estuvo casado en primeras nupcias con Joaquina Alfranca, fallecida en 1775, y posteriormente lo hizo con Josefa Garcés.

Hispania Sacra, LXI

123, enero-junio 2009, 279-352, ISSN: 0018-215-X 
[Juan José Alfranca] le continué en las asistencias que pudiere, pero esto se entiende por puro encargo mío y sin obligación que le imponga, en virtud de la cual pueda ser compelido en justicia, aunque espero lo hará voluntariamente.

Ítem, dejo por parte y derecho de legítima herencia en todos mis bienes y hacienda a don Juan José Alfranca y Castellote, mi hijo, del Consejo de su majestad y su oidor de la Real Audiencia de Cáceres, y a cualquier parientes míos, deudos y otras personas que para su derecho a legítima herencia en dichos mis bienes y haciendas hubieren pretender o alcanzar, 10 sueldos jaqueses a cada uno por una vez, la mitad por bienes muebles y la otra mitad por bienes sitios, con los cuales quiero y mando se den por contentos, satisfechos y pagados de todo cuanto en dichos mis bienes y universal herencia pudieren pretender o alcanzar en cualquier manera.

Ítem, satisfecho, pagado y cumplido todo lo sobre dicho, de los demás bienes míos y de los de la herencia de mi difunto marido, don Salvador José de Alfranca, usando de las facultades que me confirió en su último testamento, que quiero aquí tener por calentado debidamente y según fuero de Aragón, en la forma más conveniente, dejo, hago, instituyo y nombro en heredero mío universal a dicho don Juan José de Alfranca y Castellote, mi hijo legítimo y del citado mi difunto marido, para que haga y dispondrá de todos ellos a su libre voluntad como bienes propios con justo título adquiridos.

También nombro en ejecutores del presente mi último testamento y exoneradores de mi alma y conciencia a don José Ariño y don Joaquín Langa, mis primos, al dicho doctor don José Broto, mi yerno, abogado de los Reales Consejos. Al doctor don Juan José Lasala, racionero penitenciario del Santo Metropolitano Templo del Salvador de la referida ciudad. Al doctor don Tomás Muñoz, canónigo de la Santa Iglesia Metropolitana Cesaraugustana. A don Juan Muñoz, su hermano, presbítero beneficiado de la parroquial iglesia de San Pablo de dicha ciudad, y a Don Clemente Tarazona, presbítero, beneficiado de la parroquia de San Juan el Viejo de la misma ciudad.

A los cuales, etcétera. Este es mi último testamento, última voluntad, ordinación y disposición de todos mis bienes, y a los de la universal herencia del prenombrado mi marido, muebles y sitios, etc. Fiar large, etc.

Josefa Castellote, otorgo lo dicho.

José Sesé, soy testigo de lo dicho.

Narciso Sanjuán, soy testigo de lo dicho ${ }^{145}$.

145 Archivo Histórico de Protocolos de Zaragoza, Notario Nicolás Bernués, protocolo 5672, año 1791 , ff. 401r-402r. 


\section{Muerte de la madre de Juan José de Alfranca. Zaragoza, 3 de enero de 1797146}

«Dña. Josefa Castellote, viuda de D. Salvador Alfranca, murió en esta parroquia de San Nicolás de Bari el día 3 de enero del año de 1797 y se enterró a tres actos en el presbiterio de la referida parroquia el día 4 del sobredicho mes y año, y la enterró, con el beneplácito del infraescrito cura párroco, el Sr. D. Tomás de Arias, canónigo de la Santa iglesia metropolitana de Zaragoza ${ }^{147}$. Se confesó, recibió el santo viático y extremaunción. Tenía otorgado testamento en 20 días del mes de agosto de 1791 ante don Nicolás Bernués. Y dejó heredero a su hijo don Juan Alfranca y Castellote, oidor en la Real Audiencia de Cáceres. Y ejecutores a don José Ariño y don Joaquín Langa, sus primos, a don José Broto, [que había estado casado con su hija], al doctor don José Lassala, al doctor don Tomás Muñoz, canónigo de la misma de Zaragoza, a don Juan Muñoz, beneficiado de la de San Pablo y a don Clemente Tarazona. Y por ser así, lo firmo, Juan Ibáñez, vicario de San Nicolás» ${ }^{148}$.

\section{DOCUMENTOS RELACIONADOS CON EL ALFRANCA, MAGISTRADO}

\section{Problemas de Alfranca con las autoridades de Castuera, patria de Godoy. 12 de mayo de $1794^{149}$}

«Don Manuel Antonio de la Peña, secretario del Acuerdo de la Audiencia del rey nuestro señor, que reside en la villa de Cáceres certifico que en el Ordinario celebrado este día de la fecha se dio cuenta de una Real Orden que pasó el $\mathrm{Sr}$. regente cuyo tenor es como se sigue.

Orden: «En vista de una representación de D. Juan José de Alfranca, oidor de esa Real Audiencia, acerca de la queja que dieron contra él [Alfranca], don Simón Fernández Daza, alcalde de la Villa de Castuera, el año anterior, el escribano Juan Antonio Martínez Matamoros y Juan Caballero Tena, de resultas de haber cortado dicho ministro, en virtud de la real comisión de leva, que se le encargó, varias causas pendientes en el juzgado de dicha villa de Castuera entre Juan Caballero y Miguel Sánchez Ciudad, y su yerno don José de Tena Moya, la mujer y madre de dicho Juan Caballero, sobre injurias verbales y reales, ha-

\footnotetext{
146 Archivo Diocesano de Zaragoza. Parroquia de San Nicolás de Bari. Libro de muertos (17871859). Año 1797, f. 404v.

147 Tomás de Arias también había sido colegial en el Colegio de España de Bolonia.

148 Archivo Diocesano de Zaragoza. Parroquia de San Nicolás de Bari. Libro de muertos (17871859). Año 1797, f. 404v.

149 Archivo Histórico Provincial de CÁCeres, Audiencia, caja 228, expediente 22. 
biendo condenado entre otros a [Fernández] Daza a poner a su costa dos reclutas para el ejército, y a Matamoros y Caballero un recluta cada uno, con varios apercibimientos por las causas que resultaron en los autos contra ellos y expresa Juan José Alfranca, enterado el rey de todo, y satisfecho de la conducta y procedimientos de dicho ministro, ha venido en resolver que se lleven a efecto sus providencias sobre este asunto en todas sus partes, moderándolas solamente en que el don Simón Fernández Daza ponga un hombre solo en lugar de los dos en que le condenó, como así se lo prevengo de Real Orden con esta misma fecha para su cumplimiento en la parte que le toca. Que vuestra señoría haga comparecer a Fernández Daza y se le dé una severa represión por las expresiones libres e indecorosas con que ha tratado en su recurso a un ministro de su majestad, y que esa Audiencia esté a la mira para procurar se extingan los bandos y enemistades en Castuera, corrigiendo a los que de cualquier modo las fomenten.

Todo lo cual prevengo a vuestra señoría de orden de su majestad para su inteligencia y cumplimiento en la parte que le toca.

Dios guarde a vuestra señoría muchos años.

Aranjuez, 3 de mayo de 1794.

Eugenio de Llaguno [El ministro de Gracia y justicia].

Sr. D. Arias Mon.

Es copia de su original que devuelvo al Sr. regente.

Cáceres y mayo, 12 de 1794.

Manuel Antonio de la Peña»150.

\section{Nombramiento del sustituto al defenestrado Alfranca. Aranjuez, 4 de marzo de 1799151}

«El rey. Por cuanto por resolución, a consulta de mi Consejo Real pleno de 21 de octubre de 1784, mandó el rey mi padre y señor (que Santa gloria haya) crear una Audiencia para la provincia de Extremadura con residencia fija en la villa de Cáceres, compuesta por entonces de un regente y ocho ministros, cuatro para lo civil y cuatro para lo criminal, y de un fiscal, gobernándose por las ordenanzas de mi Audiencia y Chancillería que reside en la ciudad de Valladolid $[\ldots]$.

Después, yo, por resolución a otra consulta de mi Consejo de la Cámara de 23 de febrero de 1795, vine en establecer y aumentar una quinta plaza de oidor

150 Archivo Histórico Provincial de CÁceres, Audiencia, caja 228, expediente 22.

151 Archivo Histórico Provincial de CÁcERes, Audiencia, caja 229, expediente 1. 
de la referida mi Audiencia de Extremadura, suprimiendo el corregimiento político y de vara de alcalde mayor de la expresada villa de Cáceres, facilitándose, por este medio, la formación en dicho tribunal de dos salas de lo civil y recayendo así la administración de justicia al cargo de los cuatro alcaldes del crimen en todas las causas civiles y criminales en primera instancia, como antes lo hacía el corregido y alcalde mayor, y encargándose a uno de los cinco oidores de la Audiencia, dotada de dicha quinta plaza con los mismos 18.000 reales de vellón de dotación que tienen los demás oidores, señalados los 5876 reales que gozaba de sueldo del corregidor sobre el fondo de propios de dicha villa de Cáceres, otros 3229 que disfrutaba, asimismo, de sueldo el alcalde mayor; otros 1100 reales que se calculó valdría en arrendamiento la casa propia de la Villa que siempre estuvo destinada para habitación del corregidor, cuya finca debería administrar la Junta de propios, como las demás de su pertenencia; y los 7795 reales de dotación de los demás oidores suplidos del caudal de penas de Cámara, aplicando a este ramo la parte correspondiese al juez en el de denuncias.

Y asimismo, por mi Real Orden 7 de febrero próximo [1799] comunicada al citado mi Consejo de la Cámara por don José Antonio Caballero, mi secretario de Estado y del despacho de Gracia y Justicia, he resuelto que en la citada mi Audiencia de Cáceres se establezca un gobernador de la Sala del crimen de la misma, como lo hay en las demás Chancillerías y Audiencias del Reino, sustituyendo la quinta raza de oidor que tuve por conveniente crear cuando suprimí el corregimiento de dicha en Villa de Cáceres, que he mandado restablecer ${ }^{152}$.

Y últimamente, habiendo tenido por conveniente separar de su plaza de ministro de la citada mi Audiencia de Extremadura a don Juan José de Alfranca y Castellote, por decreto señalado de mi real mano de 4 del propio mes de febrero de 1799, nombré para ella, a vos don Benito Arias de Prada, alcalde del crimen más antiguo de dicho tribunal.

Por tanto, confiando de vuestra suficiencia y fidelidad y letras, y entendiendo que así conviene a mi servicio y a la mejor administración de justicia, mi voluntad es elegiros y nombrados, como por la presente os elijo y nombro para la expresada quinta plaza de ministro de lo civil de la nominada mi audiencia de Extremadura, en lugar y por separación del citado don Juan José de Alfranca y Castellote.

Y mando al regente y demás oidores de ella reciba de vos en persona el juramento y solemnidad que se acostumbra, el cual, así hecho, quiero y mando que, por el tiempo de mi voluntad, podáis oír, librar y determinar los pleitos y causas civiles que ocurran en dicha mi Audiencia, conforme a las ordenanzas de la otra mi Audiencia y Chancillería que reside en la ciudad de Valladolid, en lo que fueren acomodables a su constitución.

152 Archivo Histórico Provincial de CÁceres, Audiencia, caja 229, expediente 1, f. 59v.

Hispania Sacra, LXI

123, enero-junio 2009, 279-352, ISSN: 0018-215-X 
Que os hayan y tengan por uno de los cinco ministros de lo civil de la referida mi Audiencia territorial.

Y es mi merced que hagáis y llevéis de salario en cada un año los mismos 18.000 reales de vellón que los demás ministros de lo civil de dicha mi Audiencia, satisfechos los 10.205 del caudal de propios de la citada villa, y los restantes 7795 , del caudal de penas de Cámara, según lo tengo resuelto y va referido, desde el día en que empezareis a servir este empleo, prorrata hasta fin del año y de allí adelante enteramente en cada uno de los siguientes, todo el tiempo que sirviereis dicha plaza hasta que por vuestra antigüedad os corresponda optar al goce de los mismos 18.000 reales que se pagan por mi Real Erario [como estaba recibiendo Alfranca], sin el descuento antiguo de $10 \%$

[...]

Aranjuez, a 4 de marzo de 1799. Yo, el rey. Por mandato del rey nuestro señor, Sebastián Piñuela»153.

Documentos relacionados con el Alfranca, CANÓnigo doctoral DE TeRUEL (1810-1817)

\section{Oposición a la canonjía doctoral de Teruel, ganada por Alfranca. No- viembre de $1810^{154}$}

«Día 26 [de noviembre de 1810]. Cabildo de palabra en la sacristía en el que hicieron presente los señores comisionados para los ejercicios en la oposición para la provisión de la actual doctoral, vacante, que, concluidos los términos de los edictos y los de gracia, sólo habían concurrido dos opositores, y, por consiguiente, que el cabildo dispusiera lo conveniente para el segundo argumento; y en su vista los señores Becerril y Calvo se prestaron voluntariamente a argüir cada uno a cada uno de los opositores. Arguyó Becerril al opositor Alfranca y el señor Calvo al opositor García, lo que se pusiese en noticia de dichos opositores para su inteligencia y remisión de conclusiones a dicho señores, lo cual así se practicó. Dr. Rubio, pro secretario [rúbrica].

En el día 3 del mes de diciembre, cabildo extraordinario convocado con cédula ante diem por el Sr. Lalana, presidente, para la aprobación o lo que haya lugar de los ejercicios literarios que han hechos los doctores don Juan Josef Alfranca y don Domingo García, únicos opositores que han concurrido para la doctoral vacante, a cuyo cabildo asistieron los Sres. Lalana, presidente,

153 Archivo Histórico Provincial de CÁCeres, Audiencia, caja 229, expediente 1, f. $61 \mathrm{v}$.

${ }^{154}$ ACT, Libro de Actas del Cabildo, tomo VI, ff. 301v-303r. 
arcediano, arcipreste, tesorero, chantre, Agustín, magistral, Pretel, Redondo, Becerril, Calvo y el infraescrito secretario. Hecha relación por Benito García, pertiguero, de hacer convocado a todos los señores, propuso dicho señor presidente que, respecto de haberse concluido dichos ejercicios literarios, se procediese a su aprobación, o a lo que hubiese lugar, y al señalamiento del día para la elección, teniendo presentes las circunstancias actuales de estar amenazada esta ciudad de invasión del ejército francés; y oído por dichos señores, todos unánimes y ninguno discrepante, aprobaron los ejercicios literarios de los citados dos únicos opositores y señalaron para la elección de doctoral el día 4 de este propio mes [diciembre 1810], dando de todo noticia a su ilustrísima mediante carta, dirigiéndola a Sarrión o donde se halle, como así se ejecutó en este mismo día, y se leyeron los méritos particulares de dichos opositores. Enseguida se mando entrar al escribano Juan Gabarda con testigos, y le manifestó el Sr. presidente que el cabildo unánimemente había aprobado los ejercicios literarios de los dos opositores, y señalado parada elección de doctoral el día 4 de este mismo mes.

Se leyó una carta del ilustrísimo señor obispo, su fecha en la Jaquesa, a 25 de noviembre, en la que expresa su ilustrísima que queda enterado de cuanto el cabildo le decía en la suya de 22 del propio mes, en orden a la oposición de la [canonjía] doctoral.

También se leyó una carta del Supremo Consejo de Regencia, de 31 de octubre [1810] que se recibió el 28 de noviembre, en la que se insertan los Decretos de nombramiento de los tres señores que las Cortes generales han nombrado para que compongan dicho Consejo de Regencia. Doctor Juan Vicente Rubio y Musoles, pro secretario [rúbrica]» ${ }^{155}$.

\section{Cabildo extraordinario del 4 de diciembre de 1810, en el que se eligió canónigo doctoral a Alfranca}

«En el día 4 del mismo mes [diciembre 1810] cabildo extraordinario, convocado con cédula ante diem, al que asistieron los Sres. Lalana, presidente, arcedíano, arcipreste, tesorero, chantre, Agustín, magistral, Pretel, Redondo, Becerril, Calvo y el infraescrito secretario; y no asistieron el ilustrísimo señor obispo, señores Sacristán [Fernando Luengo], Ugarte ni penitenciario, por estar ausentes. Hecha relación por el pertiguero, Benito García, de haber convocado a todos los señores, el señor Becerril presentó poderes que otorgó a su favor el Sr. Íñigo, que padece el accidente de la privación de la visita. Y habiéndose leído, se encontraron estar conformes dichos poderes. Enseguida se hizo por cada

155 ACT, Libro de Actas del Cabildo, tomo VI, f. 301v.

Hispania Sacra, LXI

123, enero-junio 2009, 279-352, ISSN: 0018-215-X 
uno de dichos señores el juramento que previenen los estatutos del modo que se expresa en las otras elecciones. Así ejecutado, se procedió a la elección para cuyo efecto se presentó una arquilla en la que, y sobre los cajoncillos oportunos, se hallaban escritos los apellidos de los dos únicos opositores que han concurrido, lo cual se puso también de manifiesto al escribano Juan Gabarda, que se le hizo entrar con los testigos; y habiéndose retirado se pasó a la votación, votando cada uno de los señores por sí y el señor Becerril, además, por el Sr. Íñigo en virtud de sus poderes.

Concluida la votación se abrieron los cajoncillos y demostró que en el correspondiente a don Juan José Alfranca había nueve votos; en el perteneciente al don Domingo García, tres votos; y un voto en cajón vacío. En su vista se mandó entrar al escribano Juan Gabarda y a su presencia y de los testigos declaró el señor presidente que, hecha la votación, había sido electo canónicamente don Juan José Alfranca para el canonicato doctoral vacante, y mandó al pertiguero Benito García pasase a hacérselo saber a dicho Alfranca para su aceptación. Y habiéndose así verificado, se presentó en aula capitular y declarando su aceptación y hecho por el mismo el acostumbrado juramento de guardar los estatutos, pagar media anata y el 5\%, pasó dicho don Juan José Alfranca con el notario y testigos a la residencia del Señor Provisor, para que se sirviese, por ausencia de su ilustrísima, conferirle la institución canónica de dicho canónicato doctoral, habiendo expuesto el encargado de la cobranza de las anualidades estar asegurado su pago. Posteriormente se presentó en aula capitular don Juan José Alfranca con el notario y testigos y expuso que el señor provisor le había conferido la instrucción canónica de dicho canonicato doctoral, por lo que dicho Alfranca hizo la profesión de fe y, enseguida, pasó a tomar la posesión de su canonicato doctoral, habiéndolo acompañado los señores chantre y Becerril. Y casi ejecutado, expresó el notario que la había tomado quieta y pacíficamente y se procedió al osculum pacis y se le señaló para cantar el evangelio, por ser diaconil, el día inmediato cinco y siguientes.

Los gastos de posesión son los mismos que resultan al folio 132 vuelto.

Doctor Juan Vicente Rubio y Musoles [rúbrica] pro secretario.

Nota al margen. El nuevo doctoral cantó el evangelio el día 5 de diciembre siguiente a su elección en la misa conventual que celebró el señor arcipreste semanero, sirviendo de subdiácono el señor Becerril [rúbrica]» ${ }^{156}$.

156 ACT, Libro de Actas del Cabildo, tomo VI, f. 303r. 


\section{Alfranca es elegido gobernador eclesiástico de la diócesis de Teruel. 12 de febrero de 1811. Notario D. Juan Gabarda ${ }^{157}$}

«En la ciudad de Teruel, a 12 días del mes de febrero del año contado del nacimiento de nuestro Señor Jesucristo de 1811.

[Después de leer las letras del obispo Álvarez, textualmente se dice]:

Y en vista de las referidas letras el dicho Ilmo. cabildo aceptaba y aceptó el gobierno de esta dicha ciudad y diócesis y administración general de los bienes de su señoría en la forma que en aquellas [letras] se contiene, y para la mayor facilidad de desempeñar los negocios que pertenecen a uno y otro objeto designaba la persona que ha de ejercer el gobierno del obispado en lo espiritual y temporal y la administración general de los bienes de la mitra en la del Dr. don Juan José de Alfranca y Castellote, canónigo doctoral de esta santa iglesia, quedando éste por esta designación en el ejercicio de toda la autoridad, jurisdicción y facultades que se contienen en las letras de su ilustrísima refiriéndolas todas el Ilmo. cabildo a su persona. Que declaraba y declaró igualmente que el Dr. D. Braulio Ángelo Feliú continué, por ahora, en ejercicio y jurisdicción que su Ilma. le tenía concedida en calidad de provisor y vicario general interino, a cuyo efecto haya de presentar las letras que al efecto tenga de su ilustrísima al expresado señor gobernador designado, reconociéndolo por tal gobernador y esperando de su prudencia y obligaciones la mayor armonía con dicho gobernador y la debida sujeción a sus órdenes, mientras se mantenga en ejercicio del provisorato interino.

Y mandaba también el nominado ilustrísimo cabildo que don Antonio Marco de Coley seguirá ejerciendo la notaría mayor de la curia eclesiástica y entienda en los asuntos que señala su ilustrísima en sus arriba insertas «Letras»; y que en cuanto a los demás oficios y empleos propios del gobierno y curia, provea el Sr. gobernador designado según tuviere por conveniente; y en los que juzgare necesitar la intervención del cabildo, éste proveerá lo conveniente, según las ocurrencias; y que este acto se notifique a todos los individuos de la curia, casa de su ilustrísima para su inteligencia, gobierno y obediencia y enseguida al clero del obispado y demás cuerpos y personas que corresponda, cuya designación de gobernador había ejecutado el Ilmo. cabildo por votos secretos.

Y para que surta los efectos convenientes, el referido ilustrísimo cabildo me requirió hiciese y testificase acto público; y en exoneración de mi oficio, yo el notario hice y testifiqué el presente, uno y muchos y tantos cuantos en derecho sean necesarios» 158 .

157 ArChivó Histórico Provincial De Teruel, protocolos del notario Juan Gabarda, legajo número 438 (año 1811), ff.9r-12r.

158 ArChivó Histórico Provincial De Teruel, protocolos del notario Juan Gabarda, legajo número 438 (año 1811), ff.11r-12r.

Hispania Sacra, LXI

123, enero-junio 2009, 279-352, ISSN: 0018-215-X 


\section{Carta recriminatoria del obispo de Teruel al gobernador Alfranca, Pego (Alicante), 29 de marzo de $1811^{159}$}

«Ilmo. Sr.:

Todas mis confianza y facultades puse en Vuestra Señoría Ilustrísima, y de las que es muy responsable a Dios y a la iglesia de todo. Las diócesis inmediatas me avisan de un modo que me contrista la adhesión de vuestra señoría Ilustrísima a cuanto los enemigos no sólo mandan sino idean y aún se les atiza. Desengáñeme vuestra señoría Ilustrísima pronto, porque debo obrar antes que los enemigos dejen mi capital, que será muy cercano.

Dios me guarde a vuestra señorial Ilustrísima muchos años como le ruega su sincero y cordial Blas Joaquín Álvarez de Palma.

Pego, 29 de marzo de 1811.

Ilmo. Sr. presidente y cabildo de la Santa iglesia de Teruel» 160 .

\section{Vereda del provisor Francisco Calvo Ruipérez, enemigo de Alfranca, en la que anula el concurso de curatos, Teruel, 9 de julio de $1813^{161}$}

«Nos, el doctor don Francisco Calvo Ruypérez, presbítero, arcipreste de la Villa de Baltanás, provisor y vicario general eclesiástico de la diócesis de Teruel, reconocido como tal por el gobierno legítimo de España, etcétera.

A los señores rectores, curas y regentes legítimos del obispado de Teruel salud y gracia en nombre de nuestro Señor Jesucristo.

Hallándonos bien penetrado y convencido plenamente de la violencia con que se exigió en esta diócesis el juramento de fidelidad a la Constitución francesa, sin que haya memoria de haber ocurrido en toda la península otro ejemplar más estrepitoso y escandaloso; y constándonos igualmente que ningún eclesiástico secular y regular le prestó por escrito desde el pueblo de su residencia sin precaverse y asegurarse de antemano con las protestas y restricciones más religiosas, no menos que conformes a las tristes circunstancias que mediaban en aquella terrible y espantosa época; como lo confirma el heroísmo y política observada por los muy ilustres capitulares eclesiásticos de Teruel, Cella y otros, a pesar de verse confundidos, oprimidos y amenazados de bayonetas ene-

\footnotetext{
159 ACT, 228-19-1, y Actas, fol. 320. César Tomás Laguía, «La Iglesia de Teruel en la Guerra de la Independencia», en Revista de Teruel, n. ${ }^{\circ} 21$, Teruel, 1959, p. 171-172.

${ }^{160}$ ACT, 228-19-1, y Actas, fol. 320. César Tomás Laguía, «La Iglesia de Teruel en la Guerra de la Independencia», en Revista de Teruel, n. ${ }^{\circ} 21$, Teruel, 1959, p. 171-172.

161 AHDT, Leg. 98-4, ff. 87-90.
} 
migas, y presidido aquel por el ejecutor [Alfranca] de tan inaudito y execrable crimen, reclaramos, para la tranquilidad pública y sosiego espiritual de toda la diócesis, ser dicho juramento, hecho por escrito, una simple y mera fórmula, sin obligación ni fuerza alguna en el fuero interno y espiritual, dictada por don Juan de alfranca, llevado de su egoísmo e ideas fanáticas, con el único fin de hacerse, por medio de estas y otras exterioridades, igualmente violentas, buen lugar con el gobierno intruso.

Por cuyo motivo solamente aquellos eclesiásticos seculares y regulares que libre y espontáneamente se presentaron al referido Alfranca y en sus manos juraron obedecer las máximas y doctrinas contenidas en el código de Napoleón, conducidos de fines serviles e intereses personales, cuales nos consta fueron sacar licencias, obtener recompensas u otros menos honestos y lícitos, quedan ipso facto privados de cualesquiera gracias que aquél les hubiese dispensado y suspensos de las funciones presbiteriales en toda su extensión hasta que se retracten y den una satisfacción pública de su crimen de infidencia y abjuraren su error a presencia de sus superiores eclesiásticos, de quienes por fines serviles huyeron teniéndolos tan próximos e inmediatos, con riesgo inminente de sus personas, y sin otro objeto que el de impedir un cisma.

Con arreglo a lo sancionado sabiamente por el artículo 24, título II de la Constitución política de la nación española [la de Cádiz], declaramos suspensos ipso facto del ejercicio presbiterial por espacio de cuatro meses a los eclesiásticos seculares y regulares que, habiendo hecho oposición en el último concurso, firmaron a las vacantes de patronato y presentación real, y habiendo obtenido títulos y despachos formales del gobierno intruso, sostenidos y auxiliados de su fuerza sanguinaria tomaron libre y voluntariamente la colación canónica; por haber perdido, en el mismo hecho de admitir destino u empleo de aquel gobierno, la calidad y condición de ciudadanos; hasta que el legítimo [gobierno] de nuestra nación los exonere de su crimen de infidencia, calificado y justificado plenamente con el modo violento y porte estrepitoso de que se valieron los agraciados, y les conceda de nuevo el derecho y goce de ciudadanos. Todo sin perjuicio de purificar su escandalosa conducta e ideas ambiciosas por lo que respecta a la jurisdicción eclesiástica, que legítimamente ejercemos.

Quedan ipso facto suspensos del ejercicio sacerdotal, por espacio de seis meses y privados de desempeñar en esta diócesis funciones parroquiales, los regulares que, sin habilitación expresa de su actividad, hayan recibido colación canónica de cualesquiera títulos perpetuos, a causa de haber apostatado, llevados de un interés sórdido y vil, de los votos solemnes e indisolubles con que libremente se ligaron en sus sagradas profesiones religiosas, fomentando con esta política y conducta anti evangélica un cisma devorador que cortó el cielo para nuestro consuelo, sepultando en un profundo olvido al promotor [Alfranca] de tan detestable y afrancesada filosofía, debiendo, contra todos sus senti- 
mientos, confesar, estos falsos profetas y agoreros de los proyectos e ideas ambiciosas de Napoleón, que las calamidades y desgracias en que hace sólo cinco años se ve envuelta nuestra constante invicta e inmortal nación española con admiración de Europa y asombro de todo el universo, no han podido autorizar opiniones tan contrarias diametralmente al espíritu del Evangelio, destructoras de los principios más fundamentales, sabios e irrefragables de nuestra única y santa religión católica, apostólica, romana. E igualmente están obligados a publicar desde la cátedra del Espíritu Santo (si llegan a hacerse dignos devolverla a ocupar) que no ha sido capaz nuestra envidiada y sagrada revolución ni la confusión y trastorno que ha experimentado nuestra nación, fiel sin ejemplar a nuestro legítimo soberano cautivo, de autorizar a un simple presbítero [Alfranca] para usurpar a la cabeza visible de la iglesia una potestad que, dimanando de nuestro Señor Jesucristo, le es privativa y peculiar por ser su único e inmediato Vicario. Sin que otra jurisdicción sagrada la pueda ejercer, ni haya memoria de haberla ejercido aún en los siglos más bárbaros y corrompidos de la era cristiana con el desprecio que lo ejecutó en medio de las bayonetas francesas el corifeo e iluminador de estos maquiavelistas [Alfranca], escudado y apoyado en alguna disciplina eclesiástica que habrá enseñado secretamente a sus prosélitos, y se reservará publicar si variarían las circunstancias, para ilustrar a nuestro siglo ignorante, disipando con un trabajo antisocial las tinieblas e idiotismos en que yacíamos soporados y aletargados vuestros superiores eclesiásticos, como os lo manifestaría no pocas veces en sus conversaciones familiares, cuando no se ocultó de indicároslo en sus veredas reformadoras. ¡Qué días tan felices no se prometerían estos espíritus fuertes, si el cielo no les hubiera cortado el hilo de sus futuras esperanzas y a Bonaparte, oscurecido sus gloriosas conquistas indefinibles e interminables!.

Finalmente, quedan suspensas todas las licencias de celebrar, confesar y predicar dadas en Teruel desde el día 19 de enero del año 1811, no estando posteriormente confirmadas por este ordinario diocesano o por nos; sin fuerza los títulos y despachos librados en esta época para tomar posesión de rectorías, curatos, beneficios y regencias de cualesquiera naturaleza que sean; anuladas las reducciones de misas con obligación de avisarnos inmediatamente los agraciados de las que les restan descargar, para disponer su pronta celebración; y finalmente quedan sin vigor las dismembraciones de títulos eclesiásticos unidos, precedida sentencia definitiva para su colación y posesión real, por ser los únicos estimulantes y alicientes que han arrastrado a la infidencia en estos días de desorden y confusión a algunos eclesiásticos, tanto seculares como regulares de esta diócesis, y servido de premio para aumentar el número de chendarmes $^{162}$

162 Galicismo, derivado de la palabra gendarme («hombre de armas»), Los «Chendarmes» era un cuerpo mixto de gendarmes, a pie y a caballo, al mando de un comandante francés, que se demostraron eficacísimos en su lucha antiguerrillera. Se dieron fundamentalmente en la zona controlada por Suchet, es decir en el antiguo Reino de Aragón. 
de la iglesia, en expresión del pueblo, hasta autorizarse estos egoístas por sí mismos, para adjudicarse las regencias y rectorías de término de este obispado, sin tener a su favor otros méritos que el general desprecio de sus virtuosos y fieles hermanos y el adormecimiento execrable aun de los españoles espurios y afrancesados; ya que por su idoneidad, calidad y principios filosóficos no se podían estos neófitos juzgar beneméritos y dignos de semejantes ascensos, como consta en el obispado, a no haber sido sostenidos por otro tan alucinado y fanático [Alfranca] como ellos.

Los rectores, curas y regentes legítimos de la diócesis, y en su defecto el presbítero más antiguo, notificarán en las sacristías de sus respectivas iglesias el contenido de esta vereda a los eclesiásticos seculares y regulares domiciliados y agregados existentes en sus parroquias, quedando todos en general y cada uno en particular obligados bajo de iguales suspensiones a darnos inmediatamente parte de los individuos que, hallándose comprendidos en las censuras y declaraciones que quedan hechas e impuestas, no se conduzcan con tales, a fin de proceder contra su inobediencia con la mayor severidad hasta auxiliarnos del brazo secular en caso necesario, para reprimir su obstinación e inflexibilidad.

Se copiará literalmente en los libros de acuerdos parroquiales y, en su defecto en los cinco libros, bajo la pena de suspensión, la circular para que en todos tiempos sirva de satisfacción a los eclesiásticos de esta diócesis, que en unas circunstancias tan destructoras no se han dejado llevar, y menos pervertir, de la filosofía moderna y sus sectarios, habiéndose mantenido con fortaleza de espíritu sumisos a sus superiores, dando a un tiempo las pruebas más sinceras e irrefragables de su respeto y sumisión a la Santa Iglesia católica apostólica romana, y a su nación el testimonio más auténtico de su fidelidad y amor.

Los párrocos no estando imposibilitados, y en su defecto el eclesiástico que cada uno depute, pasará personalmente a entregar de inmediato esta circular, tomando para su seguridad el correspondiente recibo, para convenir así al bien espiritual del obispado, quedando a nuestro cargo hacer presente a la Regencia del Reino este y otros servicios que inmortalizarán la conducta observada por el clero de esta diócesis.

Teruel y julio, 9 de 1813 .

El doctor don Francisco Calvo Ruipérez, provisor y vicario general [rúbrica]» 163

163 AHDT, Leg. 98-4, f. 88v.

Hispania Sacra, LXI

123, enero-junio 2009, 279-352, ISSN: 0018-215-X 


\section{Instancia de Juan José Alfranca, canónigo de Teruel, en la que pide se le devuelvan algunos bienes perdidos durante el secuestro. Noviembre de $1813^{164}$}

«Don Fernando VII, por la gracia de Dios y por la Constitución de la Monarquía española rey de las Española y, en su ausencia y cautividad, la Regencia del Reino nombrada por las Cortes Generales y Extraordinarias,

A vos, cualesquiere de nuestros escribanos públicos y reales de la presente Provincia de Aragón, salud y gracia, sabed:

Que por procurador legítimo de don Juan José Alfranca, canónigo doctoral de Teruel, en el expediente que abajo se expresará, se pareció en el recurso del tenor siguiente:

[Recurso]

«Excelentísimo Sr.:

Mariano Sebastián, en nombre don Juan José de Alfranca, canónigo doctoral de Teruel, en el expediente sobre ocupación de los bienes de mi parte por el comisionado de la Hacienda Pública en dicha ciudad, ante vuestra excelencia, como mejor proceda, DIGO:

Que a consecuencia de haber pasado a este tribunal el caballero intendente el expediente instado por mi parte contra el ilegítimo secuestro de los efectos de su casa de Teruel, se sirvió vuestra excelencia mandar, en 13 de septiembre último, se entregase a mi parte o persona que deputase todo lo secuestrado. Para lo que se libró el mismo día [13 de septiembre de 1813] el correspondiente despacho, que, cumplimentado por el juez de primera instancia, se hizo saber a Don Benito Pereda, principal comisionado de la Hacienda Nacional, en el día 22. Y por don Joaquín Lerena, otro de ellos por quien se practicó el secuestro, se entregaron la mayor parte de los efectos, y no pocos de ellos disminuidos o deteriorados, por cuanto no estuvieron en un depósito riguroso y legal, como será [sic, se hará] constar si fuere necesario.

Mi principal llama en el día la atención del tribunal sobre el contenido del testimonio que con debida solemnidad presentó, del que resulta que doña Juana Terán, baronesa de Escriche, recurrió en 28 de julio [de 1813] al caballero Intendente desentendiéndose de su marido el Barón, residente en Teruel o en su inmediata Baronía de Escriche, que es a quién correspondía hacerlo como cabeza de la casa, suponiendo que, entre las prendas secuestradas en Teruel, había

164 ARChIVO Histórico Provincial de ZARAGOZA, Índice del libro único de registro de provisiones civiles expedidas por la Real Audiencia de Aragón desde el día 20 de agosto del año de 1813 hasta últimos del mismo año. Conocido como Libro de Reales Provisiones, ff. 66r-69r. 
mucha porción de ropa suya, vendida allí por los franceses y comprada por las personas que habían sufrido el secuestro, sin expresar quiénes eran éstas ni las prendas de su pertenencia, y, ponderando ser una de las que más habían perdido durante la permanencia de los franceses, pidió se le devolviesen.

$\mathrm{Y}$ aunque el decreto genérico y provisional del caballero intendente de 30 del mismo mes [julio de 1813] no mandó especialmente que se le entregasen efectos algunos, sino en general los que se reclamasen de los que estuviesen bajo la inspección del comisionado, tomando antes los conocimientos oportunos y constándole de la verdad del recurso y de la identidad de los efectos reclamados, la baronesa ha recibido de mano del comisionado Lerena los [bienes] secuestrados de mi parte: seis cortinas de Damasco de seda carmesí con cordones y borlas de lo mismo, tres toallas de manteles, dos toallas, diecisiete servilletas (once finas y seis bastas), tres de las cuales, dice la baronesa en su recibo, tenían por marca una «J», de que resulta que en la entrega de los efectos de mi parte, que vuestra excelencia mandó se le hiciese en su totalidad, se han excluido dichas ropas que, como quiera, importan bastante dinero y se utiliza de ella la baronesa.

Bien se comprende los pocos conocimientos que habrá tomado el comisionado de la Hacienda Nacional cuando ha hecho la entrega sin entenderse en nada con el apoderado de mi parte, a quien tenía dado recibo testimoniado de lo secuestrado. Y cuán poco se habrá fatigado la baronesa en acreditar la identidad cuando ella misma confiesa que la entrega se le ha hecho porque ha reconocido dichos defectos como suyos, y, según se ve, se le han dado los que ha querido tomarse bajo su palabra, cerca de dos meses después del Decreto inconcreto [de 30 de junio de 1813] que obtuvo del caballero intendente después de expedida la Provisión de vuestra excelencia y cuando ya no estaban a la inspección del comisionado, ni éste podía por sí proceder a entrega alguna, habiéndole mandado el intendente, a consecuencia del Decreto de 11 de agosto [de 1813], que consta al folio 16 del expediente, que tuviese los bienes ocupados en calidad de pertenecientes a mi principal y a disposición de este superior tribunal [Audiencia Territorial de Zaragoza], sin cuya anuencia no pudo hacer entrega alguna, porque el Decreto obtenido por la baronesa debió quedar suspenso por la citada orden posterior, comunicada al comisionado.

Ni la marca «J», encontrada en tres de las servilletas puede autorizar a la baronesa o ocuparlas como suyas, porque se llama «Juana», llamándose «Juan», igualmente mi principal; pues sobre que las ropas de uso común de la casa del marido no es regular estén marcadas con la inicial del nombre de la mujer, si pretende que, por dicha marca ambigua, son suyas dichas servilletas, no deberán serlo de su pertenencia las cortinas de seda y demás piezas que no expresa tengan tal marca, y así no han debido entregársele, y menos no costando ni expresándose en el recibo que haya acreditado la identidad de ellas en la forma 
correspondiente, porque, si esto se permitiese, podría la baronesa equipar enteramente la casa de su marido a pretexto del baúl que publicó le habían robado los franceses en una de las masadas de la Baronía de Escriche, desacreditando impunemente por este medio a las gentes de honor con la tacha de que habían comprado de los franceses efectos robados a ella. Lo que, aunque hayan quizá hecho algunos a quienes la baronesa sacó varias ropas con dicho título, valiéndose de la autoridad francesa, mi principal no es sujeto capaz de adquirir por este ruin medio, por más que [a] la baronesa se [le] haga lícito, porque lo ve desgraciado y preso, de ajar su honor y delicadeza, que le interesa conservar tanto por lo menos como pueda interesarle la suya a la misma [baronesa].

Esta injuria es mucho más sensible a mi principal que lo sería la pérdida de los efectos que sin razón se ha apropiado la baronesa a la sombra del decidido favor que le han dispensado los comisionados, y mi principal confundirá las ideas que se traslucen en esta conducta, haciendo constar, a su tiempo, que las seis cortinas que Damasco de que se trata estuvieron en uso de la casa que habitaban los padres de mi principal en esta ciudad [Zaragoza], calle Gabín, hasta fines de 1788, y que las mismas, con las demás ropas ocupadas por la baronesa, han formado, desde dicha época, parte de su equipaje en Sevilla, Cáceres y otras partes donde ha residido.

Esto no es más que dar al tribunal una idea de este negocio, porque para este recurso parece basta que vuestra excelencia haya mandado se entreguen a mi parte todos los bienes y efectos que se le secuestraron, que en dicho secuestro se hallen comprendidos los expresados efectos y que ahora no le hayan devuelto, para que desde luego se le restituyan como está mandado, do cualquiera parte que existan.

Por tanto, a vuestra excelencia suplico que, a consecuencia de lo mandado en su auto de 13 de septiembre último, se sirva expedir su Provisión, a costas de quien haya lugar, para que los comisionados de la Hacienda Nacional de Teruel, recogiendo inmediatamente de poder de la baronesa de Escriche o de cualquier otra persona en quien existan las seis cortina de seda de Damasco carmesí con sus cordones y borlas, las tres tallas de manteles, dos toallas y 16 servilletas bastas y finas que han faltado de la restitución mandada de los efectos secuestrados a mi parte y resultan del testimonio del escribano Gabarda, que suplico haya vuestra excelencia por presentado, se entreguen ante todas cosas a mi principal o su procurador en Teruel, y que si, ejecutado así, la baronesa u otro cualquiera tiene que exponer, lo haga en este expediente donde está mandada la devolución a mi principal de todo cuanto se le secuestró, pues así procede en Justicia, que oído con costas y para ello, etc. Doctor Juan José Alfranca.

Mariano Sebastián»165.

165 ARChivo Histórico Provincial de ZARAgOZA, Índice del libro único de registro de provisiones civiles expedidas por la Real Audiencia de Aragón desde el día 20 de agosto del año de 1813 hasta últimos del mismo año. Conocido como Libro de Reales Provisiones, f. 69r. 


\section{Representación de Alfranca contra el Obispo y el provisor Calvo Ruipé- rez en el asunto de curatos. 27 de julio de $\mathbf{1 8 1 4}{ }^{166}$}

«Sobre provisión de nueve curatos, cuyo concurso anuló el reverendo obispo de Teruel y formó y convocó otro de nuevo para ello. Se oponen los párrocos que fueron nombrados y el gobernador que fue del obispado.

Del Consejo extinguido de Estado se han remitido a la secretaría de la Cámara en nueve ternas que dirigió el reverendo obispo de Teruel a dicho Consejo en 3 de enero de este año [1814] para otros tantos curatos vacantes en aquella diócesis a la Real provisión, manifestando, en representación que acompañó, los motivos y causas que le movieron para anular el concurso hecho en tiempo de la dominación francesa para de dichos curatos, y del que legítimamente convocó y celebró en fin del próximo pasado de 1813.

Vinieron unidos a este expediente tres representaciones de los párrocos que fueron nombrados en el concurso que se cita anulado, y otra del gobernador que fue de aquel obispado, relativas al mismo concurso (que todo acompaña original) en que solicitan que no se anule por las causas y motivos que difusamente exponen.

El apoderado del obispo ha presentado memorial a la Cámara solicitando se dé curso a dichas nueve ternas.

Madrid, 27 de julio de 1814.

Al Señor Fiscal [rúbrica].

El fiscal lo ha visto y dice: que para poder salir de las dudas y perplejidades que ofrece la oposición diametral de los hechos en que se funda respectivamente el reverendo obispo de Teruel, para calificar la nulidad del concurso celebrado por el gobernador de aquel obispado durante la ausencia del prelado en el mes de mayo de 1812, y dicho gobernador y opositores para pretender que se sostenga y confirme sin dar lugar a las ternas que remite el reverendo obispo por consecuencia del que mandó celebrar en el año próximo pasado de 1813, se hace indispensable en su concepto [el del fiscal], que la Cámara, siendo servida acuerde se diga al reverendo obispo que remita a esta superioridad el expediente formado por el gobernador de aquel obispado [Alfranca] durante su ausencia para el concurso que celebró en el mes de mayo de 1812, y que, venido que sea y unido a este expediente, se dé con él nueva vista al fiscal, que dirá entonces lo que proceda, o resolverá la Cámara como siempre lo más conforme.

Madrid, 20 de agosto de 1814 [rúbrica].

Madrid, 27 de agosto de 1814. Con el señor fiscal»167.

166 AHDT, Leg. 98-4, ff. 1-12.

167 AHDT, Leg. 98-4, ff. 1-12.

Hispania Sacra, LXI

123, enero-junio 2009, 279-352, ISSN: 0018-215-X 


\section{En el cabildo del día 19 de abril de 1817 se da cuenta de que había falle- cido su doctoral Alfranca ${ }^{168}$}

«Día 19 de abril. Cabildo de palabra en la sacristía. Se propuso por el señor deán que, habiendo fallecido el Sr. doctoral, a cuyo cargo estaba la cobranza del subsidio desde junio del año 1815, continuaría hasta formalizar el estado de las cuentas de la cobranza de dicho señor, su heredero Domingo Barquero; y se acordó se le encargue a este mismo lo ejecute a la mayor brevedad hasta que sea nombrado otro señor prebendado con arreglo a las instrucciones de gobierno. Asimismo que el mismo Barquero, encargado de la cobranza del ramo de Mayordomía de la iglesia, sea avisado para la más pronta liquidación de cuentas del año pasado 1816, y que avisado de que esta resolución, Barquero ofreció salir garante a unas y otras con el esmero que sea posible. Pedro Asín, canónigo penitenciario, secretario» ${ }^{169}$.

\section{Biografía de Alfranca según el llamado Libro de Cintas de la catedral de Teruel ${ }^{170}$}

El quinto canónigo doctoral y undécimo de esta prebenda, el doctor don Juan José de Alfranca y Castellote, natural de la ciudad de Zaragoza, doctor en ambos derechos en la universidad de dicha ciudad, en la que sustituyó la cátedra de Prima de Cánones, colegial y después rector por su majestad del Real Colegio Mayor de San Clemente de Bolonia en Italia, en cuya universidad fue catedrático de jurisprudencia, alcalde del crimen de la Real Audiencia de Sevilla y oidor de la de Extremadura desde su creación en 1791, pensionista por su majestad de la mitra de Cartagena, con cuyo título se ordenó de presbítero en las Témporas de Cuaresma de 1807 . Hizo oposición a la doctoral de esta iglesia, vacante por muerte del señor Otaño, la que le confirió el cabildo en 4 de diciembre de 1810, y cantó el evangelio en el día 5 siguiente, oficiando la misa el señor arcipreste, don Santiago Díez. En el 12 de febrero del año siguiente 1811, habiendo el señor obispo don Blas Álvarez de Palma emigrado de esta diócesis por las ocurrencias de la guerra, y expedido sus letras en 5 del mismo mes desde Pego, en el Reino de Valencia, donde residía, nombrando al cabildo y a cada uno de sus individuos por gobernador y administrador general de la mitra con las más amplias facultades, aquel, habiendo de nombrar un prebendado para que ejerciese las funciones de gobernador y administrador general de las rentas de la mitra, designó para ello, precedida votación por escrutinio, a dicho señor

168 ACT, Libro de Actas del Cabildo, tomo VII, f. 94v-95r.

169 ACT, Libro de Actas del Cabildo, tomo VII, f. 94v-95r.

170 ACT, Legajo 105 (vulgarmente Libro de Cintas), f. 192 v, 
doctoral Alfranca, según costa del Libro de gestis y de la acta que levantó el escribano Real Juan Gabarda, en cuyas notas constará este nombramiento; cuyo empleo lo ejerce hoy, 8 de junio de 1812, en que esto se escribe en los tiempos difíciles y circunstancias aparecidas, en que se halla esta ciudad y partido, sin omitir las funciones y obligaciones de la doctoral.

[Letra de otra mano] Murió en 14 de abril de 1817» ${ }^{171}$.

171 ACT, Legajo 105 (vulgarmente Libro de Cintas), f. 192 v.

Hispania Sacra, LXI

123, enero-junio 2009, 279-352, ISSN: 0018-215-X 